JANA ILLIGER

\title{
Sole Guardianship for Permanent Caregivers
}

\author{
DISSERTATION \\ MASTERS OF LAW
}

FACULTY OF LAW

TE WHARE WÁNANGa O TE ŪPOKO O TE IKA A MĀUI

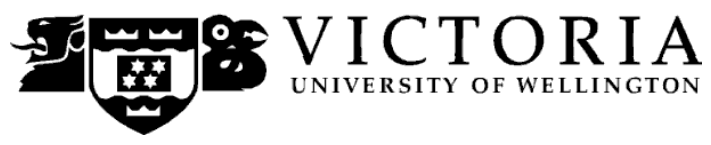

2013 



\section{Contents}

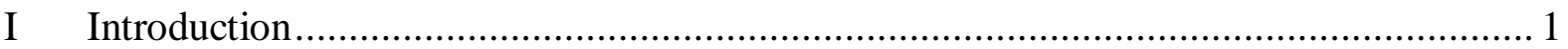

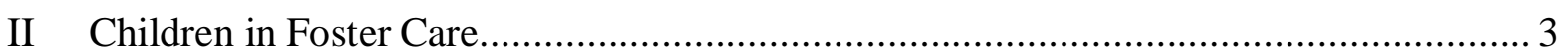

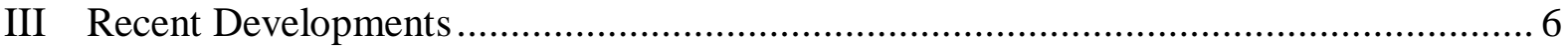

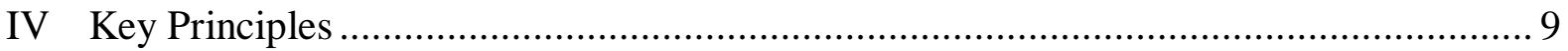

A The Welfare and Best Interests of the Child …….................................................... 9

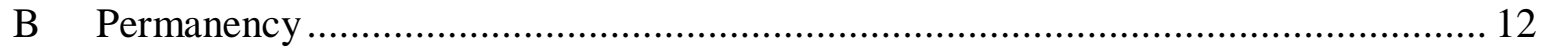

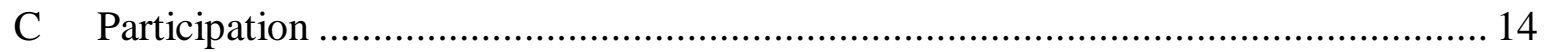

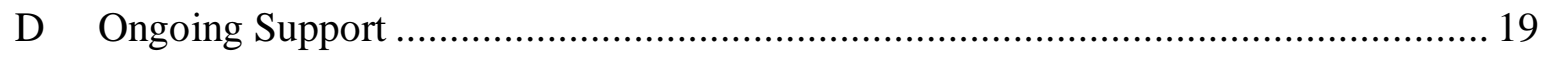

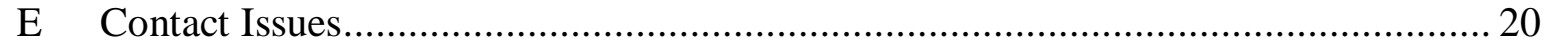

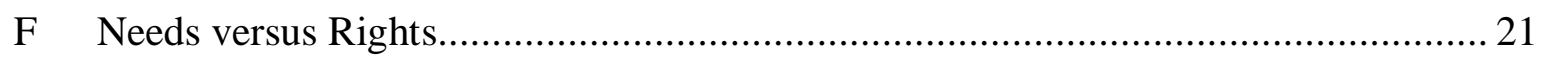

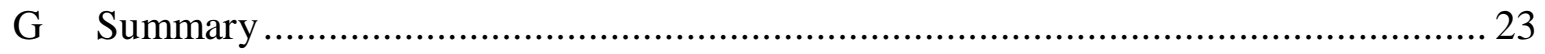

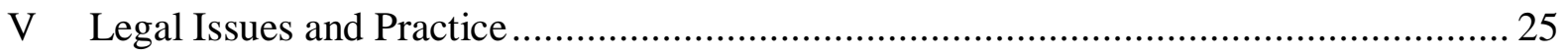

A The Care of Children Act and the Children, Young Persons, and Their Families Act25

1 General statements about the two statutes .......................................................... 26

2 Principles of the statutes ............................................................................... 29

(a) The welfare and best interests ..................................................................... 29

(b) Other principles in $\mathrm{s} 5$ of the Care of Children Act ......................................... 30

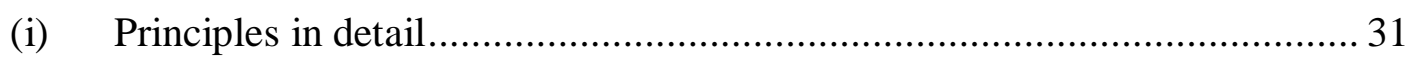

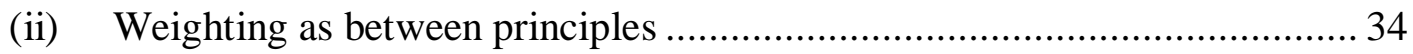

(iii) Applying to the Children, Young Persons, and Their Families Act .............. 35

(c) Principles in the Children, Young Persons, and Their Families Act ................. 36

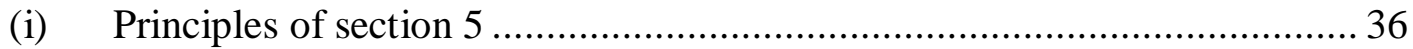

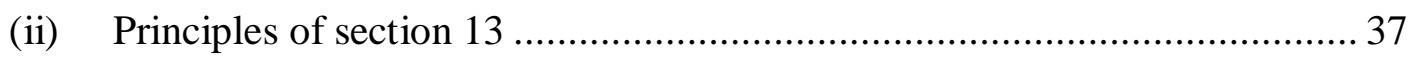

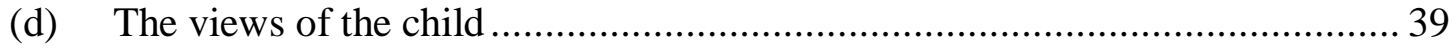

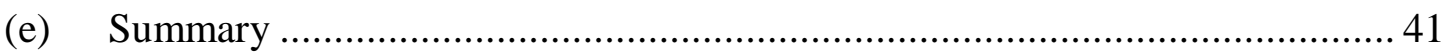

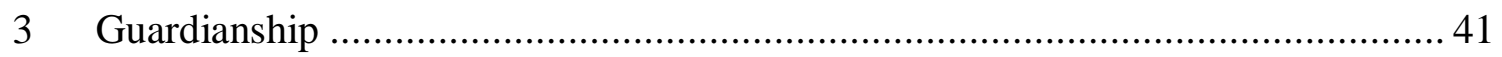

(a) Guardianship defined and the exercise of guardianship .................................42 42

(i) Meaning of guardianship ....................................................................... 42

(ii) Guardianship as a dwindling right ......................................................... 44

(iii) Further provisions regarding the exercise of guardianship rights................. 45 
(iv) Guardianship under the Children, Young Persons, and Their Families Act . 46

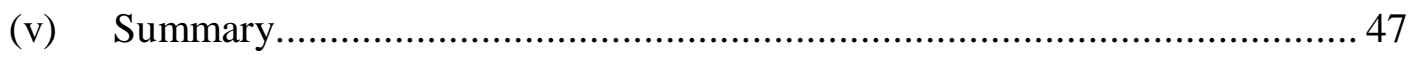

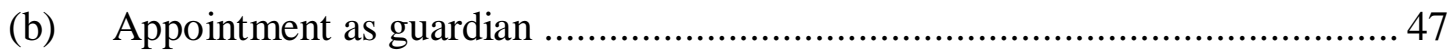

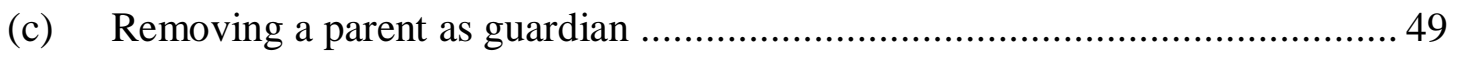

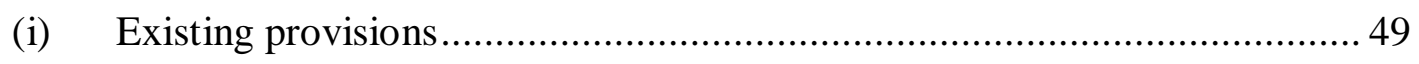

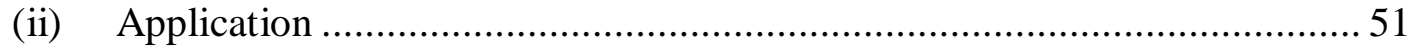

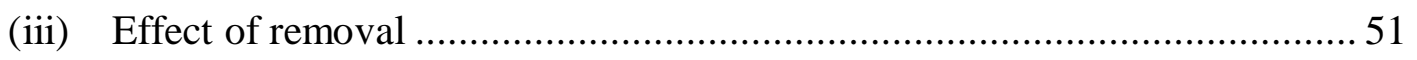

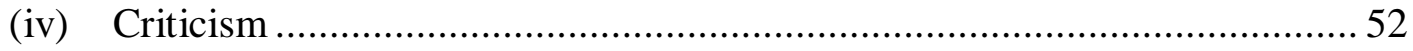

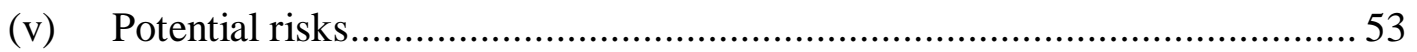

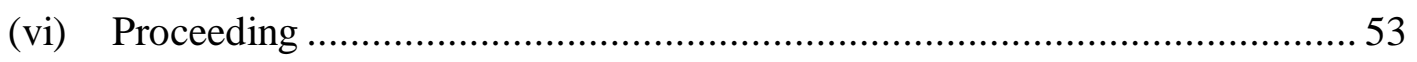

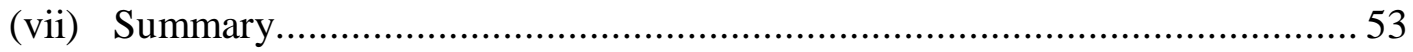

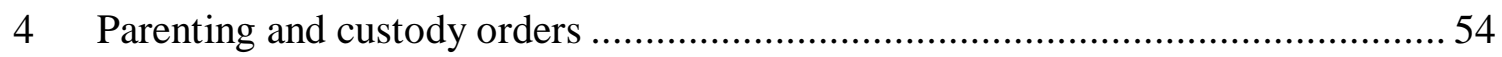

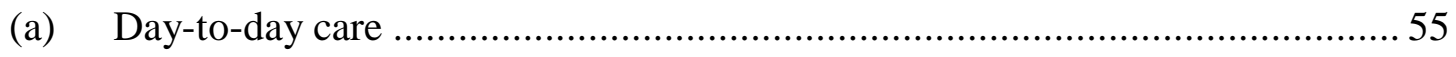

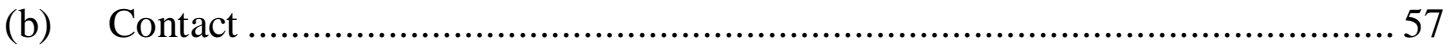

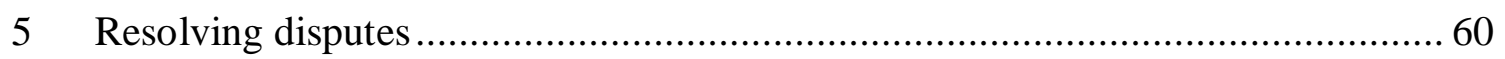

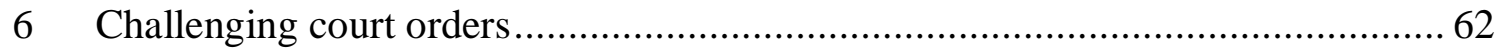

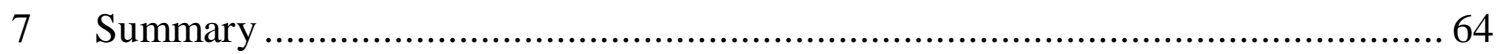

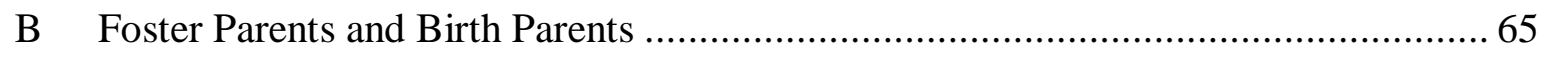

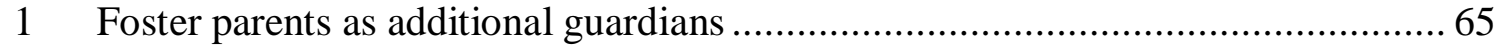

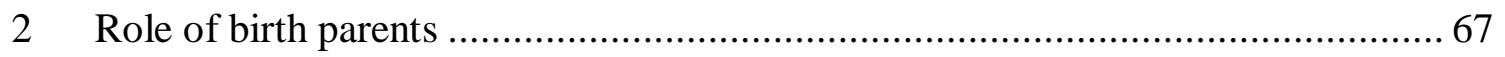

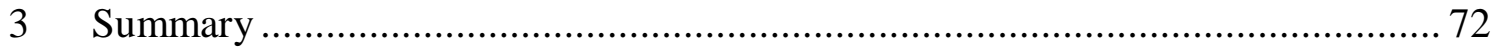

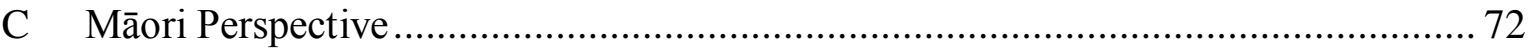

D The Practice of Child, Youth and Family ........................................................ 75

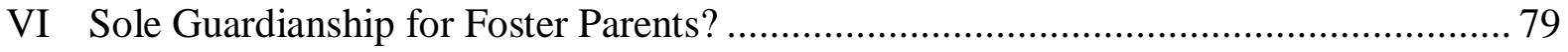

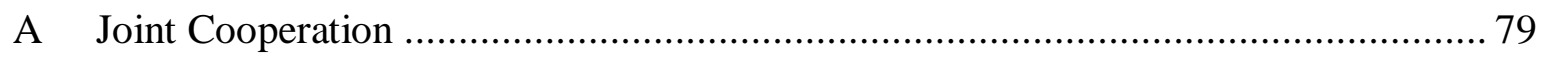

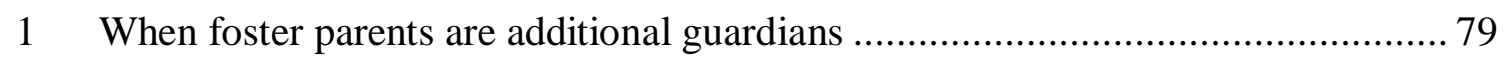

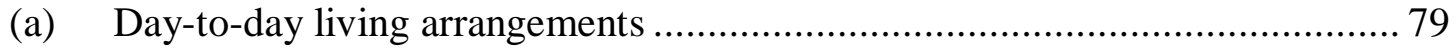

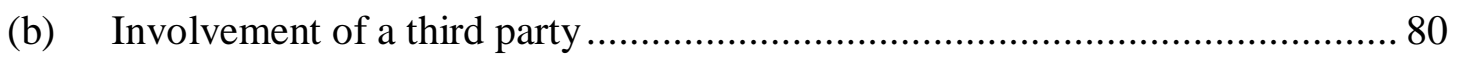

(c) Comparison with disputes between mother and father ............................... 80

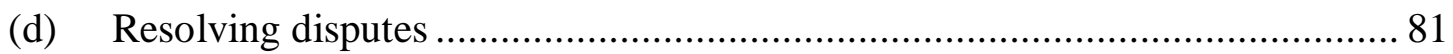

2 When foster parents have a parenting order in their favour .............................. 81 


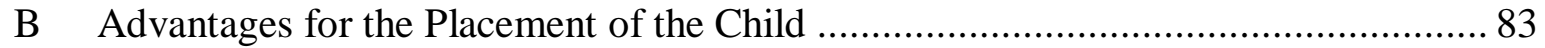

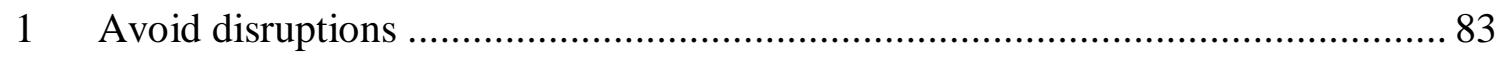

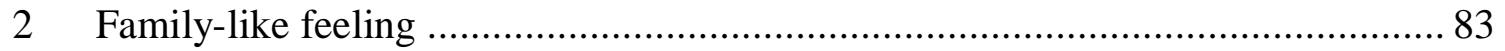

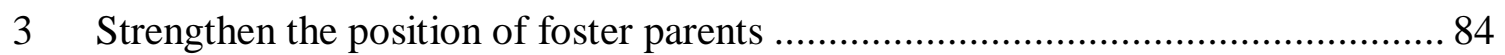

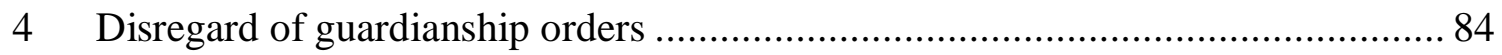

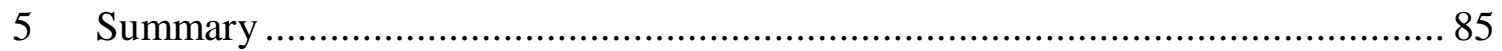

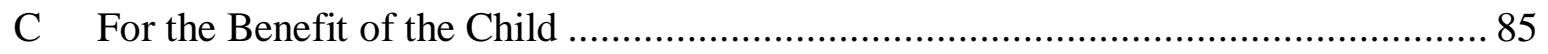

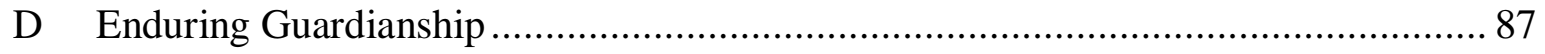

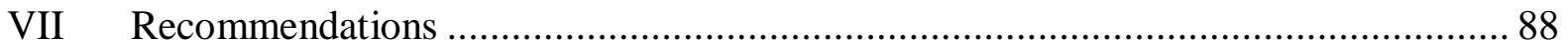

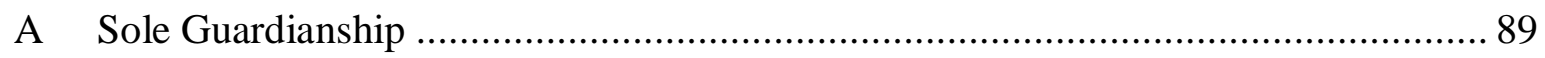

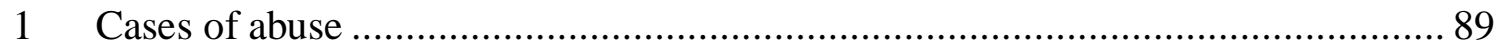

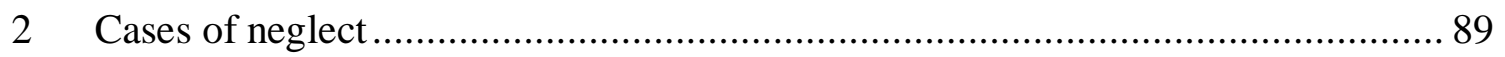

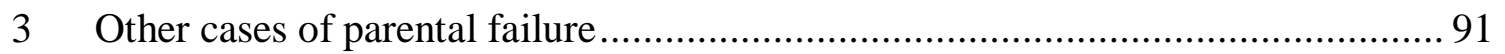

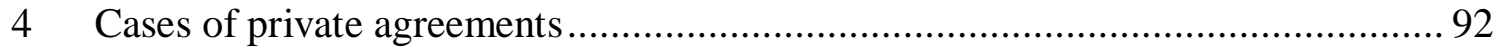

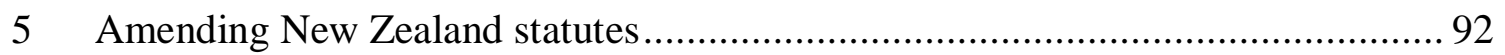

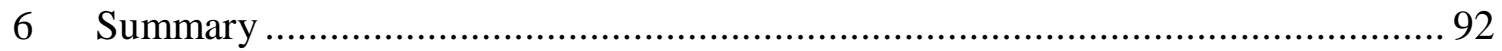

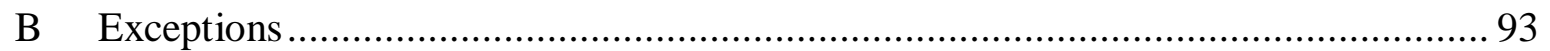

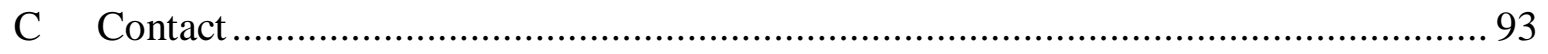

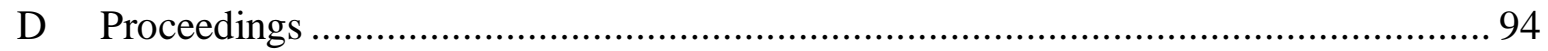

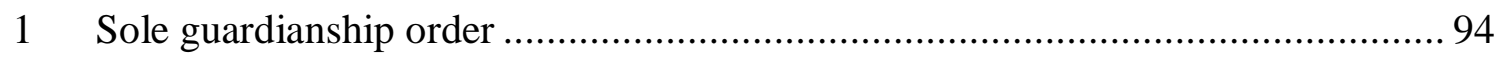

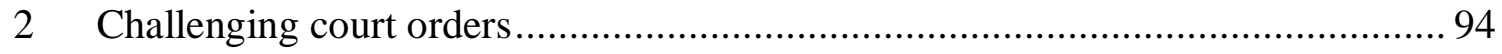

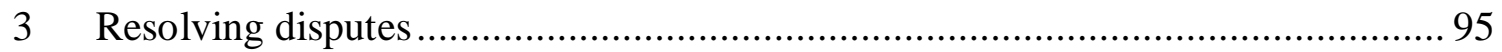

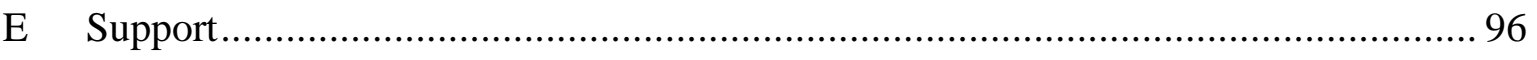

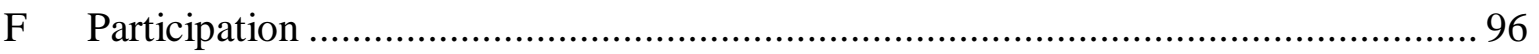

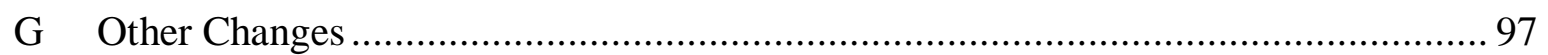

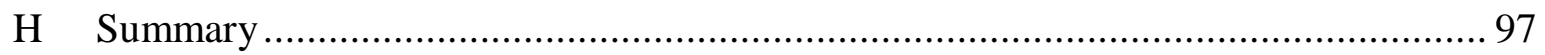

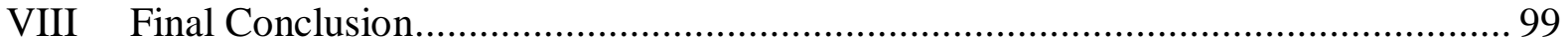

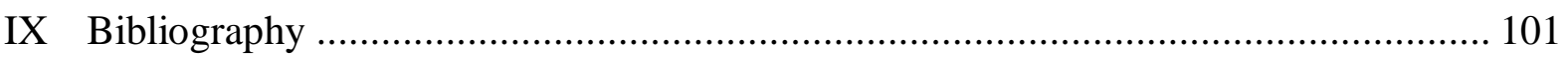

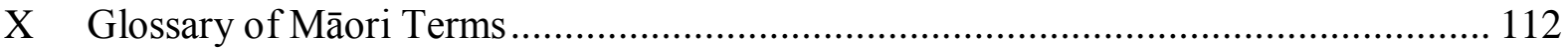




\begin{abstract}
This dissertation analyses whether permanent caregivers should be given sole guardianship responsibilities. It shows that the current legal regulations are not sufficient to secure the placement of a child with foster parents on a permanent basis. Therefore, it examines not only the Care of Children Act 2004 and the Children, Young Persons, and Their Children Act 1989, but also the Green Paper for Vulnerable Children as well as the White Paper for Vulnerable Children, launched in October 2012 by the Ministry of Social Development. The White Paper contains a suggestion to limit parental rights in order to secure the "Home for Life" policy, but fails to discuss the proposed amendments in depth and does not set out detailed provisions. In order to fill the gap in the present debate, this dissertation contains recommendations to amend the current legal provisions.
\end{abstract}

\title{
Word length
}

The text of this dissertation (excluding abstract, table of contents, footnotes, bibliography and appendix) comprises approximately 35,823 words.

\section{Subjects and Topics}

Child Guardianship

Permanent Placement

Care of Children Act 2004

Children, Young Persons, and Their Families Act 1989

Green Paper for Vulnerable Children

White Paper for Vulnerable Children 


\section{Introduction}

This dissertation focuses on vulnerable children who are in need of care and protection. Children are full members of the human family with special rights and needs. They desire to grow up in a family environment that will enable them to develop individual personalities for life in society. ${ }^{1}$ Children are "considered as people to be nurtured, not objects to have their ownership negotiated", ${ }^{2}$ but also: ${ }^{3}$

The very fact of their physical weakness, immaturity, lack of knowledge and experience renders children dependent on the adults around them. For very young children their survival depends on the quality of care and commitment provided for them by the adults who have responsibility for them. They need shelter, food, education, health care, affection and protection and their survival is dependent on the willingness and capacity of adults to meet these needs.

Where parents do not fulfil their duties, a third person has to step in. In such a case, children's rights have to be taken into account and every decision made must be for the benefit of the child. In most cases foster parents are this "third person". Where children are permanently placed with them the law should secure this placement and the chance for the child to grow up in a family-like setting. Foster parents can obtain parenting and guardianship orders to secure the placement and receive legal responsibility. Unfortunately, this does not protect the placement from disruption by the birth parents.

The Ministry of Social Development launched the White Paper for Vulnerable Children in October 2012, after the public had the chance to submit proposal in regard to the Green Paper for Vulnerable Children. ${ }^{4}$ This included plans to stabilise and secure permanent placements. The Minister of Justice, on the other hand, proposed regulations to reform the Family Court. ${ }^{5}$ One suggestion is to limit access to the Family Court in cases of vexatious applications. Unfortunately, the White Paper fails to discuss the issue of permanent placement and necessary court orders in depth nor does it set out any detailed provisions. This dissertation seeks to fill the gap in the present debate.

In having a closer look on the White Paper, I suggest to grant permanent foster carers sole guardianship, thus excluding birth parents. This involves a balance between security and

United Nations Convention on the Rights of the Child GA Res 44/25 (1989), preamble.

Susan Smith "Protection and identity: Finding the right balance to belong" (2012) 7 NZFLJ 124 at 125.

Gerison Lansdown "Children's rights" in Berry Mayall (ed) Children's childhood: Observed and Experienced (The Falmer Press, London, 1994) 33 at 34.

Paula Bennett, Ministry of Social Development "The White Paper for Vulnerable Children" (Wellington, 2012); "Green Paper for Vulnerable Children - Complete Summary of Submissions" (Ministry of Social Development, Wellington, August 2012); see also below chapter III at 6.

Minister of Justice "Family Court Review: Proposals to Reform" (2012); see also Family Court Proceedings Reform Bill 2012. 
identity of the child. If carers get more responsibilities and rights, the birth parents will lose influence. The connection between the child and the birth parents can be altered in a way that renders the return of the child to the birth family impossible. However, granting caregivers more rights also means more protection for the child, with the possibility of living with and experiencing the foster family as a "normal" family and as a full member.

After examining the recent political developments in chapter III, key principles which should guide a decisions-making process are set out in chapter IV. Chapter V is about the two important New Zealand statutes which relate to care and placement of a child. This chapter also takes a look at the role of foster parents and birth parents as well as it deals with questions relating to a Māori perspective. Furthermore, the practice of Child, Youth and Family is examined. In chapter VI the question is answered and justified whether or not foster parents should be given sole guardianship responsibilities. Finally, chapter VII contains recommendations to amend the current legislation. However, starting point of the dissertation are the children in foster care. 


\section{Children in Foster Care}

Before even considering changing laws it is important to be aware of the real life situation of those concerned. The question of whether permanent caregivers should be given sole guardianship responsibility concerns the birth parents and caregivers. However, more important are the children who are permanently placed. The caregivers should be entitled to sole guardianship responsibility only for the benefit of the child.

A permanent placement will occur only as the last resort. ${ }^{6}$ In June 2012, 3.884 children were in out of home placements in New Zealand. ${ }^{7}$ Before a child is removed: ${ }^{8}$

The necessary assistance and support should be provided to enable the child or young person to be cared for and protected within his or her own family, whānau, hapū, iwi, and family group.

On the other hand, this also means that children entering foster care have a complicated legacy. Children who are permanently placed have previously "often" undergone different placements. They concerned carry emotional burdens: ${ }^{9}$

It is clear that children enter foster care with significantly higher rates of psychiatric disorder, development delay, behavioural problems, academic and learning difficulties and health issues than the norm and even more than similarly economically disadvantaged children. In addition, the separation from family and multiple placements disruptions typically experienced by children in foster care often compound their problems.

Furthermore, "the vast majority of children placed in foster care have been placed due to abuse or neglect." 10 Bernard and Dozier distinguish physical neglect as "abandonment and failure to provide healthcare" and emotional neglect as "inattention to the needs for affection, failure to provide psychological care, and domestic violence." ${ }^{11}$ Neglect can be caused by several factors such as parental substance abuse, poverty and homelessness. ${ }^{12}$ Besides neglect and abuse, parental illness, parental imprisonment or death can be reasons for children

See the home for life policy in chapter V D at 76.

Child, Youth and Family "Children in care and foster carers" (30 June 2012) <www.cyf.govt.nz>.

Children, Young Persons, and Their Families Act 1989, s 13(d).

Robert W Plant and Lesley Siegel "Children in Foster Care: Prevention and Treatment of Mental Health Problems" in Thomas P Gullotta and Gary M Blau (eds) Family influences in childhood behavior and development (Routledge Taylor \& Francis Group, New York, 2008) 209 at 211.

$10 \quad$ At 211.

11 Kirstin Bernard and Mary Dozier "Adoption and Foster Placement” in Marshall M Haith and Janette B Benson (eds) Encyclopaedia of Infant and Early Childhood Development (Academic Press, San Diego, 2008) 25 at 27.

At 27. 
entering foster care. ${ }^{13}$ These facts should be borne in mind when thinking about a way to create living conditions for those affected children that allow them to experience a "normal" upbringing. This dissertation focuses especially on children of abusive and neglectful parents.

Another point which has to be mentioned is the question of adoption. ${ }^{14}$ Children who are not able to return to their birth families may be adopted, so the new caregivers have all the responsibilities and rights. However, even taking into consideration the advantages adoption might bring, this is not an option for all children: children who do not want to be adopted; children who are close to their new caregivers who do not want an adoption and moving the child to other caregivers would not be in their interests; in situations in which the relationship between the new caregivers and the child is not yet established and they still wish to get to know each other before making such a great step; and of course, children who still have a strong attachment to their birth family, for example, in cases where the parents cannot provide a home for the child, but still have an emotional bond. Adoption may also not be appropriate in cases of kinship placements due to incoherent results: the aunt becomes the mother and the mother becomes the aunt or the grandfather becomes the father and the father becomes the brother. Finally, Māori culture does not approve the severance of the legal relationship between child and birth parents or whānau that adoption involves. ${ }^{15}$

As mentioned, adoption might have some advantages compared with permanent placements. Research shows that children in foster care think that an adoption provides more security. Triseliotis compared long-term foster care and adoption and stated: ${ }^{16}$

Because of the lack of legal security, which meant that the placement could be terminated at any time, many children and foster carers were left in a continual state of anxiety of what might happen next.

Furthermore, he discovered that children in long-term foster care are in an ambiguous position and they do not have the feeling of "belonging": 17

They do not live with their biological parents, and often are not in touch with them, yet their carers are not their 'parents', and neither can they call them 'mum' or 'dad' by right. This ambiguity appears to lead to a sense of unusualness and difference, experienced especially in school and at play.

$13 \quad$ At 27

14 This dissertation focuses on permanent placements. Adoption will only be mentioned at some points, but not examined in detail.

15 Joan Metge and Jacinta Ruru "Kua Tutū Te Puehu, Kia Mau: Māori Aspirations and Family Law Policy" in Mark Henaghan and Bill Atkin (eds) Family Law Policy in New Zealand (3rd ed, LexisNexis, Wellington, 2007) 47 at 61.

16 John Triseliotis "Long-term foster care or adoption? The evidence examined" (2002) 7 Child and Family Social Work 23 at 28. 
Even in long-term foster care children feel less secure and their sense of belonging is weaker. Especially in cases in which adoption is not an option the law should provide regulations which might help to counteract the disadvantages identified above. Due to the fact that adoption is rare in New Zealand this dissertation focuses on another permanent solution for children in foster care. 


\section{Recent Developments}

The Ministry of Social Development launched on the 27 July 2011 the Green Paper "Every child thrives, belongs, achieves - Ka whai orange, ka whai wāhi, ka whai traumata ia tamaiti". ${ }^{18}$ This Green Paper for Vulnerable Children sketched ideas to improve the life of vulnerable children and wanted to discuss them with the public. ${ }^{19}$ Inter alia the paper examined that in 2009/2010 21,000 cases of child abuse and neglect were confirmed by Child, Youth and Family. ${ }^{20}$ Furthermore, 1,286 hospital admissions of children in 2008/2009 were the result of assault, neglect or maltreatment. ${ }^{21}$ The vision of the government is that every child should thrive, belong and achieve. Thrive is seen as being healthy, protected from harm and having basic needs met; belong means be loved and supported, confident with own identity and have good relationships with family and friends; children should achieve strong foundations for lifelong learning, achieve in their own culture and have the support needed to contribute positively to their future. ${ }^{22}$

The paper asked several questions like: "When should government agencies step in and intervene with families and whānau?"23 or "What ... actions or principles would you like to see included in the legislation?" 24 The public was asked to comment by 28 February $2012 .{ }^{25}$ Almost 10,000 submissions were received from children, the general public, organisations and frontline workers. ${ }^{26}$ Regarding responsibility for children, for example, "submissions drew attention to the needs of particular groups of carers; for example grandparents, foster parents, teen parents and carers of children with disabilities. ${ }^{27}$ Furthermore, it was said that the balance between support and protection is not right: "the needs of children should come before the needs of parents and caregivers, particularly when children were at risk." 28 Moreover, it was "argued that government should step in 'as early as possible', particularly

18 Paula Bennett, Ministry of Social Development "Every child thrives, belongs, achieves - Ka whai orange, ka whai wāhi, ka whai traumata ia tamaiti” (Wellington, 27 July 2011).

At iv.

At 2.

At 2.

At 2 .

At 10 .

At 16 .

At 32 .

They are summarised in the one-page "Summary of Submissions on the Green Paper for Vulnerable Children", in the "Executive Summary of Submission on the Green Paper for Vulnerable Children" (Ministry of Social Development, Wellington, August 2012) and in the "Green Paper for Vulnerable Children - Complete Summary of Submissions" (Ministry of Social Development, Wellington, August 2012).

27 "Executive Summary of Submission on the Green Paper for Vulnerable Children" (Ministry of Social Development, Wellington, August 2012) at 8; "Green Paper for Vulnerable Children - Complete Summary of Submissions" (Ministry of Social Development, Wellington, August 2012) at 10.

"Executive Summary of Submission on the Green Paper for Vulnerable Children" (Ministry of Social Development, Wellington, August 2012) at 9; "Green Paper for Vulnerable Children - Complete Summary of Submissions” (Ministry of Social Development, Wellington, August 2012) at 11. 
where risk was identified." ${ }^{29}$ Besides, submissions postulate "greater consequences for those who neglect and/or abuse children" ${ }^{30}$ and "harsher consequences for maltreatment." addition, non-parental carers of vulnerable children should get more support, for example, grandparents and foster parents. ${ }^{32}$

In October 2012 the White Paper for Vulnerable Children was published by the Ministry of Social Development as the government response to the submissions made on the Green Paper. ${ }^{33}$ It contains the actions to be taken to protect vulnerable children. One of these steps is the introduction of new guardianship orders. The guardianship rights of parents should be curtailed or limited by the Family Court, where they are a serious risk to their child. ${ }^{34}$ Children should get a "safe and secure fresh" start in a "permanent, secure and loving home" where they have been seriously abused. ${ }^{35}$ These new guardianship orders shall give security to caregivers and address their and the child's specific needs. ${ }^{36}$ Furthermore, they should finalise the Home for Life ${ }^{37}$ care arrangement. ${ }^{38}$ More precisely, the new guardianship order shall increase security and stability by: ${ }^{39}$

... reducing or limiting the guardianship rights of parents by enabling the Family Court to direct which guardianship powers reside exclusively with the caregivers and which are shared with the child's natural parents or other guardians;

requiring a significant change in circumstances before a care order could be challenged

"Executive Summary of Submission on the Green Paper for Vulnerable Children" (Ministry of Social Development, Wellington, August 2012) at 9; "Green Paper for Vulnerable Children - Complete Summary of Submissions" (Ministry of Social Development, Wellington, August 2012) at 11.

"Executive Summary of Submission on the Green Paper for Vulnerable Children" (Ministry of Social Development, Wellington, August 2012) at 10; "Green Paper for Vulnerable Children - Complete Summary of Submissions" (Ministry of Social Development, Wellington, August 2012) at 12.

"Executive Summary of Submission on the Green Paper for Vulnerable Children" (Ministry of Social Development, Wellington, August 2012) at 11; "Green Paper for Vulnerable Children - Complete Summary of Submissions" (Ministry of Social Development, Wellington, August 2012) at 13.

"Executive Summary of Submission on the Green Paper for Vulnerable Children" (Ministry of Social Development, Wellington, August 2012) at 13; "Green Paper for Vulnerable Children - Complete Summary of Submissions" (Ministry of Social Development, Wellington, August 2012) at 16.

Paula Bennett, Ministry of Social Development "The White Paper for Vulnerable Children" (Wellington, 2012).

Paula Bennett, Ministry of Social Development "The White Paper for Vulnerable Children" (Wellington, 2012) volume I at 20.

At 20.

Paula Bennett, Ministry of Social Development "The White Paper for Vulnerable Children" (Wellington, 2012) volume II at 124.

The Home for Life policy is the permanency policy of Child, Youth and Family. Its goal is to give every child a permanent home. See also below chapter V D at 75.

Paula Bennett, Ministry of Social Development "The White Paper for Vulnerable Children" (Wellington, 2012) volume II at 124; regarding the Home for Life policy see also below chapter V D at 75 . At 124-125. 
assuring Home for Life parents that they will be supported should the child's parents attempt to disrupt the placement.

The remaining questions are: What is meant by limiting or reducing guardianship rights? What is the difference between limiting and reducing? For how long? Can parents recover them? Who should get these if parents do not have them? At which point in the process? What kind of rights?

The suggestion is a positive and good step towards a securer placement and better upbringing of the child. Nevertheless, the questions listed above have to be answered. Unfortunately, the White Paper does not contain as much detail as it does in comparison to the new Child Abuse Prevention Order. Furthermore, the only support mentioned relates to preventing possible disruption caused by parents without examining in detail what kind of support they will receive. Beyond this, the child and the permanent caregivers may need more support, for example, psychological and financial support. ${ }^{40}$

In the following sections this dissertation seeks to show that the suggestions made in the White Paper are not sufficient to improve the situation for children permanently placed and their new caregivers. To fill the gap, the recommendations provide more details to amend the current legislation. 


\section{Key Principles}

Every decision made in this realm of law has a deep personal impact on the person concerned. The development of the child is influenced by many different adults. The law should provide them with several rules to guide and to prevent disputes. All this should be done for the benefit of the child. In most of the cases the child is the most vulnerable person, the person who is most affected and the person who contributes the least to the situation.

An examination of the existing rules as well as a suggestion of alterations to the provisions in favour of the benefit of the child cannot be done without setting a framework of key guiding principles. To my mind, there are five key principles in favour of the child which should be considered and which the following sections examine. Some of these can be found in the different statutes relevant to the relationship between parents and child or the placement of and care for a child. ${ }^{41}$

\section{A The Welfare and Best Interests of the Child}

The welfare principle is a common axiom that can be found in various jurisdictions. The New Zealand law relating to children declares it to be "the first and paramount consideration". ${ }^{42}$

Welfare is a difficult concept to define. Rather, a description is used to clarify the principle: ${ }^{43}$

Once basic needs have been met, the ways in which individuals define, determine and construct their own welfare and well-being are likely to vary considerably, depending upon a wide range of personal and cultural factors, and the social, economic and political context in which they live. Thus welfare ... is not an absolute but a relative concept.

The distinction contained in the New Zealand legislation between welfare and (best) interests complicates the definition. The Oxford English Dictionary defines welfare as "state or condition of doing or being well; good fortune, happiness, or well-being (of a person ...); thriving or successful progress in life, property". "In contrast, "interest" is defined as "good, benefit, profit, advantage". ${ }^{45}$ Both terms do not mean the same. Judge O'Dwyer distinguished them in a case decided under the Care of Children Act 2004 (COCA) as follows: ${ }^{46}$

\footnotetext{
41 This section gives an overview over important principles. Below, a discussion of them in relation to the Care of Children Act 2004 and the Children, Young Persons, and Their Families Act 1989 can be found as well as recommendations.

$42 \quad$ See Care of Children Act, s 4; Children, Young Persons, and Their Families Act, s 6. Allison James and Adrian James Key Concepts in Childhood Studies (Sage Publications Ltd, London, 2008) at 143.

44 Oxford English Dictionary (2nd ed, 1989, online ed) Welfare at [1a]

45 Oxford English Dictionary (2nd ed, 1989, online ed) Interest at [2b].

46 C v W [Custody] [2005] NZFLR 953 at [24].
} 
The addition of the term "best interests" in s 4 of COCA underlines that a decision must focus not only on the immediate day-to-day welfare of a child such as care and nurture, but also the long-term interests of ideally maintaining relationships with both parents. It had become common under the Guardianship Act for "best interests" to be considered alongside "welfare", although that Act only used the term "welfare". The inclusion of "best interests" in the new legislation highlights the importance of the Court looking at the longer term developmental, educational, cultural, and familial needs of a child.

The same point is made by Bisson $\mathbf{J}$ in Director-General of Social Welfare $v$ L. ${ }^{47}$ Judge McAloon interpreted: ${ }^{48}$

... welfare as meaning matters relating to day to day care, such as the provision of a suitable environment, adequate food, clothing, shelter, hygiene, schooling, stability, and general daily oversight and management. Best interests relates to matters which are more long term such as preparation for the future, teaching life skills, role modelling and kindred aspects of parenting.

Nevertheless, welfare and best interests cannot be defined in a general sense. Of course, general goals can and should be set. However, every child is different and the welfare and best interests of the particular child have to be considered in light of his or her particular circumstances. $^{49}$

On the other hand, there are a few general statements that can be made. Children need a secure base in which they grow up and develop their individual personality - in favour of their welfare and best interests. Schofield and Beek ${ }^{50}$ identified different issues which are important in establishing this sense of security. They name five dimensions, each associated with a developmental benefit. ${ }^{51}$ First, the caregiver should be physically and emotionally available, so the child can learn to trust. ${ }^{52}$ Furthermore, their studies showed that even at a later stage in their lives young people needed their former foster parents and the feeling that they are available was essential to them. ${ }^{53}$

For the welfare and best interests of a child mental health is important and part of this is the competence to manage feelings and behaviour. One of the dimensions for a secure base identified by Schofield and Beek is sensitivity, so the foster child can learn to name emerging

\footnotetext{
$47 \quad$ Director-General of Social Welfare v L [1989] 2 NZLR 314 at 325.

$48 \quad M v O$ FC Te Awamutu FAM-2005-072-185, 26 June 2007, at [57].

49 See Care of Children Act 2004, s 4(2).

50 Gillian Schofield and Mary Beek "Growing up in foster care: providing a secure base through adolescence" (2009) 14 Child and Family Social Work 255.

At 259 .

At 260 .

At 261 .
} 
feelings and manage them and can also comprehend the behaviour, feelings or thoughts of the caregiver, which means the child can develop emotional intelligence. ${ }^{54}$

The third issue caregivers should attempt to fulfil is acceptance ${ }^{.5}$

Accepting the young people for who they were and building their self esteem and acceptance of themselves were often mentioned by foster carers in this study as central to their parenting.

Fourthly, caregivers should form an alliance and work together with the child to solve problems. ${ }^{56}$ Children in foster care often experience powerlessness or an excess of dominance, becoming aggressive for example, depending on the lives they had in their birth families and these experiences continue while in care, because often decisions are made out of their sight or because of their destructive behaviour children initiate further movements. "Fo "Fosterfamily life needs to modify such experiences by teaching children and young people the benefits of the appropriate exercise of choice, power and co-operation." 58

Fifthly, ensuring the child feels part of the family mean not only that foster parents offer continuing involvement and support, but that the child can also experience the feeling of belonging. ${ }^{59}$

These different issues can not only secure the successful placement of a child, but furthermore contribute to making the placement harmonious and family-like. This supports the welfare and best interests of the child.

Due to the difficulty in defining welfare it is important to look at other aspects in order to clarify the meaning of this undefined legal term. Several of these will be examined as key principles in the following sections. However, at this point it should be kept in mind that welfare and best interests can be "a powerful tool in the hands of adults". ${ }^{60}$ The term is so vague that it can be used to justify different decisions and even overrule the views and wishes of the child. Lansdown said: "The welfare principle serves to perpetuate the structural vulnerability of childhood rather than seek to provide children with greater opportunities for

\footnotetext{
$54 \quad$ Gillian Schofield and Mary Beek "Growing up in foster care: providing a secure base through adolescence" (2009) 14 Child and Family Social Work 255 at 261.

$55 \quad$ At 262.

At 263 .

At 263 .

At 263 .

At 264 .

Gerison Lansdown “Children's rights" in Berry Mayall (ed) Children's childhood: Observed and Experienced (The Falmer Press, London, 1994) 33 at 41.
} 
taking control of their own lives." 61 The weakness of welfare and best interests as a principle is that adults determine what is best for children. The principle is interpreted from the perspective of an adult. This confirms the supposition that "children are not respected as human beings who have an important contribution to make to society, and that their voices are rarely listened to." 62 The United Nations Convention on the Rights of the Child proclaimed another image of the child: the child as a full member of the human family with rights, and not the immature property of their parents. The previously mentioned assumption is in contrast to that image of the child. Therefore, it is important to define welfare and best interests from a child's point of view and to support this determination by a consideration of other essential rights and needs.

However, even though the welfare has to be considered differently for every specific child, basic needs have to be met, starting with food, clothing and shelter as well as education and ending with a secure and harmonious family-like setting. Every child has a right to experience this and to have these basic needs met.

\section{B Permanency}

The second key principle to be examined and simultaneously supports the child's welfare is permanency. This could be understood as creating: ${ }^{63}$

... a permanent living arrangement that provides continuity of relationships with nurturing caregivers where there is a sense of emotional, cultural and personal belonging, and the opportunity for life long attachments ... Permanency is a way of thinking, planning and acting in statutory social work practice that promotes belonging, attachment, continuity and stability in a child or young person's life.

Permanency in the living situation is a relevant factor to the child's welfare. As mentioned above, the development of a sense of belonging secures the placement of a child and is, at least, one of the most basic means of promoting the child's welfare. A sense of belonging can only be cultivated if the placement is a permanent one. The arrangements made for the child's care, development and upbringing should be long-term. Keeping in mind the difficult living

61 Gerison Lansdown “Children's rights" in Berry Mayall (ed) Children's childhood: Observed and Experienced (The Falmer Press, London, 1994) 33 at 42.

62 Anne B Smith "Children's rights: An overview" in Anne B Smith and others (eds) Advocating for children: International Perspectives on Children's Rights (University of Otago Press, Dunedin, 2000) 13 at 16.

63 Department of Child, Youth and Family Services Children in care: Permanency policy (unpublished, Wellington, 2006) as cited in Allan Cooke "Permanency for children: why permanently placed children need ongoing support, and how to deliver that support" (2008) 6 NZFLJ 37 at 38. 
situations the children come from, it is important for them to experience a real family life. Thus, the existing disadvantages can be compensated for: ${ }^{64}$

The encouraging news is that the removal from a neglectful environment and the provision of appropriate human contact and stimulation through placement in foster care can reverse these delays [mentioned above $\left.{ }^{65}\right]$... [In] many cases, the impact of abuse and neglect can be reduced with proper care.

Due to the therapeutic nature of the care that is given, children can be prompted to overcome their difficult early childhood years. However, this requires an ongoing relationship with the responsible adult, because a bond of trust can only be created in this way. Continuous changes in the living arrangements of the child cause recurrent disruptions of existing relationships so that the child cannot develop a feeling of belonging or confidence. If a child has been permanently removed from the birth family one guiding principle should be the intention that the child becomes a permanent member of the new family.

Another important point in connection with permanency which might be hard to address is the attitude of the new caregivers. Triseliotis mentioned that the feeling of uncertainty derives, of course, from the possibility not only of an adoption by others, but also of challenging of court orders. Furthermore, the precariousness may be caused by the foster parents themselves: ${ }^{66}$

\begin{abstract}
Examples of such unpredictabilities include foster carers who in all honesty say they will look after a 2- or 3-year-old for the remainder of their childhood, only to give up after 6 , 8 or even 10 years. At such a late stage it is almost impossible to find an adoptive home for the child, especially for a boy. The scenario that usually follows is a succession of temporary fostering placements with the child eventually growing up without a family to call their own and no social base in life. Yet uprooting can prove very traumatic to the child.
\end{abstract}

Furthermore, foster parents may not be able to cope with the behaviour of the child or their life circumstances may change and so they are no longer able to care for the child.

Moreover, the reality shows that permanency is often illusory. It will be shown that the parental responsibility is often not solely held by the new caregivers. In fact, the chief executive or even the birth parents retain rights and possibilities. So, the actual regulations

$64 \quad$ Robert W Plant and Lesley Siegel "Children in Foster Care: Prevention and Treatment of Mental Health Problems" in Thomas P Gullotta and Gary M Blau (eds) Family influences in childhood behavior and development (Routledge Taylor \& Francis Group, New York, 2008) 209 at 212.

$65 \quad$ See above chapter II at 3.

66 John Triseliotis "Long-term foster care or adoption? The evidence examined" (2002) 7 Child and Family Social Work 23 at 31. 
themselves give rise to problems which might affect the development of a sense of belonging and the permanency of a placement. Furthermore, guardianship orders or parenting orders and consequently the relationship between child and new caregivers can be challenged by different parties such as the birth parents. ${ }^{67}$ This could destabilise the placement as well.

However, Judge Maude noted "that permanency is but a word." ${ }^{68}$ Permanency does not mean that in the future there cannot be a change of the decision: ${ }^{69}$

... for some, as yet unforeseen, reason. That said, once a plan of permanency is accepted, the Court will be [loath] to interfere with that other than for reasons of serious risk.

Even if, as Judge Ryan stated, “[statistically a] permanent placement with foster parents often fails", ${ }^{70}$ children should be moved as little as possible and should have the opportunity to experience a real family life and a sense of belonging, to establish strong and functional relationships with others. They should also be given the opportunity to develop a significant psychological attachment to the person in whose care they are placed - promoting their welfare and best interests as the paramount consideration.

\section{Participation}

Another key principle to examine is the participation of the child in all processes or decisions. As mentioned above, the term welfare and best interests is vague and can justify different decisions at the same time and, of course, can be misused as well. Furthermore, it can be used to override the feelings, wishes and views of children: ${ }^{71}$

The application of a welfare principle which fails to address the right of children to participate in decisions which affect them is to undermine their capacity for selfdetermination. The welfare principle serves to perpetuate the structural vulnerability of childhood rather than seek to provide children with greater opportunities for taking control of their own lives.

Therefore, it is important to give children the opportunity or perhaps even the right to participate.

$67 \quad$ See below chapter V A 6 at 62

68 Ministry of Social Development v C-P F FC Kaikohe FAM-2008-027-000351, 26, 27 May 2011 at [41].

69 At $[41]$

$70 \quad$ Ministry of Social Development v C FC North Shore FAM-2005-004-001166, 19 February 2010 at [17].

71 Gerison Lansdown “Children's rights" in Berry Mayall (ed) Children's childhood: Observed and Experienced (The Falmer Press, London, 1994) 33 at 42. 
In the last century children were assumed to be the property of their parents and the recognition that children have rights was lacking. "Children are regarded as immature, irrational, incompetent, asocial [and] acultural' with adults being 'mature, rational, competent, social and autonomous". ${ }^{72}$ The understanding of childhood has changed in recent years. Assuming that children are immature, irrational, incompetent, asocial and acultural contradicts our current understanding and deprives them of their status as a full member of the human family.

One of the fundamental rights is participation, especially in matters that personally affect an individual. Often children are denied this right. It is argued that children cannot handle the responsibility that comes with the opportunity to participate. Children are not able to foresee the consequences: ${ }^{73}$

... children are seldom in a position to determine what constitutes their own welfare. They are rarely consulted by adults in order to determine their views and understandings of what might be for their welfare or in their best interests. This is, in part, a reflection of the dominant view of adults that children lack the competence to understand and decide about such issues, that they lack the experience to know how their needs can best be met, and that because they are developmentally incomplete, they are therefore vulnerable. ... Thus any rights that children have in relation to their own welfare become the responsibility of adults to meet.

The first criticism of this position is that this cannot be said in such a generic way. The ability to foresee and understand possible consequences and to handle the obligations connected with the opportunity to decide differs from child to child and increases, of course, during the process of growing-up. Second, as Atwool states, "the same can be said of many adults and yet they are not denied access to their rights on this basis." ${ }^{74}$ Continuing, she correctly points out that the denial of the right to participate, because children are not able to handle the onus, is a circular argument. "This argument also becomes a self-fulfilling prophecy because denial of rights ensures that children are never given the opportunity to take responsibility."75

72 Alan Prout and Allison James "A New Paradigm for the Sociology of Childhood? Provenance, Promise and Problems" in Allison James and Alan Prout (eds) Constructing and Reconstructing Childhood: Contemporary Issues in the Sociological Study of Childhood (2nd, Falmer Press, London, 1997) 7 at 13, citing R MacKay "Conceptions of children and models of socialisation" in H P Dreitzel (ed) Childhood and Socialization (Collier-Macmillam, London, 1973) 27-43 at 28.

73 Allison James and Adrian James Key Concepts in Childhood Studies (Sage Publications Ltd, London, 2008) at $143-144$. Nicola Atwool "Participation in Decision-making: The Experience of New Zealand Children in Care" (2006) 3 Child Care in Practice 259 at 264.

75 At 264; see also Allison James and Adrian James Key Concepts in Childhood Studies (Sage Publications Ltd, London, 2008) at 35: “... the failure of adults to give children responsibility can limit their ability to learn how o become competent and to develop their competences ...". 
Properly, the argument should be reversed: "Adults have a responsibility for ensuring that children have the opportunity to exercise their rights."

A right to participate can be found inter alia in art 12 of the United Nations Convention on the Rights of the Child, ratified in New Zealand on the 6 April $1993 .{ }^{77}$ In scrutinising the rights of children Lansdown examines art 12. To his mind a "serious application of the principle [in art 12] would require" five points, which to my mind should be self-evident. ${ }^{78}$ First, it has to be ensured that children get adequate information appropriate to their age which enables them to form opinions. ${ }^{79}$ The second point is to put children in a position to express their views and formed opinions and ascertain options with them. ${ }^{80}$ Thirdly, these opinions should be listened to and should be considered with respect and seriousness; furthermore, children should be told how their views will be considered. ${ }^{81}$ This is an important point because even if children are represented in a decision-making process, it does not necessarily mean that their views will be taken into account. ${ }^{82}$ Fourthly, he mentions that adults should let children know the outcome of any decisions, especially, if the decisions are contrary to the children's opinions and that the reasons must be wholly explained. ${ }^{83}$ This shows children how they are part of the decision-making process, even if the decision is not what they want it to be. However, participation does not mean that everything depends solely on the will of the child. Lastly adults should: ${ }^{84}$

... provide children using public services with effective, accessible and genuine avenues of complaint, backed up by access to independent advocacy for situations where children [feel] they have been mistreated or ignored or abused in any way.

In July 1999 a conference with the theme 'Children's Rights: National and International' was held at the University of Otago. During this conference, a forum consisting of seven children convened and deliberated about arts 12 and 13. Although, this was not a representative survey,

76 Nicola Atwool "Participation in Decision-making: The Experience of New Zealand Children in Care" (2006) 3 Child Care in Practice 259 at 265.

United Nations Convention on the Rights of the Child GA Res 44/25 (1989). The proposals of the White Paper of Vulnerable Children are consistent with the Convention and address some concerns made by the Committee for the United Nations Convention on the Rights of a Child. Inter alia, the White Paper develops a strategy to address child abuse and neglect, increases training for professionals and local services to assist parents to raise their child, see White Paper at 9. In developing a competent workforce a child-centred approach is taken, see White Paper at 147. It fails to improve participation rights.

Gerison Lansdown "Children's rights" in Berry Mayall (ed) Children's childhood: Observed and Experienced (The Falmer Press, London, 1994) 33 at 38-39.

At 38 .

At 39 .

At 39 .

See also Allison James and Adrian James Key Concepts in Childhood Studies (Sage Publications Ltd, London, 2008) at 29.

Gerison Lansdown "Children's rights" in Berry Mayall (ed) Children's childhood: Observed and Experienced (The Falmer Press, London, 1994) 33 at 39.

At 39. 
especially given the small number of participants, several aspects of the report from the Children's Forum can be inferred which may be of great importance for the question of participation: ${ }^{85}$

The most important information we came up with in our discussion is: we are people as well; we are all different, with different maturity levels; we are children, but we do have rights; we can make responsible decisions if we are given a chance; it is okay for us to make the wrong decision sometimes, even if we know all the information; please listen to us instead of ignoring us, and take notice of what we have to say; expect an opinion from us, and ask for it; ... you may not want to hear what we say, but we have a right to say it; lastly, we need adults to guide us towards making good decisions, but we also need you to let us practise making wrong decisions as well.

Children should get the opportunity to have a say in the matters which affect them. They should get or be able to enforce a right to participate. No one would deny that adults have this right. If a child is able to understand, why should he or she be excluded? The consideration of the wishes and views of the child supports their perception as a personality. The participation may increase the chance of forming a stable and secure attachment. At the very least the probability of a rebellion against the solution is less. Presenting children a fait accompli may increase the chances of a rejection of the placement: "Where old enough, the children must be consulted and listened to, and their views seriously considered and respected. This is also the best predictor of placement stability." 86 Children should be able to express their own views about who they live with and about the duration of the stay, as well as questions about the contact to their birth parents. ${ }^{87}$

As mentioned above, one weakness of the idea of welfare as a key principle lies in the inherent vagueness of this indefinite legal term. Even participation rights like the one provided in art 12 could be pruned for the benefit of the protection of the child determining welfare and best interests of a child in this context: ${ }^{88}$

It allows children's best interests to be determined in terms of their welfare and ... enables adults to override any wishes and feelings children themselves may have expressed about wanting to participate in decision-making processes.

85 Report from the Children's Forum published in Anne B Smith "Children's rights: An overview" in Anne B Smith and others (eds) Advocating for children: International Perspectives on Children's Rights (University of Otago Press, Dunedin, 2000) 13 at 17. Family Social Work 22 at 30.

87 Stephen Coyle "Permanency policy: children in care" (2008) 6 NZFLJ 45 at 48.

88 Allison James and Adrian James Key Concepts in Childhood Studies (Sage Publications Ltd, London, 2008) at 13 . 
Furthermore, James and James state that "the trust of the Convention is that defining and providing for the welfare of children are the responsibilities of adults. " ${ }^{89}$ This could lead to a vicious circle, to the detriment of the child and his or her rights. Therefore, it is important to respect children's views, to interpret them from a child's point of view and to take them into account seriously. Denying or pretending a child's right to participate does not exist cannot be justified because of their alleged lack of competence: $:^{90}$

Conversely, if children are given responsibility and, if necessary, guidance, they frequently demonstrate levels of competence much higher than many adults might anticipate: children learn by experience and competence grows through experience, rather than simply with age.

In accordance with Lansdown there are two possible approaches in determining the competence of a child: $:^{91}$

One possibility is that the onus should rest with the child to demonstrate competence. ... The second and more radical approach is to introduce a presumption of competence in the exercise of rights.

Assuming a child's incompetence on the basis of age is questioned by Lansdown, ${ }^{92}$ who suggests that a more appropriate solution than this radical variant above might be a "mixed model" - a fourth model proposed by him. ${ }^{93}$ Based on this, there should not be a general presumption of competence. Instead, especially in personal matters, the second approach is preferable to the first. This means that in questions of adoption, placement in care, and other similar matters: ${ }^{94}$

... the law could operate with a presumption of competence, in which the onus would be on concerned adults to demonstrate that a child was incompetent if the child's right to take responsibility for a decision was to be overruled.

Such an approach does not ignore the fact that children are not able to take care of themselves and to make decisions for themselves right from the beginning, but it delays the initial point or the focus into the area of the child. This gives more weight to the rights of the child.

Allison James and Adrian James Key Concepts in Childhood Studies (Sage Publications Ltd, London, 2008) at 144.

At 35 .

Gerison Lansdown The Evolving Capacities of the Child (Save the Children, UNICEF, Florence, 2005) at 50 .

See also Allison James and Adrian James Key Concepts in Childhood Studies (Sage Publications Ltd, London, 2008) at 36.

See Gerison Lansdown The Evolving Capacities of the Child (Save the Children, UNICEF, Florence, $2005)$ at 52.

A 52 . 
Putting the prejudice of incompetence aside and treating children as full members of the human family there is no question of whether they should be consulted or involved. "It seems that we have little to lose by increasing children's participation. ... But more importantly, taking account of children's views may lead to better decisions. ${ }^{" 95}$ Nicola Atwool states: ${ }^{96}$

Even if the outcomes of decision-making involving children are not significantly better at least they have had a chance to have a say, and this may make it easier to live with the consequences. There is nothing more damaging than the pervasive sense of powerless that results from having no voice.

\section{Ongoing Support}

Children living in foster care have experienced life situations that may have seriously affected their wellbeing. In most cases before they were permanently placed they lived in several households with different foster parents. Furthermore, most of the time they were removed from their birth family because they were in need of care and protection ${ }^{97}$. Being in "need of care and protection" requires a serious impairment of the wellbeing caused by physical, psychological, emotional or sexual harm, ill-treatment, abuse or serious social deprivation. ${ }^{98}$ To avoid (psychological) problems which may occur in the future due to the treatment of the child, ongoing support is important.

As stated above, children can leave their traumatised legacy behind growing up in proper care. ${ }^{99}$ Therefore, it is important to find a new home for life as Child, Youth and Family in New Zealand calls it. ${ }^{100}$ Furthermore, within this placement some children may need professional psychological support. In this context it is also necessary to take objective needs into account.

As already mentioned above, one problem could be the attitude of the new caregivers if they do not hold on to the relationship with the placed child. This not only means that the child needs support, but that the caregivers should also be reminded of the importance of their role and psychologically supported to avoid breakdowns in the relationship between them and the child.

95 Nicola Atwool "Participation in Decision-making: The Experience of New Zealand Children in Care" (2006) 3 Child Care in Practice 259 at 265.

$96 \quad$ At 266.

97 That a child is "in need of care and protection" pursuant to s 14 of the Children, Young Persons, and Their Families Act is prerequisite for a declaration under s 67 of the Children, Young Persons, and Their Families Act. This in turn is a requirement for any court order under Part 2 of the Act, including services orders, custody orders, support orders or guardianship orders. See below chapter V A 3 (b) at 42 for several cases when a child is in need of care and protection. The Children, Young Persons, and Their Families Act 1989 also mentions in s 14 other cases when a child or young person is in need of care and protection.

$99 \quad$ See above chapter IV B at 12. See below chapter V D at 75. 


\section{E Contact Issues}

Another controversial issue concerns contact with the birth family. The key difference between a permanent placement and adoption is that within the process of permanent placement the legal relationships remain whereas they are detached in the context of adoption. So the question is, if legal kinship remains, should the child know the birth family, and, furthermore, how intense should possible contact be? Some research shows that the child's need for belonging in foster placements is often insufficient, ${ }^{101}$ so "a need for connectedness to birth parents, siblings or extended family remains pivotal."102

The question of whether ongoing contact with the birth parents should be permitted or not cannot be answered generally. First of all, the child's welfare and best interests have to be considered. This is not only a question which affects the parents and the caregivers. The short-term effects as well as the long-term interests have to be taken into account determining the child's welfare and best interests. Furthermore, the child's identity and the knowledge of origin are important factors as well. Nonetheless, special circumstances can require that the natural parents' contact with the child has to be prohibited or, at least, suspended. This could be the case where the child suffers disadvantageous effects while in their care. On the other hand, contact with the birth parents could be useful in the long run in securing the relationship between the birth parents and the child, and therefore it can be argued that minimal detriment caused by this contact should be tolerated.

However, there might be situations in which possible contact would be detrimental. In Ministry of Social Development $v C$ a child, aged nearly 6-years-old, was removed from the care of her mother at the age of 13 months and placed with kinship caregivers. ${ }^{103}$ The main issue in this case was the contact the child should have with her father. Judge Ryan dismissed the application of the father for a parenting order providing him with day-to-day contact. Instead the father was allowed to see his daughter twice a year and have contact by letter. Judge Ryan stated that: ${ }^{104}$

... she deserves to have a positive relationship with both of her birth parents but any contact needs to be done in such a way as to not jeopardise the security of her placement ....

... [The] paramount consideration for this child is to ensure that the current arrangement with [her caregivers] continues and that this placement is supported totally. No access arrangement should be contemplated that is likely to undermine the placement.

\footnotetext{
101 Susan Smith "Protection and identity: Finding the right balance to belong" (2012) 7 NZFLJ 124 at 126.

102 At 126

103 Ministry of Social Development v C FC North Shore FAM-2005-004-001166, 19 February 2010.

$104 \quad$ At [15], [16].
} 
The girl may want to reinstate contact and a relationship with her father at a later stage in life. ${ }^{105}$ If this is the case, the judgment would not prevent this. However, the decision made by Judge Ryan was based on the wellbeing of the child. In his mind, contact would be traumatising: ${ }^{106}$

The child's immediate reaction was fear which developed ... into a fear of her father and in particular a fear of being abducted by him. In fact it appears the most recent nightmare featured what were clearly the child's mother and father sneaking into her house with a view to removing her.

Another point which has to be considered is the parental attitude. When talking about permanent placements, one ambition is the establishment of a secure and family-like relationship between the caregivers and the child. This is connected with the opportunity to develop a psychological attachment and a sense of belonging. The efforts of litigious parents to have contact with their child can be distracting. If the establishment of a secure relationship is prevented because parents are unable to accept the current situation, contact between the parents and the child should be limited as well. A prolonged disturbance of the relationship between the caregivers and the child is contrary to the welfare and best interests of the child.

Besides contact with the birth parents, staying in touch with other family members can be important for the child. Therefore, even if contact with the birth parents is not appropriate, in some situations contact with members of the extended family such as grandparents or siblings might has to be considered. Aspects regarding the Māori point of view will be examined in a special section below. ${ }^{107}$ However, it can be stated that any contact with parents or other family members must be beneficial for the child. ${ }^{108}$ In the end, contact to the birth family must be congruent with the purpose of a permanent placement. ${ }^{109}$

\section{F $\quad$ Needs versus Rights}

Seeing children as immature and incompetent is used to justify their exclusion from the decisions-making process and the assumption that adults should decide what is best for children. Atwool sees a distinction between needs and rights as "a key to challenging the

\footnotetext{
105 Ministry of Social Development v C FC North Shore FAM-2005-004-001166, 19 February 2010 at [19]. At [8].

See below chapter V C at 72 .

Family Law Service - Children, Young Persons, and Their Families (online looseleaf ed, LexisNexis) at $[6.578]$.

109 Allan Cooke "Contact Issues for children who have been permanently placed out of their birth families" (2009) 6 NZFLJ 176 at 180.
} 
deficit model of childhood". ${ }^{110}$ To her mind "the concept of needs fits well with a deficit model of childhood" and a welfare approach that focuses on the needs rather than on the rights is able to disempower the child. ${ }^{111}$ In order to overcome the antiquated concept of childhood it is necessary to recognise the needs, but, furthermore, to acknowledge and strengthen the rights of the child.

The distinction between needs and rights is a good starting point to bring light to the dark maze of definitions of childhood, children themselves and children's abilities. Firstly, it has to be recognised that children are not a homogenous group. ${ }^{112}$ They differ in their abilities, and are motivated by their various ages and social and cultural backgrounds. However, some essential needs for survival that can be identified are the same no matter the child. James and James distinguish between three different types of needs: ${ }^{113}$

There are psychological and social needs that are rooted in our nature as social animals ... [Children] have special physical needs in terms of nutrition, clothing and health care; special social needs in terms of schooling, socialisation and moral development; and special psychological needs in terms of protection, nurturing and attachment.

Furthermore, it is stated that these needs were transferred to rights because of the United Nations Convention on the Rights of the Child. ${ }^{114}$ James and James mentioned that critics see a weakening of the rights by the mechanism for their enforcement. ${ }^{115}$ So the inclusion of the various needs into a legal statute could be a step back in protecting and promoting children.

It is possible that the general granting of several rights by the United Nations Convention on the Rights of the Child has shifted the focus of attention. This does not lead to a weakening of the rights and position of the child overall - a statement I do not agree with. Some rights are essential, so essential that they should not be questioned, whether codified or not. In addition, several rights might not be or even cannot be codified and arise out of the fact of human existence itself. The right to life, the right to personal freedom, the right to personal integrity, the right of personality and the right to participate are some of these basic rights. The principle of equality and the principle to be treated with respect and tolerance are fundamentals as well.

\footnotetext{
110 Nicola Atwool "Participation in Decision-making: The Experience of New Zealand Children in Care" (2006) 3 Child Care in Practice 259 at 263. At 263.

112 Allison James and Adrian James Key Concepts in Childhood Studies (Sage Publications Ltd, London, 2008) at 34.

113 At 87 (emphasis added).

$114 \quad$ At 87.

115 At 111 .
} 
Children are entitled to these objectives to the same extent as adults, or, at least, should be. The fact that children are not able to care for themselves, and the logical conclusion that those who bear responsibility for their existence have to fill in for this lack of capability initially in their favour, does not remove any of these rights. Keeping this in mind, children may be vulnerable and in need of protection, but, on the other hand, have rights like everyone else and should be treated accordingly: as full members of the human family.

\section{G Summary}

This dissertation places a clear and profound emphasis on the child. The child's rights and needs are the linchpin, keeping in mind that the starting-point has to be the individual child in his or her specific circumstances. Every child is an individual with complex needs, has multiple rights and is vulnerable, but is a full member of the human family and has to be treated as such.

The welfare and best interests of the child must be paramount. The rights or interests of the birth parents are subordinate. A decision should not be taken only to be equitable to birth parents. However, defining welfare and best interests is not possible. The concept itself is shaped by vagueness and therefore greatly in need of interpretation. Several other principles might be helpful to give a shape to this indefinite legal term. These identified objectives are based on the idea of offering every child similar conditions and the opportunity to grow up in a harmonious family environment, shaped by happiness, love and understanding, the possibility to develop an individual personality and to be prepared to live his or her individual life in society. Therefore it is important to create a secure and permanent placement. However, the welfare and best interests of the child should only be paramount or the first consideration, if this is determined from the child's point of view.

In addition, it should be kept in mind that children have rights as well. The idea of children as the property of their parents was indeed overcome long ago. However, because of their inability to care for themselves their rights might still be curtailed and they are not seen as entire legal subjects.

Therefore, in every decision-making process the child should have the possibility to participate. Furthermore, in personal matters it must be assumed that the child is competent and adults should have to demonstrate that the child is not able to make a decision. In this case, overruling the rights of the child can be justified. Decisions made in this realm of law should concentrate on the child and his or her rights. "In the past social work has been characterised by a 'welfare' approach that tends to emphasise needs rather than rights, 
disempowering the child." ${ }^{116}$ In order to overcome this it is necessary to consider the needs and rights and other principles equally - in the light of special circumstances. To pre-weigh one factor will not lead to satisfactory outcomes. We would never deny "basic rights" of humans because of gender, race, religion or origin. But based on age? At the very least a special justification should be necessary.

However, even while acknowledging that "belonging comes from relationships, not legal mechanisms as such", ${ }^{117}$ legal provisions that give those concerned, especially the child, the feeling of security and belonging, are required.

One of the purposes of the new guardianship order introduced in the White Paper is to address the specific needs for ongoing security. Ongoing security is part of the achievement of permanency. Furthermore, the White Paper states that "the child's voice, wishes and feelings will be a central part of the care planning, in addition to those of their family/whānau." 118 It does not explain in detail how the child should participate when it comes to the limiting of parental rights. There it is incomplete.

\footnotetext{
116 Nicola Atwool "Participation in Decision-making: The Experience of New Zealand Children in Care" (2006) 3 Child Care in Practice 259 at 263.

117 Susan Smith "Protection and identity: Finding the right balance to belong" (2012) 7 NZFLJ 124 at 126

118 Paula Bennett, Ministry of Social Development "The White Paper for Vulnerable Children" (Wellington, 2012) volume II at 121.
} 


\section{Legal Issues and Practice}

Since time immemorial, there has been a societal assumption that children are best cared for by their biological parents: ${ }^{119}$

From the numerous cases on custody which have come before Courts over the years it has been established that there is a prima facie presumption that it is for the benefit of the child that he or she should be in the custody of the natural parents ...

However, in cases of children permanently placed in the care of foster parents this presumption may no longer exist. Furthermore, the responsibility is transferred to the new caregiver. Based on the welfare and best interests of the child, the newly created relationship between foster parent and child must receive as an equally a strong protection by the law as the natural parent-child relationship. Anything less would jeopardise the placement and the relationship between child and foster parent and thus, not least the child's welfare. Of course, this approach is based on the assumption that the blood tie cannot be such a strong consideration as it seemed to be and that the so-called right of a parent to care for his or her own child is not a right in a legal sense.

The emerging questions which have to answered are: How can the role of foster parents in a case of a permanent placement be defined? What is the existing legal framework to secure the relationship between foster parents and child? What rights and responsibilities remain for birth parents? Are the existing rules sufficient to allow a secure upbringing for the benefit of the child's welfare?

\section{A The Care of Children Act and the Children, Young Persons, and Their Families Act}

Two different New Zealand statutes are relevant. The first statute is the Care of Children Act 2004, which deals with the legal relationship between children and parents. Furthermore, it contains rules for those who act instead of the birth parents if the child is living with someone else instead. The Act provides the possibility of making guardianship and parenting orders.

The second statute is the Children, Young Persons, and Their Families Act 1989 which provides the legal basis for an intervention by the state if a child is in need of care and protection. ${ }^{120}$ The most drastic and therefore final action to be taken is the removal of the

\footnotetext{
$119 \quad \operatorname{Re} D$ (An infant) [1971] NZLR 737 at 740-741.

120 The provisions in the Children, Young Persons, and Their Families Act 1989 apply to a child or a young person. Child is defined by s 2 of the Act as a boy or girl under the age of 14 years. Young person means a boy or girl over the age of 14 years but under 17 years, but does not include any person who is or has been married or in a civil union. For ease of readability the text uses only the term "child". This also refers, however, unless otherwise indicated, to the young person.
} 
child from the birth family and placing the child in alternative care. Possible orders under this Act in relation to the removal and placement of a child are guardianship and custody orders.

The reasons for a removal may be of different nature. There may be cases where a child lives with new caregivers because of an agreement as well as cases where the removal occurred because the child was in danger.

\section{$1 \quad$ General statements about the two statutes}

The purpose of the Care of Children Act is to promote the welfare and best interests of the child and facilitate the development. ${ }^{121}$ Therefore, it not only defines and regulates the parent's rights and responsibilities, but also contains the court's powers in relation to guardianship and care of a child. ${ }^{122}$ For Child, Youth and Family it is the prioritised statute to secure the relationship between child and caregiver. ${ }^{123}$ Under s 3(1)(a), the purpose of the Act is to be achieved by helping to ensure that appropriate arrangements are in place for the child's guardianship and care. Furthermore, according to s 3(1)(b), the rights of the child have to be recognised and in conjunction with s 6(2) the views of the child have to be considered as well.

Permanency under the Care of Children Act can be achieved by making parenting orders under s 48 in favour of the new caregivers or/and appointing them either as additional or as sole guardians pursuant to $\mathrm{s} 27$. Once such an order is made it is in this respect permanent that the Act does not provide for a regular review. ${ }^{124}$ A person affected by the order or a person acting on behalf of the child pursuant to s 56(3) has got the right to apply to vary parenting orders or, pursuant to s 29 , guardianship orders. ${ }^{125}$

The other important statute containing the specific framework regarding the placement of a child is the Children, Young Persons, and Their Families Act. This Act provides the legal basis for state intervention, if a child is in need of care and protection as defined in $\mathrm{s} 14$ of the Act.

Security for the child or permanency is provided by custody orders pursuant to s 101 and additional or sole guardianship orders pursuant to s 110(2). However, the birth parents remain guardians with the appropriate rights and responsibilities. Pursuant to s 11(2)(a) the rights, powers and duties of the parents will only be suspended where the court appoints another

\footnotetext{
$121 \quad$ Care of Children Act, s 3(1)(a).

122 See Care of Children Act, s 3(2)(a).

123 See Child, Youth and Family "Use of Legal Orders to secure a home for life" (May 2011) <www.practicecentre.cyf.govt.nz>.

124 Stephen Coyle "Permanency Policy: children in care" (2008) 6 NZFLJ 45 at 46; Child, Youth and Family "Use of Legal Orders to secure a home for life" (May 2011) <www.practicecentre.cyf.govt.nz>. See below chapter V A 6 at 62.
} 
person as sole guardian. Birth parents remain guardians - with (suspended) rights - as long as they are not removed by an order under the Care of Children Act. Moreover, the achieved security can be disturbed by any person making an application for variation or discharge of the orders made. ${ }^{126}$ This can undermine the secure base within the new family. "Thus the need for care and protection [of the child] will ordinarily extend to protection of the child by protecting the integrity of that permanent placement." 127

The application of these statutes may be unclear in some borderline case. While the Children, Young Persons, and Their Families Act deals with guardianship and custody in cases where the child is in need of care and protection pursuant to s 14, the Care of Children Act is applicable in a more generic way. The Children, Young Persons, and Their Families Act "is a public law statute concerned to direct the resources of the state to ensure the protection of children who are subject to abuse or neglect within their family." ${ }^{128}$ On the other hand, the Care of Children Act "is part of private law and is primarily concerned with the appointment of, and disputes between, guardians." 129

However, a case which was first dealt with under the Children, Young Persons, and Their Families Act may fall under the Care of Children Act after the passage of time and after the circumstances changed. In $E v G$, for example, the foster parents filed applications to discharge custody and guardianship orders under the Children, Young Persons, and Their Families Act and to replace them with a parenting order and a guardianship order pursuant to s 27 of the Care of Children Act. ${ }^{130}$ According to Judge Callinicos "only where the Court is satisfied that the child's situation will not be subject of ongoing care and protection issues ... orders should fully transition to COCA." ${ }^{131}$ Finally, the Judge made a parenting order pursuant to s 48 of the Care of Children Act in favour of the foster parents, appointed them as additional guardians pursuant to s 27 and ruled that access or contact with the birth father had to continue under the Children, Young Persons, and Their Families Act. ${ }^{132}$ So in some cases courts see the application of both statutes as appropriate to protect the security of a placement. ${ }^{133}$ However, it can be questioned whether this is a good way to deal with the matter. Both Acts have different requirements to be met to make a court order. Furthermore, this can lead to several questions regarding review and variation as well as discharging the orders. It may complicate the legal process more than necessary. Would it not be more

\footnotetext{
126 Children, Young Persons, and Their Families Act, s 125(1)(f) and (g)

$127 \quad$ Allan Cooke "Permanency for children: why permanently placed children need ongoing support, and how to deliver that support" (2008) 6 NZFLJ 37 at 39.

128 Brookers Family Law - Care and Protection (online looseleaf ed, Brookers) at [NT1.2.10].

$129 \quad$ At [NT1.2.10].

$130 \quad E v G$ [parenting orders] 2008 NZFLR 337 at [20].

$131 \quad$ At [31]

132 See $E v G$ [parenting orders] 2008 NZFLR 337 at [151], [155], [160].

133 See Brookers Family Law - Care and Protection (online looseleaf ed, Brookers) at [NT1.2.10].
} 
sensible to deal with a case only under one Act or another, having regard to the prerequisite whether a child is in need of care and protection?

In $\operatorname{Re} B$ (children) the protection proceedings were adjourned, because the parents sought custody according to the Guardianship Act 1968, which would have resolved the protection proceedings. ${ }^{134}$ There are also cases where, at first, the matter was dealt with under the Care of Children Act and later orders under the Children, Young Persons, and Their Families Act had to be made. ${ }^{135}$

This dissertation focuses on the legal possibilities provided by both statutes to secure the placement of a child. To avoid repetition, the two statutes are examined together in the next sections. Even with potential differences, both statutes must be interpreted as a whole, since they act reciprocally. Some of the principles in both Acts mirror each other. ${ }^{136}$ The decisions and orders to make relate to the same child and the goal is the same: to create a secure placement to grow up. ${ }^{137}$

In the following sections, firstly, the decision-guiding principles are examined. Secondly, guardianship as the general legal concept for a parent-child relationship is discussed: Birth parents are natural guardians and a third party can become a court-appointed guardian, but what does this mean? Where foster parents become guardians, what rights do they have? How can they be appointed? What does this mean for the birth parents as guardians? Thirdly, parenting orders are in the focus. They can be used to transfer the exercise of rights in regard to the child to a third party. So, often foster parents will apply for such an order to achieve a legal position in regard to their foster child. Where more than one party has a right to decide and they cannot find a solution a dispute resolving possibility has to be available. The examination of the provisions to resolve disputes is followed by part five dealing with the possibilities, for example, birth parents have to challenge court orders in favour of permanent caregivers.

\footnotetext{
$134 \quad \operatorname{Re} B$ (children) [1992] NZFLR 729 at 727.

135 Tracy Gunn "Review of practice relating to representing clients in proceedings under the Children, Young Persons, and Their Children Act 1989" (New Zealand Law Society Care and Protections Orders and CYFS Seminar, Wellington, 25 October 2012); according to s 19(1) of the Children, Young Persons, and Their Families Act, where any body or organisation or court concerned with the welfare of the child believes that the child is in need of care and protection this organisation may refer the matter to a care and protection co-ordinator, so further investigation can take place.

$136 E v G$ [parenting orders] 2008 NZFLR 337 at [52].

137 The unclear application of the statutes in some cases may cause difficulties and insecurity. The White Paper talks about amending the Children, Young Persons, and Their Families Act. This may not resolve the problem. See also discussion below in chapter VII A 5 at 92.
} 
The following section examines the contained principles. Both statutes know the welfare principle. In addition, the statutes comprehend several other principles to guide the decisionmaking process. They are examined separately.

(a) The welfare and best interests

The welfare and best interests of the child as a key principle can be found in s 4 of the Care of Children Act: ${ }^{138}$

The welfare and best interests of the child must be the first and paramount consideration in the administration and application of this Act, for example, in proceedings under this Act: and in any other proceedings involving the guardianship of, or the role of providing day-to-day care for, or contact with, a child.

Declaring that the welfare and best interests must be paramount does not abolish the difficulties of definition. The statute itself does not define this legal term. Therefore, it seems not unreasonable to rely on the above attempt of definition. In addition, in $G v G$ Richmond $\mathrm{P}$ and Richardson J stated: ${ }^{139}$

The wellbeing of the children is the first and paramount consideration. An overall view must be taken. Undue emphasis must not be given to material, moral or religious considerations, or for that matter any other factor. All aspects of welfare must be taken into account and that will include consideration of the child's physical and mental and emotional wellbeing and the development in the child of standards and expectations of behaviour within our society.

Furthermore, in $J v C$ Lord MacDermott already determined what first and paramount consideration means: ${ }^{140}$

[It] seems to me that they must mean more than that the child's welfare is to be treated as the top item in a list of items relevant to the matter in question. I think they connote a process whereby, when all relevant facts, relationships, claims and wishes of parents, risks, choices and other circumstances are taken into account and weighed, the course to be followed will be that which is most in the interests of the child's welfare as that term has now to be understood. That is the first consideration because it is of first importance and the paramount consideration because it rules on or determines the course to be followed.

\footnotetext{
$138 \quad$ Care of Children Act 2004, s 4(1).

$139 G v G[1978] 2$ NZLR 444 at 447 per Richmond P and Richardson J.

$140 \quad J$ and Another $v C$ and Others [1969] 1 All ER 788 at 820-821 per Lord MacDermott.
} 
Section 5 contains several principles, which are relevant for the welfare and best interests of the child and which are examined in the next section.

However, according to $\mathrm{s} 4(2)$ the welfare of the specific child has to be taken into account and not a generic child or general circumstances. Furthermore, s 4(3) declares that the parent's conduct may only be considered as far as it is relevant to the child's welfare and best interests, which, for example, would be relevant when it comes to questions of abuse or neglect and contact issues. ${ }^{141}$

Determining what accommodates the child's welfare best, it has to be taken into account "that decisions affecting the child should be made and implemented within a time frame that is appropriate to the child's sense of time". ${ }^{142}$

Also the Children, Young Persons, and Their Families Act contains the welfare principle, stating in 6 that: ${ }^{143}$

In all matters relating to the administration or application of this Act ... the welfare and best interests of the child ... shall be the first and paramount consideration, having regard to the principles set out in sections 5 and 13 .

Again, the welfare is the first and paramount consideration. It cannot be defined in another way as in relation to the Care of Children Act. However, the Children, Young Persons, and Their Families Act contains in ss 5 and 13 several principles which should be taken into consideration. Nevertheless, welfare is to be treated as paramount.

(b) Other principles in s 5 of the Care of Children $\mathrm{Act}^{144}$

Section 5 contains several principles relevant to the child's welfare and best interests. ${ }^{145}$ Hence, their consideration is mandatory and these objectives must be kept in mind. ${ }^{146}$ Section $4(5)(b)$ refers to them stating that: ${ }^{147}$

\footnotetext{
141 See also Temple v Barr and Holborn HC Wellington CIV-2010-485-000561, 24 August 2010 at [29].

142 Care of Children Act 2004, s 4(5)(a).

143 Children, Young Persons, and Their Families Act 1989, s 6.

144 The Family Court Proceedings Reform Bill 2012, introduced in October 2012, replaces s 4 and s 5. The child's safety, for example, is the first mentioned principle. However, it does not introduce new principles.

145 Section 4(5)(b) of the Care of Children Act 2004 refers to them stating that: In determining what best serves the child's welfare and best interest, a court or a person must take into account any of the principles specified in section 5 that are relevant to the welfare and best interests of the particular child in his or her particular circumstances.

146 Temple v Barr and Holborn HC Wellington CIV-2010-485-000561, 24 August 2010 at [30].

147 Care of Children Act, s 4(5)(b).
} 
In determining what best serves the child's welfare and best interest, a court or a person must take into account any of the principles specified in section 5 that are relevant to the welfare and best interests of the particular child in his or her particular circumstances.

Even though these principles can "never dictate the outcome given the infinite variety of the relevant circumstances surrounding", because of their consideration by any court they "must lead to orders and conditions."

The principles in s 5 overlap each other at some point and are not backbreaking in determining the welfare of the individual child having regard to the special circumstances of each case. ${ }^{149}$ Furthermore: ${ }^{150}$

The policies contained in the principles are optimum policies. Circumstances in some cases will prevent their application. ... But in situations where the optimum policies of relevant principles are in place ... it is vital and indeed mandatory for a court to factor on and weigh them in the exercise of relevant judicial discretions.

Nevertheless, they provide good evidence to make a decision for the benefit of the child's welfare. Even though the principles are self-evident, it seems to be appropriate to discuss them in more detail. ${ }^{151}$

\section{(i) Principles in detail}

The first principle contained in s 5(a) states that the child's parents and guardians should have the primary responsibility. ${ }^{152}$ This principle applies not only to the birth parents, but also includes psychological parents or in other words: "a father or mother figure with whom a child has bonded over a period of time". ${ }^{153}$ One of the questions discussed in this dissertation is the relation between parents and permanent caregivers, their rights and duties. However, someone has to be responsible. The question to answer is, at least, who this person should be, if the parents fail to do so. Important to note is that "the s 5(a) principle does not confer rights on parents which can be enforced and pursued to the detriment of the paramount consideration of a child's welfare." 154

\footnotetext{
$148 \quad$ Tanner $v$ Edgill [2008] NZFLR 262 at [30].

149 Temple v Barr and Holborn HC Wellington CIV-2010-485-000561, 24 August 2010 at [30].

$150 \quad$ Tanner $v$ Edgill [2008] NZFLR 262 at [31].

$151 \quad$ At [31]

152 See also Family Court Proceedings Reform Bill 2012, clause 4. This principle can be found in new s 5(b).

153 Temple v Barr and Holborn HC Wellington CIV-2010-485-000561, 24 August 2010 at [30] (emphasis added).

$154 \quad K v G$ [2004] NZFLR 1105 at [23].
} 
Secondly, the arrangements for the child's care, development and upbringing should be continual. ${ }^{155}$ Furthermore, Cooke stretches this, stating that "the child has a right to continuity in care, development and upbringing". ${ }^{156}$ This supports the approach of this dissertation that permanency is an important principle in the life of the child concerned and is necessary to promote the welfare and best interests of a child. It needs to be investigated whether the regulations contained in the Care of Children Act and the suggestion in the White Paper and their application meet this approach. In determining the child's welfare, not only the relationship between birth parents and child is an important factor. The wider family has to be considered. In addition, s 5(b) also declares that:

... the child's relationship with his or her family, family group, whānau, hapū, or iwi should be stable and ongoing (in particular, the child should have continuing relationships with both or his or her parents).

The parentheses shows the importance of the relationship between parents and child. On the one hand, it is in the interests of the child to know his or hers origin and, on the other hand, it gives expression to the special status parents have in their child's life. It does not mean that the relationship between parents and child is a predominant factor, especially, if the child's welfare is endangered by them. However, the Pākehā concept of a nuclear family consisting of father, mother and child is rejected by this section. ${ }^{157}$

It can be stated that the principle in s 5(a) and the principle contained in $s 5(b)$ at the end indicate that the parents are responsible for their child in the first instance and an ongoing relationship between child and parents serves the child's welfare. In any case this should not be interpreted in such a way as "parents have some innate right or entitlement to the care of their children or that placement with parent will be presumed to serve the child's welfare and best interests." ${ }^{\prime 158}$ Considering welfare as paramount there is no space for a right of parents to care for their child, if they endanger the welfare. This does not mean that parents are not or should not be responsible in the first place.

Related to this, s 5(c) states that the care and upbringing of the child should be facilitated by ongoing consultation and co-operation between and among parents and guardians and all persons exercising the role of providing day-to-day care. ${ }^{159}$ "All persons exercising the role of providing day-to-day care" includes even on a literal interpretation the new caregivers

155 Care of Children Act, s 5(b); see also Family Court Proceedings Reform Bill 2012, clause 4. This principle can be found in new s $5(\mathrm{~d})$.

156 Allan Cooke "Contact Issues for children who have been permanently placed out of their birth families" (2009) 6 NZFLJ 176 at 179.

157 PED v MHB [Whangai: Final Parenting order] [2012] NZFLR 35 at [26].

158 Brookers Family Law - Child Law (online looseleaf ed, Brookers) at [CC48.15 (4)].

159 See also Family Court Proceedings Reform Bill 2012, clause 4. This principle can be found in new s $5(\mathrm{c})$. 
because they are responsible for the actual care. Nevertheless, in PED v MHB [Whängai: Final Parenting order] it was stated that s 5(c) "should be given an expansive interpretation to include psychological parents." "160 The linchpin of this dissertation is the existing practice that the new caregivers share their responsibilities with the birth parents or the chief executive. The former situation could be problematic depending on the behaviour of the birth parents and their acceptance of the new care situation. Undermining the new placement of the child impedes the care and upbringing and is consequently contrary to the welfare and best interests of the child. Therefore it might be necessary to take the parents' guardianship away.

The relationship between the child and members of his or her family, family group, whānau, hapū or iwi should not only be stable and ongoing as s 5(b) declares, it should also be preserved and strengthened. ${ }^{161}$ This means the relationship should not only be maintained, but steps should also be taken to develop the child's relationship with the wider family. ${ }^{162}$ Furthermore, the child's identity, which includes its origin, should be preserved and strengthened. ${ }^{163}$

In this context the difficult question of contact with the birth family, the nuclear family as well as the wider family, arises. The Care of Children Act places an emphasis on the origin of the child as part of his or her identity, dealing with related matters in three different subsections. However, it is debatable to what extent contact with the birth family should be enabled. ${ }^{164}$

Another principle relevant to the welfare is the child's safety, which has to be protected, contained in s 5(e). A difference to all the other principles can be found in the wording: "the child's safety must be protected and, in particular, he or she must be protected from all forms of violence". ${ }^{165}$ This clarifies the obligation to protect the child's safety. ${ }^{166}$ "All forms of violence" includes, of course, physical and sexual violence, but: ${ }^{167}$

$\ldots$ is wide enough to require protection from witnessing or being involved in an environment where violence is likely to be observed and in that way impose suffering upon the child.

160 PED $v$ MHB [Whangai: Final Parenting order] [2012] NZFLR 35 at [30].

161 Care of Children Act, s 5(d); see also Family Court Proceedings Reform Bill 2012, clause 4. This principle can be found in new s 5(e).

162 PED $v$ MHB [Whāngai: Final Parenting order] [2012] NZFLR 35 at [32]

163 Care of Children Act, s 5(f); see also Family Court Proceedings Reform Bill 2012, clause 4. This principle can be found in new s 5(f).

164 See above chapter IV E at 20 and below chapter V A 4 (b) at 57 as well as chapter VII C at 93.

165 Care of Children Act, s 5(e) (emphasis added).

166 Temple v Barr and Holborn HC Wellington CIV-2010-485-000561, 24 August 2010 at [30].

167 At [30]. 
Any decision that places the child in danger, either emotionally, psychologically or physically, has of course to be omitted and cannot meet the welfare and best interests of the child.

(ii) Weighting as between principles

The questions which arises in determining the welfare and best interests of the child with reference to the named principles is, whether there is a priority between them. In Kacem v Bashir the Supreme Court had to deal with this question. ${ }^{168}$ The majority of the Supreme Court held that there has to be a focus on the particular circumstances of every special case. ${ }^{169}$ However, there is "no presumption of what the welfare and best interests of the child may require or what influence the s 5 principles may have". ${ }^{170}$ Neither the wording nor the structure of s 5 set out that one principle should be more important than another. ${ }^{171}$ Furthermore: ${ }^{172}$

The bracket portion of principle (b), containing as it does the words "in particular", creates internal emphasis within principle (b). It does not signal that any aspect of principle (b) has presumptive emphasis or priority as against the other lettered principles in $\mathrm{s} 5$.

Every principle has to be examined and if it is relevant it has to be taken into account. George states that the "... judges are reminded clearly that they must not pre-weigh any factor that is relevant to their decision." ${ }^{173}$ The paramount consideration is the welfare and best interests of the child. All principles are of assistance for interpretation. In every special case one principle will be more important than another. However, this does not lead to the conclusion that one principle stands above all others. "[E]ach factor must be considered on the specific facts of the case and not pre-weighed based on generalisations". ${ }^{174}$ Most notably, "promoting strong parent-child relationships is not presumptively more important than promoting children's welfare and best interests in other ways." ${ }^{175}$ Furthermore, the principles in 55 are not exhaustive. ${ }^{176}$ So how could one of them carry determinant weight? It is said in Kacem v Bashir that principle 5(e) occupies a special position because of the word "must". ${ }^{177}$ Anyway, the child's safety is a factor which should always be borne in mind making a decision on behalf of a child. To my mind this is a matter of course.

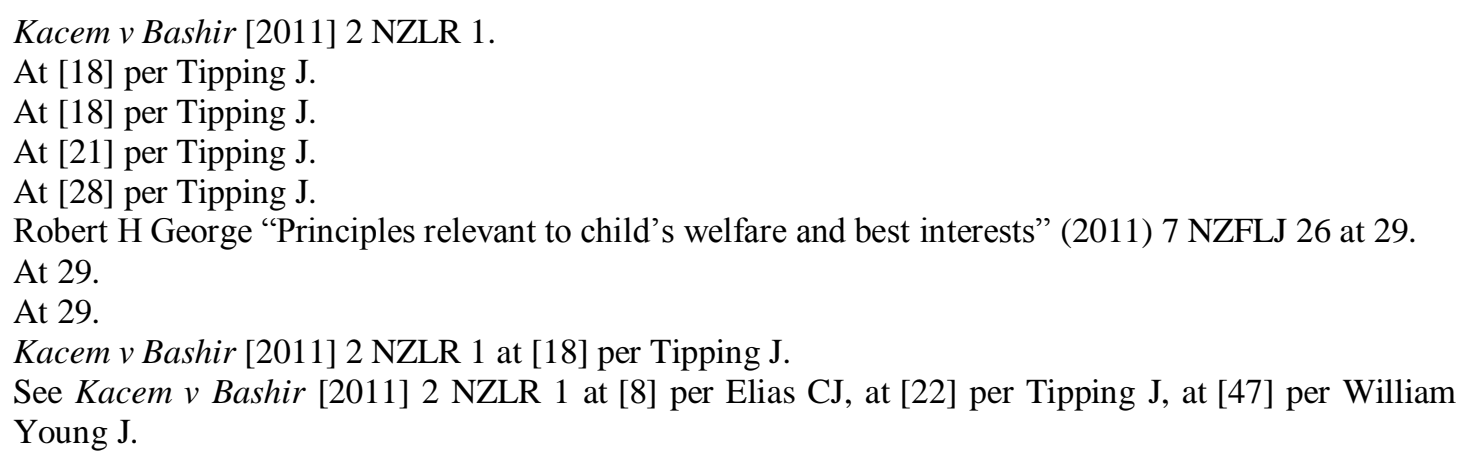


This decision only refers to the Care of Children Act. Anyway, a more general approach can be educed. The welfare is the paramount principle. Any other objective in the legislation cannot be decisive. They may only be assistance to determine and serve the child's welfare.

(iii) Applying to the Children, Young Persons, and Their Families Act

An interesting fact is that both statutes presume the welfare and best interests to be the paramount consideration, but only the Care of Children Act provides a set of principles to clarify the undefined legal term. The Children, Young Persons, and Their Families Act also contains a list of principles that have to be considered in exercising the powers the Act confers. However, they are not meant to clarify welfare and differ from the ones in the Care of Children Act. The question is whether or not the principles contained in the Care of Children Act should apply to the Children, Young Persons, and Their Families Act.

First, this question would have to be answered in the negative, if the principles do not contribute in a positive way, but are not more than a list of confusing concepts. As stated, the welfare principle is a vague term and this is, on the one hand, necessary to have regard to the different situations the law has to deal with, but, on the other hand, brings uncertainty, which is, especially in law, a negative factor. Therefore, a list of guiding principles helping to define the welfare of a child is a useful step to more certainty. This list cannot be conclusive and the several principles can never have equal weight in every case. However, having provisions to define the welfare also mean that this legal term has to be interpreted equally.

Second, even though both statutes are part of different realms of law, the legal system itself must be uniform. The child's welfare should not have a different meaning in the Children, Young Persons, and Their Families Act from the Care of Children Act. It must be interpreted in the same way: it is the same child. Therefore, the list of principles relevant for the welfare should apply to the Children, Young Persons, and Their Families Act, and also the other way around. In FMHM \& Anor $v$ JJMP \& Ors Judge Ryan took the view that: ${ }^{178}$

It would be a ludicrous state of affairs for [the principle of s 13 of the Children, Young Persons, and Their Families Act] to be taken into account whilst a child was under the care and protection provisions of the Children, Young Persons, and Their Families Act and yet ignore them simply because the care and protection orders are discharged and the Care of Children Act comes into play. 
(c) Principles in the Children, Young Persons, and Their Families Act

In the Children, Young Persons, and Their Families Act principles are also contained, which should be considered. Section 6, stating that the welfare is the paramount consideration, is subject to ss 5 and $13 .{ }^{179}$

\section{(i) Principles of section 5}

Section 5 contains principles which should be applied in exercise of powers conferred by the Act. The Act could be seen as the "general framework for working with families". ${ }^{180}$ Firstly, wherever possible the child's family, whānau, hapū, iwi and family group should participate in the decisions making affecting the child and regard should be had to the views of that family. ${ }^{181}$ Secondly, wherever possible the relationship between the family, whānau, hapū, iwi and family group and the child should be maintained and strengthened. ${ }^{182}$ This may be compared with the provisions in s 5(d) of the Care of Children Act. In addition, s 7(2)(c)(iv) states that:

In carrying out the duty imposed by subsection (1), the chief executive shall ensure, wherever possible, that all policies adopted by the department, and all service provided by the department, avoid the alienation of children ... from their family, whānau, hapū, iwi and family group.

This means the relationship between the child affected and the birth family should be maintained. This, of course, has to be consistent with the child's welfare.

Thirdly, it must be considered how a decision will affect the child's welfare and the stability of the child's family, whānau, hapū, iwi and family group. ${ }^{183}$ It should be noted that the wording of s 5(c) - must - indicates again that the child's welfare is the first and paramount consideration in exercising the court's jurisdiction. ${ }^{184}$

However, s 5 itself shows the paramountcy of welfare. On the one hand, s 5 declares that the "family group should participate"(s 5(a)), the relationship between child and family "should be maintained and strengthened" (s 5(b)), "consideration should be given to the wishes" (s 5(d)) and decisions "should, whenever possible, be made" within an appropriate timeframe (s 5(e)). ${ }^{185}$ On the other, s 5(c) requires that "consideration must always be given to

\footnotetext{
$179 \quad \operatorname{Re} B$ (children) [1992] NZFLR 726 at 757; Ev G [parenting orders] 2008 NZFLR 337 at [39].

180 Allan Cooke "Contact Issues for children who have been permanently placed out of their birth families" (2009) 6 NZFLJ 176 at 177.

181 Children, Young Persons, and Their Families Act 1989, s 5(a).

182 Section 5(b).

183 Section 5(c).

$184 \quad \operatorname{Re} B$ (children) [1992] NZFLR 726 at 757.

185 Emphasis added.
} 
how a decision ... will affect (i) the welfare of the child" and, in addition, according to s 6 "... the welfare and interests of the child ... shall be the first and paramount consideration...". ${ }^{186}$ Comparing the statutory words it is conspicuous that both wordings have a more imperative character: ${ }^{187}$

It is quite clear that within ss 5, 6 and 13 a plain distinction is drawn between, on the one hand, matters that ought to be taken into account but which need not in themselves be decisive and, on the other hand, the overriding and paramount principle need to ensure that the result of the exercise benefits the child. In the end every factor has to be judged and tested by the impact it has on the welfare and interests of the child.

\section{(ii) Principles of section 13}

Section 13 expands on the principles contained in ss 5 and $6 .{ }^{188}$ In the context of the care and protection of children s 13 contains several principles which must guide the exercise of any powers conferred by or under Part 2. ${ }^{189}$ The first guiding and supreme principle is the principle that children must be protected from harm, their rights upheld, and their welfare promoted. ${ }^{190}$ The protection of the child's safety can also be found in s 5(e) of the Care of Children Act, as already examined before. The following paragraphs of s 13 contain "guidelines" for intervention. First of all, they state that the primary role for caring and protecting lies within child's family and accordingly the child's family should be supported as much as possible and the intervention should be the minimum necessary. ${ }^{191}$ Such intervention should "be restrained to a level commensurate with that required to protect the safety or welfare of the child." ${ }^{192}$ Furthermore: ${ }^{193}$

... it is desirable that a child ... live[s] in association with his or her family, whānau, hapū, iwi, and family group, and that his or her education, training, or employment be allowed to continue without interruption or disturbance.

If a child is in need of care and protection the child should be cared for and protected within his or her own family, whānau, hapū, iwi or family group and, therefore, the necessary assistance and support should be provided. ${ }^{194}$ "Only if there is a serious risk of harm to the

\footnotetext{
186 Emphasis added.

$187 \quad$ Re B (children) [1992] NZFLR 726 at 757-758.

188 Ev G [parenting orders] 2008 NZFLR 337 at [44].

189 Children, Young Persons, and Their Families Act 1989, s 13, as well as any powers conferred by or under pt 3 or $3 \mathrm{~A}$ or sections 341 to 350.

190 Children, Young Persons, and Their Families Act 1989, s 13(a).

191 Section 13(b); In A v Ministry of Social Development [Access] [2009] NZFLR 625 at [25] it is stated: "The care and protection principles generally do not refer specifically to the biological relationship, but do frequently refer to the family group, involving thereby both biological and psychological relationships."

$192 \quad$ E $v$ G [parenting orders] 2008 NZFLR 337 at [45].

193 Children, Young Persons, and Their Families Act 1989, s 13(c).

194 Section 13(d).
} 
child" the child should be removed. ${ }^{195}$ This shows that the removal of a child should be the last option to protect the child. Even if a child has to be removed, he or she should be wherever practicable returned to and protected within his or her family, whānau, hapū, iwi and family group and where this is not immediately possible the child should live in an appropriate family-like setting, that is in the same locality as that in which the child lived before and in which the child's links with his or her family, whānau, hapū, iwi and family group are maintained and strengthened. ${ }^{196}$ This shows the importance the Act accords to the relationship between the child and the wider (birth) family. The last possible resort to be taken is the permanent removal of the child. The child who cannot be returned to his or her family, whānau, hapū, iwi and family group should live in a new family group. ${ }^{197}$

One of the main objectives which has to be considered in placements outside of the birth families should be to give the child the possibility to experience a "normal" family life. The child should have the opportunity to develop a sense of belonging to a family (group) and a psychological attachment to the carer. This is in s 13(f)(iii). Furthermore, it is stated that in this new family group the child's sense of community and the personal and cultural identity should be maintained. ${ }^{198}$ The White Paper mentions the child's cultural identity as "an important contributor to wellbeing." ${ }^{199}$ However, it focuses more on educational questions and supporting identity in this regard. ${ }^{200}$ Beyond this, it states that children should "get what they need to ensure their ... sense of identity." 201 Unfortunately, the White Paper in this context pays little regard to permanent placements.

The child removed should experience permanency. Cooke goes far further conceding the child a "right to live in an 'appropriate family-like' setting so that a sense of belonging, continuity and personal and cultural identity are maintained" and "a right of the child to be given the opportunity to develop a significant psychological attachment to the person in whose care that child has been placed." 202

Section 13 shows that the Act contains as a basic scheme that the family is responsible if a child is in need of care and protection, and that state agencies should be involved as a last

201 See Paula Bennett, Ministry of Social Development "The White Paper for Vulnerable Children" (Wellington, 2012) volume II at 168.

202 Allan Cooke "Contact Issues for children who have been permanently placed out of their birth families" (2009) 6 NZFLJ 176 at 177 (emphasis added).
} 
resort. ${ }^{203}$ Restoration the child's family is another important issue. However, this does not mean that a family reunification takes priority above the child's welfare and best interests. ${ }^{204}$

Furthermore, Judge Inglis QC stated in Re B (children) that: ${ }^{205}$

$\ldots$ at the bottom line there are two paramount factors. First, that the welfare and interests of these children, in this particular family situation, must come first. Second, that any generalisation or theoretical assumptions about the value of family connections must, in the end, give way to the pragmatic reality that it is the welfare of these children with these particular parents that must be addressed.

This is comparable with the explicit wording of s 4(2) of the Care of Children Act.

Section 13 may be summarised as including: ${ }^{206}$

... principles that the rights of children be upheld and their welfare promoted. It is the right of a child to have a relationship with a parent notwithstanding that they may not live with that parent as long as the exercise of those rights are balanced with matters of protection.

The child should experience a family life which includes ongoing support and stable relationships with the person who cares for the child. Where the White Paper suggests that applicants have to show a change in circumstances before challenging a court order, ${ }^{207}$ this is a further step to secure the placement, to give a chance to develop a feeling of belonging to experience a family-like life.

(d) The views of the child

One of the key principles mentioned above is the right to participate. It contributes to the definition of the child's welfare and best interests and simultaneously restricts its

Re B (children) [1992] NZFLR 726 at 757.

At 757.

At 758 .

Ev G [parenting orders] 2008 NZFLR 337 at [44].

Paula Bennett, Ministry of Social Development "The White Paper for Vulnerable Children" (Wellington, 2012) volume II at 125. Clause 27 of the Family Court Proceedings Reform Bill 2012 restricts proceedings under the Care of Children Act (inserting s 139A): Proceedings under ss 46D (disputes between guardians), 48 (parenting order) or 56 (variation or discharge of parenting orders) may not be commenced without the leave of the court if that proceeding (a)is substantially similar to a proceeding previously filed in a Family Court by any person and (b) is to be commenced less than 2 years after final judgment was given in the previous proceeding. Clause 80 amends the Children, Young Persons, and Their Families Act 1989. Sections 206A and 206B shall be inserted which also require leave of the court. 
interpretation. According to s 6 of the Care of Children Act "a child must be given reasonable opportunities to express views on matters affecting the child: and any views the child express ... must be taken into account" in proceedings involving the guardianship of or the role of providing day-to-day care for a child. ${ }^{208}$ The Care of Children Act requires a reasonable opportunity to express views, which also must be taken into account. According to s 4(6), taking the child's view into account is not limited by the principle that decisions should be made and implemented in an appropriate time frame or by any of the principles in s 5 that are relevant to the child's welfare in his or her particular circumstances. At least taking the child's views into account is given emphasis. The importance of an appropriate consideration of the views of the child is examined above. ${ }^{209}$ However, where the child's voice is not considered it is likely that judges or, for example, Child, Family and Youth will interpret the welfare in a wrong way from a parent's/adult's point of view. Furthermore, the welfare principle could be used to overrule the wishes and views of the child.

Section 5(d) of the Children, Young Persons, and Their Families Act refers to the wishes of the child stating that any court must be guided by: ${ }^{210}$

... the principle that consideration should be given to the wishes of the child or young person, so far as those wishes can reasonably be ascertained, and that those wishes should be given such weight as is appropriate in the circumstances, having regard to the age, maturity, and culture of the child or young person.

The wishes of the child or young person do not have to be followed. Section 5(d) only requires a reasonable ascertainment. Furthermore, because of the mandatory consideration of the age, maturity and culture of the child the importance of the wishes is weakened. Coyle sees there an inconsistency. ${ }^{211}$

Moreover, there is a similar limitation of the relevance of the views under the Care of Children Act: ${ }^{212}$

While s 6(2)(b) of the Act requires any wishes of the child to be taken into account, that does not require a Judge to give effect to them, particularly if the child is of an age where he or she is immature and has no real understanding of longer term consequences of the wishes expressed.

A general disregard of the views/wishes of the child because of an age scheme does not meet the requirements set by the welfare principle as the paramount consideration. Here, too, the

\footnotetext{
$208 \quad$ Care of Children Act 2004, s 6.

209 See above chapter IV C at 14.

210 Children, Young Persons, and Their Families Act 1989, s 5.

211 Stephen Coyle "Permanency policy: children in care" (2008) 6 NZFLJ 45 at 47.

$212 \quad P J K W v$ DAR [Guardianship] [2006] NZFLR 946 at [67].
} 
particular child and his or her personal skills need to be considered. Otherwise, the paramount principle would merely be determined by others, which may weaken the acceptance of the decision by the child on the one hand and is, on the other hand, contrary to human dignity, because humans are self-determining beings. Therefore, at least, s 5 of the Children, Young Persons, and Their Families Act is too weak to give enough weight to the "participation" right of the child. ${ }^{213}$

\section{(e) Summary}

The New Zealand statutes declare welfare as the first and paramount consideration. The Care of Children Act contains several principles to clarify what is meant by welfare of the child. Due to the fact that both statutes deal with the same child at different stages in time and uniformity of law the principles in the Care of Children Act can be used to clarify the child's welfare even though the case is dealt with under the Children, Young Persons, and Their Families Act. In addition, the provisions of the Children, Young Persons, and Their Families Act should not be ignored only because orders under the Care of Children Act are made. To support this approach it may be necessary to amend the two Acts so both take the relevant principles into account.

The principles contained in s 5 of the Care of Children Act, except the child's safety, have equal weight: only welfare itself is paramount. Lastly, part of this is the consideration of the views and wishes of the child. ${ }^{214}$ In the end, the question of what meets the specific child's needs, not the parent's or the needs of another child, has to be answered. ${ }^{215}$

The previous examination shows that the emphasis is on the child. The provisions try to focus on the experience of a family life and continuing relationships, where the child is a full member, can develop an own personality and is safe. However, some of the provisions dealing with guardianship seem not to correspondent entirely with these principles. ${ }^{216}$

\section{Guardianship}

After the definition of guiding principles, it is necessary to examine the legal provisions the statutes contain that enable parents or another person to act on behalf of or care for a child: guardianship. Birth parents are the natural parents of a child. Any other person can become a court-appointed guardian conferring rights and responsibilities.

\footnotetext{
213 See the recommendations regarding participation below in chapter VII F at 96. The Family Court Proceedings Reform Bill 2012 undermines child participation by restricting the appointment of lawyer for the child.

214 See below chapter VII F at 96 regarding possible changes.

215 CEMSD v M FC Dunedin FAM-2001-012-148, 15 April 2005 at [31].

216 See the following examination.
} 
(a) Guardianship defined and the exercise of guardianship

(i) Meaning of guardianship

The Care of Children Act deals in s 15 with guardianship: ${ }^{217}$

For the purposes of this Act, guardianship of a child means having (and therefore a guardian of the child has), in relation to the child, (a) all duties, powers, rights, and responsibilities that a parent of the child has in relation to the upbringing of the child: (b) every duty, power, right, and responsibility that is vested in the guardian of a child by any enactment.

The first part of the definition seems to be circular: "Parental powers for the most part arise from the parents' status as their child's guardian." ${ }^{218}$ Therefore it might be necessary to have a look at the "natural" role of parents and their related obligations. Guardianship means that there is an individual, who is responsible for the child's upbringing, who has the responsibility to nurture and care. ${ }^{219}$ Furthermore, of course, this person has also the power to make decisions on behalf of the child, as long as the child is not able to manage his or her own affairs independently. ${ }^{220}$

The question may be why birth parents are given the statutory guardianship rights and what significance their rights have in this regard. In Neho $v$ Duncan Judge Inglis QC in referring to Jeffries $\mathrm{J}$ in $E \vee M^{221}$, cited with approval in Director-General of Social Welfare $v L{ }^{222}$ declares that: $:^{223}$

... three plain reasons can be identified. In the first place there has to be someone with full legal capacity to make decisions regarding the child which the child, who has no legal capacity, cannot make himself. Secondly, by providing the parents with an entrenched status, the family unit of parents and child is protected from gratuitous or unjustified outside interference. Thirdly, ... the fact that the parents have legal guardianship rights in respect of the child fastens on them the responsibility for nurturing the child to the stage where the child becomes independent of the parent: to provide shelter, clothing, food, together with love and affection and, in preparation for independence, education in its broadest sense, all demanding close and attentive physical and emotional involvement.

$217 \quad$ Care of Children Act, s 15.

218 Brookers Family Law - Child Law (online looseleaf ed, Brookers) at [CC15.02].

$219 \quad$ At [CC15.04].

See Gillick v West Norfolk and Wisbech Area Health Authority [1986] 1 AC 112, [1985] 3 All ER 402 at 421; Brookers Family Law - Child Law (online looseleaf ed, Brookers) at [CC15.04].

$221 \quad E v M$ HC Wellington M 316/79, 13 September 1979.

$222 \quad$ Director-General of Social Welfare v L [1989] 2 NZLR 314.

$223 \quad$ Neho $v$ Duncan [1994] NZFLR 157 at 160. 
Besides this general approach, s 15(b) of the Care of Children Act points to other current statutes and, according to some examples, parents are responsible for the enrolment and regular attendance at school, ${ }^{224}$ for providing the necessities of life and adequate health care $^{225}$ and the protection of the child. ${ }^{226}$ Further on, they have to give consent to a marriage until the child turns $18 .{ }^{227}$ Consent of a guardian has to be obtained for entering a civil union as long as the child is under 18 years ${ }^{228}$ as well as for entering a de facto relationship. ${ }^{229}$

In addition, s 16(1) provides regulations for the exercise of the guardianship stating that: ${ }^{230}$

The duties, powers, rights, and responsibilities of a guardian of a child include (without limitation) the guardian's (a) having the role of providing day-to-day care for the child: and (b) contributing to the child's intellectual, emotional, physical, social, cultural, and other personal development; and (c) determining for or with the child, or helping the child to determine, questions about important matters affecting the child.

According to s 8, "day-to-day care includes care that is provided only for one or more specified days or parts of days". ${ }^{231}$ Conversely, this does not mean that longer-lasting care is not to be subsumed under this legal term.

Interpreting a change to the concept of childhood, providing the child with rights and considering the child as an independent personality, the Care of Children Act no longer uses terms such as "possession" or "control". ${ }^{232}$ Rather, the guardian has the obligation to contribute to the child's development. ${ }^{233}$ According to Baragwanath $\mathrm{J}$ the Care of Children Act puts a greater emphasis on the rights of the child. A shift in policy can be recognised "from an emphasis on parental rights to exclusive focus on the rights of the child, the parents' position being assessed nowadays in terms not of rights but of responsibilities." 234 Examining a distinction between duties and rights Judge Inglis QC stated that: ${ }^{235}$

... the focus must be, not so much on the parental right in the abstract, but rather on how or whether that right is exercised and the impact of such exercise or non-exercise on the child. Thus, in specific cases, the focus must be directed on the parental duties and obligations which are the unavoidable correlatives of the parental rights. And it is only

\footnotetext{
$224 \quad$ Education Act 1989, ss 20(1), 24(1) and 29(1).

Crimes Act 1961, s 152.

Crimes Act 1961, ss 152, 154; Summary Offences Act 1981, s 10B.

Marriage Act 1955, s 18.

Civil Union Act 2004, s 19.

Care of Children Act 2004, s 46A.

Section 16(1).

Section 8.

See Guardianship Act 1968, s 3.

See Brookers Family Law - Child Law (online looseleaf ed, Brookers) at [CC16.04].

Auckland District Health Board v AZ and BZ HC Auckland CIV 2007-404-2260, 27 April 2007 at [20]. Neho $v$ Duncan [1994] NZFLR 157 at 160-161.
} 
one analytical step from that to perceive parental duties and obligations in terms of the correlative right of the child to expect that those parental duties and obligations will be carried out and performed for the benefit and the welfare of the child.

(ii) Guardianship as a dwindling right

In the High Court decision Hawthorne $v$ Cox Heath $\mathrm{J}$ had to deal inter alia with the question of whether an alleged behaviour of a mother can justify a guardianship order in favour of the court. ${ }^{236}$ The first respondent was the lawyer for the 16-year-old minor and applied for a guardianship order which was made by the Family Court. The mother successfully appealed against this order, though the Judge said that "inappropriate controlling conduct is inconsistent with the obligations and responsibilities of a guardian." 237 The guardians of the 16-year-old girl "ought only to exercise advisory responsibilities" and contrary actions to those principles "may well be grounds to remove the person concerned as a guardian." 238

Declaring that the concept of guardianship is a cooperative process and as such requires "collaboration between guardian and child (on the one hand) and between guardians themselves (on the other)" 239 and that duties, powers, rights and responsibilities are the predominant factors determining the role of a guardian pursuant to $s$ 16(1) of the Care of Children Act, ${ }^{240}$ Heath J identified s $16(1)$ underlying principles in the following way: ${ }^{241}$

(1) The younger the child, the more likely it is that decisions about important matters will need to be made by his or her guardian. (2) As the child gets older and becomes more mature, the guardianship role changes to that of an advisor or a counsellor, endeavouring to assist the child to make good decisions.

Furthermore, Heath $\mathrm{J}$ declared that the Act is consistent with the Gillick approach: the rights of parents to make decisions of behalf of their child decrease as the child grows older and reaches "sufficient intelligence and understanding to make up his own mind" 242 or in his words: "namely that a parent's interest in the development of his or her child does not amount to a 'right' but is more accurately described as 'a responsibility or duty", which is reflected in $\mathrm{s} 16$ itself. ${ }^{243}$

In Gillick $v$ West Norfolk and Wisbech Area Health Authority and another the House of Lords had to deal with the question whether or not an under 16-year-old girl could be given

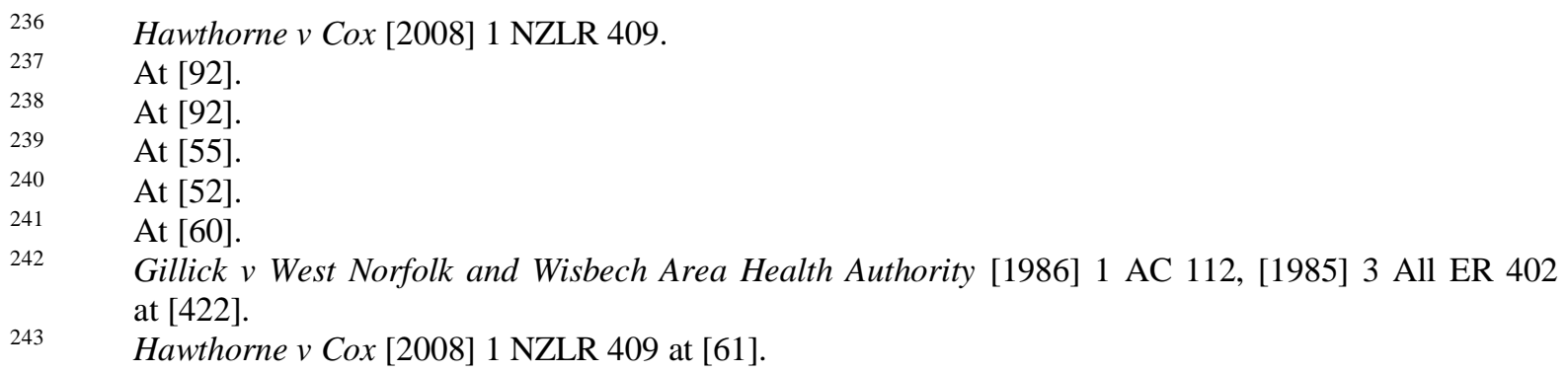


treatment on contraception without the knowledge or permission of the parents. ${ }^{244}$ Lord Scarman concluded "that parental rights are derived from parental duty and exist only so long as they are needed for the protection of the person and property of the child." 245 Furthermore, as the child's welfare is the paramount principle, it: ${ }^{246}$

... limits and governs the exercise of parental rights of custody, care and control. It is a principle perfectly consistent with the law's recognition of the parent as the natural guardian of the child; but it is also a warning that parental right must be exercised in accordance with the welfare principle and can be challenged, even overridden, if it be not.

The parental right is not an absolute right. Over time it is dwindling and "ends with little more than advice." ${ }^{247}$ Citing this, Lord Scarman declared: ${ }^{248}$

The principle is that parental right or power of control of the person and property of his child exists primarily to enable the parent to discharge his duty of maintenance, protection and education until he reaches such an age as to be able to look after himself and make his own decisions.

In Director-General of Social Welfare $v L$ the Court of Appeal dealt with the question of whether or not a mother's consent to adoption should be dispensed and what role the child's welfare and best interests plays in this regard. Hardie Boys $\mathbf{J}$ stated that the: 249

... rights of the natural parent arise from status and from the natural family relationship. But they are not absolute rights. They depend on the parent exercising the responsibilities of parenthood.

This shows that the emphasis is on the child and parental rights serve only to support the development of the child. These are not "rights" that parents can enforce against their child. Parents have duties and responsibilities and they are entitled to fulfil these to the benefit of the child's welfare. Therefore, it can be concluded that parental "rights" do not exist, if they are pursued to the detriment of the child. Therefore, any action, which harms the child's welfare even in an insignificant way, can never be justified.

(iii) Further provisions regarding the exercise of guardianship rights

Section 16(3) of the Care of Children Act declares that: ${ }^{250}$

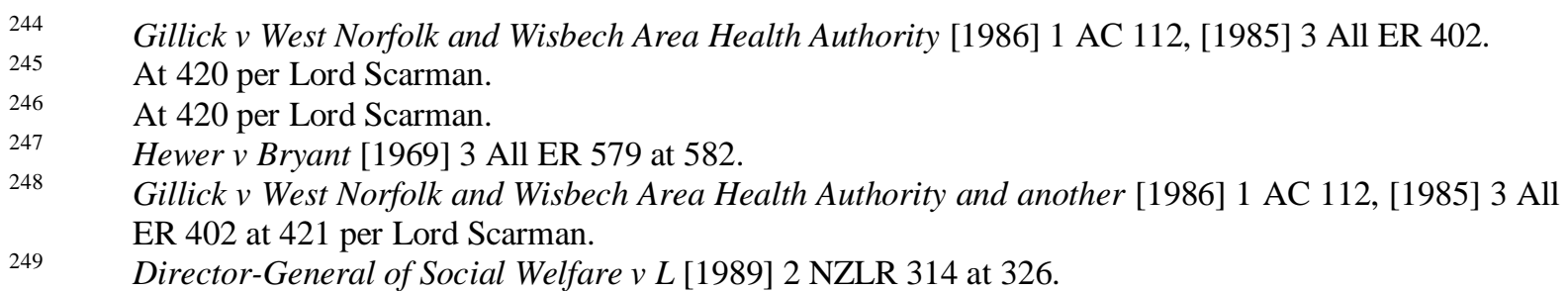


A guardian of a child may exercise (or continue exercise) the duties, powers, rights, and responsibilities of a guardian in relation to the child, whether or not the child lives with the guardian, unless a court order provides otherwise.

Firstly, s 16(3) does not provide a power to remove the duties, powers, rights and responsibilities of a guardian. ${ }^{251}$ This section only declares that a court order may have this result, whether under this Act or another. ${ }^{252}$ Secondly, s 16(3) recognises that "a separation does not in itself mean that the ... joint guardianship responsibilities ... need to be changed." 253 Especially in cases where the child lives with foster parents, who are additional guardians, this plays a role. Pursuant to s 16(5):

$\ldots$ in exercising ... the duties, powers, rights, and responsibilities of a guardian in relation to a child, a guardian of the child must act jointly (in particular, by consulting wherever practicable with the aim of securing agreement) with any other guardians of the child.

The idea is clear and self-evident at first blush. The parents of a child should act together and in "normal" cases this does not have to be declared. However, this mandatory codification may raise problems where parents separate and even more where a third party becomes a guardian of the child. ${ }^{254}$

Another problem relating to the compulsory collaboration of guardians results from s 16(6) declaring that this "does not apply to the exclusive responsibility for the child's day-to-day living arrangements of a guardian exercising the role of providing day-to-day care." When consultation is necessary remains unclear. ${ }^{255}$

(iv) Guardianship under the Children, Young Persons, and Their Families Act

According to s 110, the court can make guardianship orders in favour of the chief executive of the Ministry of Social Development or other persons as, for example, new caregivers, if the child is in need of care and protection. ${ }^{256}$ Pursuant to s 2(1) "guardianship has the meaning as given to it by section 15 of the Care of Children Act". ${ }^{257}$ Further discussion of the concept is therefore unnecessary.

\footnotetext{
$250 \quad$ Care of Children Act 2004. S 16(3).

$251 \quad J S v C R$ HC Auckland CIV-2011-404-002711, 20 September 2011 at [17].

$252 \quad$ At [17].

253 Rivers $v$ Carian FC Palmerston North FP054/327/97, 23 August 2002 as cited in Brookers Family Law

- Child Law (online looseleaf ed, Brookers) at [CC16.13].

$254 \quad$ See below VI A at 79.

255 Family Law Service - Guardianship (online looseleaf ed, LexisNexis) at [6.201].

$256 \quad$ See also below chapter V A 3 (b) at 47.

257 Children, Young Persons, and Their Families Act 1989, s 2(1).
} 


\section{(v) Summary}

Guardianship as a legal concept confers rights and responsibilities to bring up a child. Caused by a "natural order" parents have these rights. ${ }^{258}$ In regard to the child the parental right is not a right. It is dwindling and exists only as long as it is exercised for the benefit of the child. As parents "normally" do, guardians have to work jointly together.

\section{(b) Appointment as guardian}

The birth parents are usually the natural guardians of a child. ${ }^{259}$ In addition to this, on an application by any person or on its own initiative, on making an order removing a guardian under s 29 of the Care of Children Act, a court may appoint a person as guardian of a child. ${ }^{260}$ There is no restriction on who may apply to be appointed nor an age restriction. One main reason for an application is to formalise the actual responsibilities when another person instead of the natural guardians cares for the child. ${ }^{261}$ Furthermore, the actual caregiver will have a say in decisions affecting the child. ${ }^{262}$ In particular, foster parents "may seek greater security and recognition of their role". ${ }^{263}$ The court may appoint the person either in addition or as a sole guardian. ${ }^{264}$ "In addition to any other guardian" means that a child can have more than two guardians. In $S v C$ the grandparents were appointed as additional guardians to have a protective role in the child's life because the mother was concerned that there would be difficulties with the father in the future. ${ }^{265}$ In Crother $v$ Green Judge von Dadelszen said that "it would be unrealistic for the child not to have as a guardian the person who was entrusted with the custody." 266 Hence, the grandmother who already had custody was appointed. The guardian can be appointed either for a specific purpose or generally, ${ }^{267}$ and either for a specific period or not. ${ }^{268}$

The child's welfare has to be paramount. ${ }^{269}$ As stated above, s 5 of the Care of Children Act contains principles that have to be considered in determining the welfare of the specific child.

\footnotetext{
258 An examination whether the parental right is a natural right or a legal status awarded to parents by the state is beyond the scope of this dissertation.

259 However, some fathers will not be guardians, see Care of Children Act 2004, ss 17ff.

260 Care of Children Act, s 27(1).

261 Brookers Family Law - Child Law (online looseleaf ed, Brookers) at [CC27.02].

262 At [CC27.02].

263 At [CC27.02]

264 Care of Children Act, s 27(1).

$265 S v C$ FC Marton FP 034028 94, 28 April 1995 as cited in Family Law Service - Guardianship (online looseleaf ed, LexisNexis) at [6.204].

266 Crowther v Green FC Hastings FP020/113/96, 24 June 1998 as cited in Brookers Family Law - Child Law (online looseleaf ed, Brookers) at [CC27.02].

Care of Children Act, s 27(2)(a).

Section 27(2)(b).

See Care of Children Act, s 4(1).
} 
Because of the appointment of a guardian several principles may be affected. ${ }^{270}$ However, to serve the welfare of a child, generally, the person who is actually caring should be appointed as guardian. ${ }^{271}$ The appointment grants the person a recognised legal status and supports the person in fulfilling the parental role. Therefore, it is appropriate.

Under the Children, Young Persons, and Their Families Act a court can appoint any other person to be a guardian where it makes a declaration pursuant s 67 that a child is in need of care and protection. ${ }^{272}$ According to $\mathrm{s} 14$, a child is in need of care or protection if the child is being harmed, ill-treated, abused or seriously deprived, ${ }^{273}$ the child's well-being is being impaired or neglect, and that impairment or neglect is serious and avoidable, ${ }^{274}$ serious differences between the child and the parents or guardians exist to such an extent that the physical or mental or emotional well-being of the child is seriously impaired, ${ }^{275}$ the parents are unwilling or unable to care for the child, ${ }^{276}$ the parents have abandoned the child ${ }^{277}$ or serious differences exist between a parent or guardian and any other parent or guardian to such an extent, that the physical or mental or emotional well-being of the child is being seriously impaired. ${ }^{278}$ The court may appoint a person as sole guardian of the child ${ }^{279}$ or in addition to any other guardian, ${ }^{280}$ whereupon the consent of the person is necessary. ${ }^{281}$ The Act makes no provisions to appoint a guardian only for certain matters, in contrast to s 27(2)(a) of the Care of Children Act. However, in Director-General of Social Welfare $v R$ it was declared that an additional guardian can be appointed "both 'generally' and for [a] "particular purpose"" under ss $110,114 .^{282}$ Section 112 gives the court the power to appoint the chief executive as a guardian for a particular purpose. ${ }^{283}$ The question is why does legislation not provide this possibility for any other person. ${ }^{284}$

\footnotetext{
270 The principles contained in s 5(a): primary responsibility of the child's parents; s 5(b): continuity in the care arrangements and continuing relationship with both parents; s 5(d): relationship between child and family members should be preserved and strengthened; and s 5(e) protecting the child's safety. See Brookers Family Law - Child Law (online looseleaf ed, Brookers) at [CC27.04].

272 Children, Young Persons, and Their Families Act, s 110(1); according to s 70, no application for a declaration may be made unless a family group conference has been held in several circumstances. The family group conference is not part of this dissertation due to the word limit. answer to the question whether or not permanent caregivers should become sole guardians.
} 
A person appointed as a sole guardian under the Children, Young Persons, and Their Families Act has the same rights as set out in s 27 of the Care of Children Act. ${ }^{285}$

Whether appointed under the Children, Young Persons, and Their Families Act or under the Care of Children Act the previous guardians remain guardians unless their guardianship rights are removed under the Care of Children Act. ${ }^{286}$ Doogue $\mathrm{J}$ said that sole guardianship under the Children, Young Persons, and Their Families Act cannot be compared with the removal of a parent as guardian under the Care of Children Act. ${ }^{287}$ Effectively, the guardianship rights are suspended. ${ }^{288}$ According to s 114(2) of the Children, Young Persons, and Their Families Act, where a person is appointed as sole guardian the rights, responsibilities and duties of any other guardians are suspended and have no effect. However, the person remains a guardian. The White Paper intends to limit or reduce guardianship rights. The court will "direct which guardianship powers [should] reside exclusively with the caregivers." 289

\section{(c) Removing a parent as guardian}

An additional guardian has to work together with the birth parents. This can lead to several problems. One way of avoiding these problems is the termination of parental guardianship rights.

\section{(i) Existing provisions}

The guardianship of parents ends normally when the child turns 18, lives with another person in a de facto relationship, marries or enters a civil union. ${ }^{290}$ However, s 29(1)(a) contains regulations to make a court order to deprive a parent of the guardianship of his or her child. In addition, s 29(3) encloses in this respect the various cases: ${ }^{291}$

An order under subsection (1)(a) (that is, an order depriving a parent of the guardianship of his or her child) must not be made unless the court is satisfied (a) that the parent is unwilling to perform or exercise the duties, powers, rights, and responsibilities of a guardian, or that the parent is for some grave reason unfit to be a guardian of the child; and that the order will serve the welfare and best interests of the child. Family Law Service - Children, Young Persons, and Their Families (online looseleaf ed, LexisNexis) at [6.578].

$286 \quad A v D-G S W[1995]$ NZFLR 241 at 245-246.

287 Director-General of Social Welfare v B HC Palmerston North M 42/97, 18 August 1997 at 15.

$288 \quad A v D-G S W[1995]$ NZFLR 241 at 246.

289 Paula Bennett, Ministry of Social Development "The White Paper for Vulnerable Children" (Wellington, 2012) volume II at 125.

290 Care of Children Act, s 28(1)(a).

291 Section 29(3) (emphasis added).
} 
The first reason to remove a parent as guardian is his or her unwillingness to perform or exercise this role. ${ }^{292}$ "'Unwilling' ... results from an act of will rather than force of circumstances." 293 Furthermore, if a parent creates circumstances which prevent the fulfilment of guardianship duties and responsibilities this cannot be labelled as "force majeure" and the court could remove him or her as guardian as well. ${ }^{294}$ "Unwilling" may be not applicable when the parent cannot fulfil the parental role. ${ }^{295}$

Second, to remove a parent as guardian a grave reason is needed. "Grave" in this context means "really serious". ${ }^{296}$ Because of this grave reason the parent must be "unfit" to perform the role as a guardian of the child. A parent is "unfit" when his or her behaviour "constitutes a risk to the child's physical or psychological safety or wellbeing." 297 As the removal of a parent "should not be seen as a punishment for bad behaviour" the parent's status as guardian must be harmful to the child and, therefore, minor deficiencies may be not sufficient. ${ }^{298}$ Serious reasons may be because of sexual abuse of the child or siblings or criminal convictions which put the parent in a situation of being unable to perform the role of a guardian because of the length of imprisonment or the nature of the conviction. Violence towards the other parent of the child or physical abuse of the child can be reasons to remove a parent as well as serious mental illness.

In Pita $v$ Putahi the father was removed as guardian because he murdered the mother of the child. ${ }^{299}$ According to Judge Inglis QC, he "disqualified himself by his own actions from any expectations that he might have any influences over [the child's] upbringing in the foreseeable future. ${ }^{, 300}$ Further on Judge Inglis QC stated:

There is no reason in [the child's] welfare, why [the other guardians of the child] should be required to consult with him on any guardianship issues, or that he should have the power to dispute any guardianship decisions they may make.

In $N v C$ - $D$ Judge Murfitt also dealt with the removal of a parent as guardian. The father seriously assaulted his 15 -days-old son sexually. ${ }^{301}$ The extremely serious assault in this case demonstrated "a fundamental repudiation of the responsibilities of a guardian to protect and nurture a child." 302

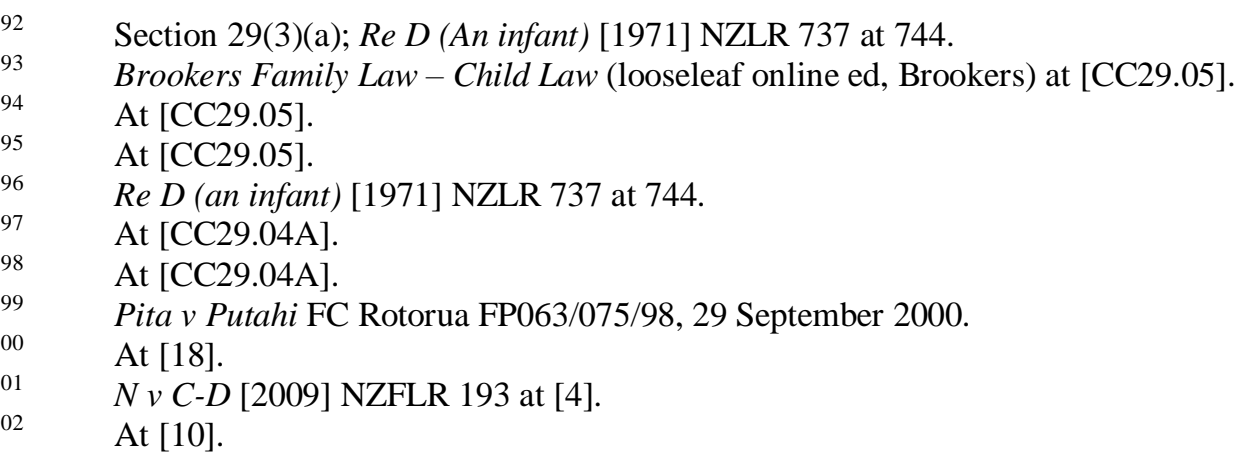


Where a parent is unwilling to meet the responsibilities of a guardian or unfit because of a grave reason the court can only remove guardianship if this serves the child's welfare and best interests. ${ }^{303}$ "The welfare and best interests principle emphasis continuity and strengthening of the relationship of the child and parent unless the child's safety is at risk." "304 The removal of a parent as guardian is very rare. ${ }^{305}$ It is seen as a further step to deprive a parent of guardianship, even if he or she is unfit. ${ }^{306}$ Courts may refrain if there is a strong bonding between the child and the parent and the removal of the guardianship could detrimentally affect the relationship and the child's welfare. Lastly, "the child must be given reasonable opportunities to express views on matters affecting the child" and these views have to be considered. ${ }^{307}$

\section{(ii) Application}

Only an eligible person is able to make an application for the purpose of removal: ${ }^{308}$

[Eligible] person, in relation to a child, means any of the following persons: (a) a parent of the child: (b) a guardian of the child: (c) a grandparent or aunt or uncle of the child: (d) a sibling (including half-sibling) of the child: (e) a spouse or partner of a parent of the child: (f) any other person granted leave to apply be the Court.

The legislation does not list the child as an eligible person. Rather, the child could apply for an order to deprive a parent of the guardianship as "any other person granted leave to apply by the Court". Especially considering that siblings are eligible persons pursuant to s 29(2)(d) irrespective of their age or maturity this provision seems to be inconsistent. Child, Youth and Family comes under the definition of "eligible person" under s 29(2)(f) as well as actual caregivers.

\section{(iii) Effect of removal}

To deprive a parent of his or her guardianship rights is the most dramatic measure that generally should be taken only in "exceptional circumstances". ${ }^{309}$ The status of the guardian is revoked. There is no provision in the statute to reinstate a natural guardian once the rights have been removed. "Presumably though, such a parent could come back as a courtappointed guardian." 310 In contrast, placing the child under the guardianship of the court does not extinguish the rights of a guardian. Rather they are suspended with the possibility to

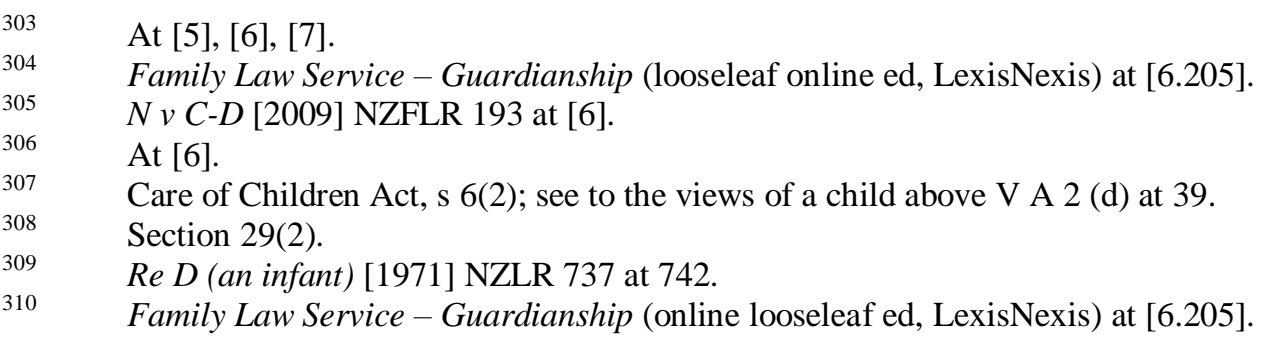


obtain them back. ${ }^{311}$ Otherwise the child would have no guardian at all when the guardianship of the court ends and "it is not easy to accept an interpretation which will have that result." 312 If the order granting the court guardianship is repealed the natural guardians are left and resume their role. ${ }^{313}$ It is stated that this approach is nevertheless "consistent with the grounds on which it can be made, being limited to parents who are either unwilling or unfit to be guardians." 314 An even less invasive possibility is the appointment of additional guardians. Again, birth parents as guardians would share their role and responsibility with a third party. ${ }^{315}$

\section{(iv) Criticism}

Albeit criticism seems justified. First of all, the provision is inconsistent in itself: there is a big gap between "unwilling" and "grave reasons" when the latter only relates to really serious cases. Furthermore, harm to a child can be done at an earlier stage. Therefore, it might be necessary to intervene before a grave reason occurs. Children have rights and they have needs to be met. With the focus on the child's welfare there is an objective minimum, even though the welfare has to be determined individually for every child: as stated above in defining welfare, food, shelter, clothing, education should be provided. Where a parent fails to do so state intervention to protect the child is necessary. Of course, not in every case guardianship rights should be removed. Several steps to help the family to overcome the problems should be taken. However, bearing in mind that the child's welfare has to be paramount and the child's safety must be protected, furthermore, that the child should grow up in a harmonious family-like setting with the possibility to develop an individual personality to become a full member of the society, it is debatable whether the removal of a parent should happen at an earlier stage. Physical harm towards the child must be a reason to remove a parent as a guardian. ${ }^{316}$ Furthermore, "unwilling" should be interpreted in a broader sense. As research shows that neglect can lead to brain damage $\mathrm{e}^{317}$ and thus negatively affect the child's welfare, a neglectful parent has to be seen as "unwilling".

As stated above, the child's welfare is influenced by different issues. However, where the physical integrity is no longer protected, parents do not deserve to care for their child. Physical integrity is the minimum standard, if such a standard has to be determined.

\footnotetext{
$311 \quad$ Hawthorne v Cox [2008] 1 NZLR 409 at [81].

$312 \quad \operatorname{Re} T$ [1982] 2 NZLR 662 at 664.

313 At 664.

$314 \quad$ Hawthorne v Cox [2008] 1 NZLR 409 at [82].

315 See below V B 1 at 65.

316 Physical harm in this regard is seen as lasting physical damage, intentional injury.

317 Nicola Atwool "Permanency: what children need" (New Zealand Law Society Care and Protections Orders and CYFS Seminar, Wellington, 25 October 2012).
} 


\section{(v) Potential risks}

Another question may be whether the child has to be an actual victim or whether potential risk is sufficient, for example, where another child of the parents was abused or neglected. Again, the specific circumstances of the case have to be taken into account. Potential risk is a reason to look more closely and to monitor the relationship between parents and child. But potential risk itself, caused by past deeds towards other persons, may not be sufficient enough to remove guardianship rights. Especially if a long time has passed, the parents must be given the opportunity to change and to prove that they have changed.

The White Paper contains a proposal to introduce Child Abuse Prevention orders which focus on future risks rather than past behaviour. ${ }^{318}$ It does not include a suggestion to limit parental responsibilities where a placement places a future risk at the child.

\section{(vi) Proceeding}

Lastly, there should be no debate about the question of who should make such a decision. It is a serious step. Parents should be given the opportunity to be heard. They have to have procedural rights, have to have the chance to appeal and to challenge the decision until a certain point in time when circumstances have changed. This right must expire when the child lives in secure permanent placement and any disruption would be detrimental. In the end, the decision has to be made by an objective authority. Therefore, the decisions must be made by a judge within a process of law.

Finally, it is important to note that a grave reason or unwillingness is no prerequisite removing a guardian who is not a birth parent. Therefore, it is sufficient enough that the order will serve the child's welfare and best interests. ${ }^{319}$ Where non-birth parents have become psychological parents for the child this can be seen as inconsistently focusing on the child's welfare. Or with other words: Is the blood tie so strong that the child must accept more detriment?

\section{(vii) Summary}

It has to be kept in mind that the specific child has to be considered. Besides the more general minimum standard, specific reasons can occur that can be seen as sufficient reasons to remove a parent as guardian. To have the opportunity to care for a child should be seen as something special, not as onerously task.

\footnotetext{
318 Paula Bennett, Ministry of Social Development "The White Paper for Vulnerable Children" (Wellington, 2012) volume II at 138.

319 Care of Children Act, s 29(4).
} 
As shown, the removal of a parent as guardian is rare and happens only in exceptional cases. Where children can no longer live with their birth parents, often the chief executive becomes sole guardian ${ }^{320}$ and after discharging this order the new caregivers can be appointed additional guardians. This means that they have to work jointly together with the birth parents.

The White Paper talks about limiting parental guardianship rights. This is a less restrictive intervention than a removal. Unfortunately, it remains unclear whether birth parents can get legal responsibilities back. Probably not, because the new guardianship orders will be used to finalise the permanent Home for Life care arrangement. ${ }^{321}$ The remaining question is why limit or reduce the rights only where the child is placed in a Home for Life arrangement? It may be necessary to remove guardianship rights where a parent places at high risk a child who does not yet live in a permanent placement, even though a "grave reason" is not apparent. The question of whether parental rights should be removed has to be distinguished from the question of whether foster parents should be given sole guardianship.

\section{$4 \quad$ Parenting and custody orders}

In some cases foster parents refrain from appointment as additional guardian due to the obligation of joint co-operation. Instead the chief executive remains guardian. To secure the placement with the new caregivers in such a case parenting orders can be achieved: ${ }^{322}$

On an application made to it for the purpose by an eligible person, the Court may make a parenting order determining the time or times when specified persons have the role of providing day-to-day care for, or may have contact with, the child.

Section 47(1) of the Care of Children Act determines what eligible person means. Thus an application can be made by: ${ }^{323}$

(a) a parent of the child: (b) a guardian of the child: (c) a spouse or partner of a parent of the child: (d) any other person who is a member of the child's family, whānau, or other culturally recognised family group, and who is granted leave to apply by the court: (e) any other person granted leave to apply by the court.

The new caregivers are not specially mentioned in s 47 as eligible person. Hence, they only have the opportunity to apply for a parenting order if the court granted leave. Therefore, "the

\footnotetext{
320 Pursuant to s 110(1), (2); only the director of a child and family support services cannot be appointed as sole guardian, s 110(3).

321 Paula Bennett, Ministry of Social Development "The White Paper for Vulnerable Children" (Wellington, 2012) volume II at 124.

322 Care of Children Act 2004, s 48(1).

323 Section $47(1)$.
} 
applicants need to demonstrate an appropriate and sustainable interest in promoting the welfare of the child" and have to show "that there is an arguable issue." "324 However, in an arguable case that the order would be in the child's best interests the court should grant leave. $^{325}$

A parenting order includes two different issues: day-to-day care for and contact with the child. $^{326}$

\section{(a) Day-to-day care}

As mentioned, a parenting order applies to the day-to-day care. According to s 48(2) of the Care of Children Act: ${ }^{327}$

A parenting order determining that a person has the role of providing day-to-day care for the child may specify that the person has the role (a) at all times or at specified times: and (b) either alone or jointly with [one] or more other persons.

Parenting orders give the court the opportunity to form arrangements which suit the particular child in his or her special circumstances. Section 48(5) declares that "a parenting order may also be subject to any other terms or conditions ... the Court determines." This provision is broad. Possible conditions can affect health, education, holidays and religion regarding the child. ${ }^{328}$ Furthermore, they can affect the parents directly as a parent has to undertake a parenting programme, go to rehab and undergo regularly recurring drug tests or avoid contact of specified people having the child in care. ${ }^{329}$

In the most cases, foster parents will apply for a parenting order in their favour to secure the relationship with the child more and get some legal responsibility. Parenting orders in their favour can be conditional. This may be the case if the child, for example, is raised in another religion from the new caregiver or there were some difficulties in the relationship between the birth parents and the new caregivers (especially if the placement is a kinship placement).

Situations can be imagined in which birth parents apply for parenting orders in their favour even when the child has lived for a longer period with new caregivers, justified by the principle in $\mathrm{s} 5(\mathrm{~b})$ that birth parents should have the primary responsibility and furthermore

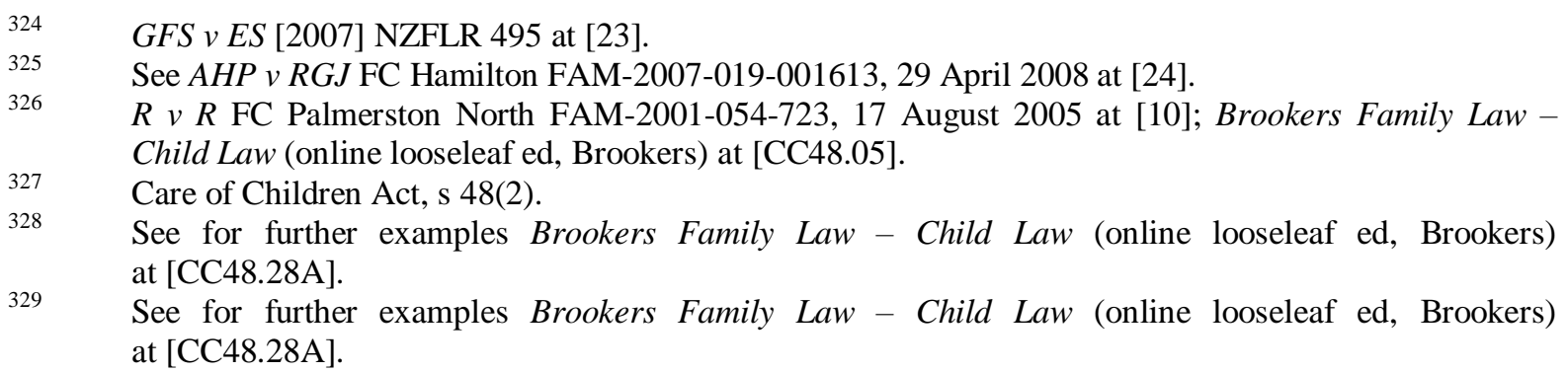


that the relationship between parents and child should be ongoing and supported. In several cases judges ordered shared day-to-day care between parents so the child has according to the principle set out in s 5(b) a continuing relationship with both parents. Nevertheless, if shared day-to-day care causes a risk to the child's welfare this is not an option. Gault J declared this in the case $B v V E:^{330}$

\begin{abstract}
Any arrangement by which the child spends substantial time with each parent has the potential for harm to the child arising from inconsistent activities, influences and living patterns. To reconcile these for the purpose of providing the child with stable and consistent support necessarily must involve substantial agreement and co-operation between the parents. These problems of course remain where children spend substantial periods of time with non-custodial parents exercising access rights. I think that the difficulties are likely to be less however when primary responsibility for the care of the child rests with one parent rather than with both.
\end{abstract}

Transferred to the situation of a permanent placement this means that the foster parent who actually cares for the child should be the only legally responsible person endowed with corresponding rights to avoid any risks for the child's welfare. Nevertheless, there is the possibility of a joint parenting order in the future, for example, where the child lives in a kinship placement. This can cause additional problems, when, for example, the grandmother has to work together with her own daughter for the benefit of her grandchild, even though she does not agree with the opinion of her own daughter. ${ }^{331}$

The legislation does not provide a presumption in favour of birth parents. As examined above, the child's welfare is the first and paramount consideration. This means that the welfare has to take priority over blood ties. ${ }^{332}$ Otherwise the child's welfare and best interests would be subordinated compared to the interests of birth parents: ${ }^{333}$

The biological tie does not give a natural parent a right to custody or access. The relevant right is the right of the child to have his or her welfare and interests treated as paramount.

If a child is subject to a guardianship or custody order under ss 78,101 or 110 of the Children, Young Persons, and Their Families Act, a parenting order cannot be made. ${ }^{334}$

According to s 101(1)(e) of the Children, Young Persons, and Their Families Act, a court may make an order placing the child in the custody of any other person. The person must

\footnotetext{
$330 \quad B v V E(1988) 5$ NZFLR 65 at 70.

$331 \quad$ See Marie Connolly “A kinship care literature review” (2003) 25 Social Work Now 24 at 28.

332 See A v Ministry of Social Development [Access] [2009] NZFLR 625 at [57].

333 At [57]

334 Children, Young Persons, and Their Families Act, s 120(1).
} 
consent to the order. ${ }^{335}$ These custody orders have the same effect a parenting order has, made under s 48(1) of the Care of Children Act. ${ }^{336}$ Pursuant to s 2 of the Children, Young Persons, and Their Families Act, custody means the right to possession and care of a child. ${ }^{337}$ Considering the child as a person with rights, there cannot be a "possession" of the child. In this regard, it is necessary to change the wording, perhaps comparable with the Care of Children Act.

A custody order suspends all rights, powers and duties of every other person having custody, ${ }^{338}$ so affecting every parenting order under the Care of Children Act. ${ }^{339}$ Judge Murfitt has held that a custody order may constitute a serious interference in the life of a citizen and should reflect this; therefore, it "should not be granted lightly." "340 Furthermore, in some cases a parenting order under the Care of Children Act is sufficient to respond to the special circumstances, so that a custody order is not required. ${ }^{341}$

\title{
(b) Contact
}

Parenting orders under the Care of Children Act can also define contact with the child. Therefore, a contact order is a form of a parenting order and not a seperate order itself; ${ }^{342}$ "a parenting order must be in place if a contact order is to be made." ${ }^{, 343}$ Section 48(3) declares:

\begin{abstract}
A parenting order determining that a person may have contact with the child may specify any of the following: (a) the nature of that contact (for example, whether it is direct (that is, face to face) contact or some form of indirect contact (for example, contact by way of letters, telephone calls, or email)): (b) the duration and timing of that contact: (c) any arrangements that are necessary or desirable to facilitate that contact.
\end{abstract}

Under the Children, Young Persons, and Their Families Act the court may make an order granting access ${ }^{344}$ to the child on an application made by any parent or any other person. ${ }^{345}$ This provision is wider than ss 47 and 48 of the Care of Children Act. Before making an

\footnotetext{
335 Children, Young Persons, and Their Families Act, s 101(3).

Section 104(1)(a).

Section 2 (emphasis added).

Section 104(1)(b).

Director-General of Social Welfare v R (1997) 16 FRNZ 357 at 374.

Child Youth and Family Service v S FC New Plymouth FAM-2005-043-784, 15 November 2006 at [67].

At [67].

Brookers Family Law - Child Law (online looseleaf ed, Brookers) at [CC48.37]. $R v R$ FC Palmerston North FAM-2001-054-723, 17 August 2005 at [11].

The Children, Young Persons, and Their Families Act uses the word "access". In the following the term "contact" will be used instead.

Children, Young Persons, and Their Families Act, s 121(2)(d) (emphasis added).
} 
order granting contact, there has to be a custody order or a guardianship order, ${ }^{346}$ and thus depends on the existence of a s 101 or s 110 order.

In the case of a permanent placement contact orders may be important for birth parents as the child does not live with them and is no longer in their personal daily care. Contact with birth parents may also be important for the child as it gives the child the chance to maintain relationship with the birth family. Furthermore, contact helps to preserve and strengthen the child's identity, which includes the child's origin. However, it should be kept in mind that contact with birth parents influences the relationship between the new caregivers and the child. Judge Inglis QC stated: ${ }^{347}$

... any such liberality of access must depend on the cooperation of [the child's] principal caregivers, and it would have to be said that it is demanding enough to ask the caregiver to cope with a disturbed child without also having to cope with access problems as well.

It is important to find the right balance. There is not only the question of whether or not a child should have contact with birth parents. The form of contact - face to face or telephone, email, Skype - as well as the frequency and the duration have to be determined. This can be done within a contact order. ${ }^{348}$

Moreover, the frequency and form of contact may depend on the duration of the placement: "If it is anticipated that a child will be returned to their parents, then frequency of contact will be greater than children who are permanently placed." ${ }^{349}$ Furthermore, the possibility of having contact also depends on the reason for the removal of the child. There is a difference whether the child was removed because of neglect, abuse or mental health problems. This has also to be taken into account. Where the child is placed in the custody of any person pursuant to $\mathrm{s} 101$ of the Children, Young Persons, and Their Families Act and a contact order has not been made, this person has the sole authority to determine contact issues. ${ }^{350}$

On the other hand, where parents do not want to have contact to their child, it may be detrimental for the child to force them to do so, even though contact would support defining the child's identity. At least, there is the question of whether or not contact can be enforced against unwilling parents.

\footnotetext{
346 See Children, Young Persons, and Their Families Act, s 121(2)(b) or (a).

347 Re Children FC Napier CYPF 041/002/89, 13 June 1990 at 4 as cited in Family Law Service Children, Young Persons, and Their Families (online looseleaf ed, LexisNexis) at [6.578].

348 See Care of Children Act, s 48; and Children, Young Persons, and Their Families Act, s 121(3).

349 Tracy Gunn "Review of practice relating to representing clients in proceedings under the Children, Young Persons, and Their Children Act 1989" in Nicola Atwool and Tracy Gunn (eds) Care and Protection Orders and CYFS (paper presented to New Zealand Law Society Care and Protection 
Contact to birth parents can have a detrimental effect for the placement because of negative comments about the new caregivers or because parents do not accept their new role and their limitation or they have a different style in care-giving during the access time. "Where there is no buffer between those caregivers and the family group, the placement is destabilised commonly through access arrangements." ${ }^{351}$ However, it is also said that access may sometimes disrupt the placement, but "that this is the burden that goes with the privilege and joy of primary care." ${ }^{352}$ It should be kept in mind that a permanent placement "should suffer the minimum disruption." 353

Especially in a case of a permanent placement, contact will not be granted to develop a relationship between child and birth parents. In Chief Executive of the Ministry of Social Development $v S K$ Judge Somerville analysed the attachment of the children and the purpose of contact as follows: ${ }^{354}$

Because none of the boys is demonstrating attachments to anyone other than the foster parents, none of them is experiencing a sense of loss which should be addressed by access. Instead, they simply need to have an understanding of who their parents are that is based on reality and is not idealised. This will give them a sense of what has happened in their lives and an appreciation of where they come from.

Finally, the child's wishes have to be considered. Where a child wishes not to have contact, it should be denied. ${ }^{355}$ Nevertheless, contact to birth parents and other family members, for example, siblings might be important for the child. Therefore, the child's views have to be taken into account and should be the first consideration.

However, the focus is on the child's welfare. Contact to birth parents might be suspended or limited or the form might be varied, where the child would suffer detrimental effects, even though contact would be in the child's long-term interests. ${ }^{356}$ On the other hand, it is stated that, although contact would have lightly disadvantageous impacts on the child short-term, it should be granted because of the beneficial long-term effects. ${ }^{357}$ To understand the child's own background and identity is important and this can be achieved by contact. ${ }^{358}$

\footnotetext{
$351 \quad E v$ G [parenting orders] 2008 NZFLR 337 at [31].

$352 \quad C E M S D$ v $M$ FC Dunedin FAM-2001-012-148, 15 April 2005 at 49.

$353 \quad$ A v Ministry of Social Development [Access] [2009] NZFLR 625 at [18].

$354 \quad$ Chief Executive of the Ministry of Social Development v SK FC Christchurch FAM-2006-009-4165, 19 September 2011 at [33].

$355 \quad$ See Director-General of Social Welfare v R (1997) 16 FRNZ 357 at 371.

$356 \quad W v D-G S W(1991) 7$ FRNZ 450.

357 Re the L children (Family Court, Papakura CYPF 055/15-20/94, 7 December 2001 as cited in Family Law Service - Children, Young Persons, and Their Families (online looseleaf ed, LexisNexis) at [6.578].

$358 \quad$ See $A v$ Ministry of Social Development [Access] [2009] NZFLR 625 at [57], where it is said that "this is a reason why access will be directed."
} 
In the end, there is no general solution that fits all. Children in permanent placements cannot be compared with children in care of foster parents for a shorter time. Whether or not contact should be granted and how has to be answered case-specific and the special circumstances a specific child has to deal with have to be taken into account. Even in a permanent placement it might be appropriate to have more frequent contact. On the other hand, contact with birth parents can lead to loyalty conflicts and more negative experiences. First of all, the child has to be in a secure and safe placement. ${ }^{359}$ Contact must not be able to undermine this. Only where contact has a beneficial effect should it be granted.

\section{$5 \quad$ Resolving disputes}

There are different approaches to resolve a day-to-day care or contact dispute after the separation of the parents of a child, if they are not able to find a solution by themselves. "The underlying assumption in this area of law is that parents know what is best for their children." ${ }^{360}$ Keeping this in mind, the opportunities start by a joint meeting between the parties and their lawyers and negotiation through their lawyers, counselling and conciliation, and if those do not work out, at last a court hearing. ${ }^{361}$

However, in cases involving a third party such as because of a permanent placement with foster parents, those informal techniques do not seem helpful, especially if the parties are at odds with each other or the birth parents cannot accept the new situation. Nevertheless, the Care of Children Act requires the foster parents to work together with the birth parents of the child. ${ }^{362}$ When the adults involved are not able to agree on a certain matter, any of them can request a counselling or apply to the court for its direction. ${ }^{363}$ In the latter case, the court may make any order that it thinks proper. ${ }^{364}$ Possible disputes are not restricted to important matters affecting the child as referred to in s 16(2). ${ }^{365}$ They range from disputes about education, to religion, health and place of residents, as well as "disputes over consultation and sharing information between guardians". 366

\footnotetext{
$359 \quad$ Nicola Atwool "Permanency: what children need" in Nicola Atwool and Tracy Gunn (eds) Care and Protection Orders and CYFS (paper presented to New Zealand Law Society Care and Protection Orders and CYFS Seminar, Wellington, 25 October 2012) at 36.

$360 \quad$ Family Law Service -Day-to-day care and contact (online looseleaf ed, LexisNexis) at [6.101].

361 See Family Law Service - Day-to-day care and contact (online looseleaf ed, LexisNexis) at [6.102] for further explanation.

362 Care of Children Act, s 16(5).

363 Section 44(1). Clause 8 of the Family Court Proceedings Reform Bill 2012 will repeal s 44. The new introduced s 46D will deal with disputes between guardians; see clause 9. According to s 46D(1) any of the guardians may apply to the court for its direction they are unable to agree on a matter concerning the exercise of their guardianship. The court may make any order relating to the matter that it thinks proper, new s 46D(4).

364 Care of Children Act, s 44(3); see also Family Court Proceedings Reform Bill 2012, clause 9.

365 Brookers Family Law - Child Law (online looseleaf ed, Brookers) at [CC44.08].

366 At [CC44.08].
} 
The application can only be made by a guardian. This means that foster parents cannot apply if they are not appointed as guardians of the child, parents cannot apply if the guardianship rights have been removed and a guardian cannot apply to seek the court's direction in a dispute with a non-guardian. Where foster parents only have a parenting order the court cannot resolve disputes under s 44 . They may have the possibility to apply to vary the parenting order. There are no provisions to enforce the decision of the court. One possibility is to place the child under the guardianship of the court and direct an agent to take steps to enforce the order. ${ }^{367}$

Instead of making a direction the court could also make a time-limited or purpose-limited order to solve the dispute and give guardianship rights to a third or fourth person, especially if there are no parenting orders in force. ${ }^{368}$ However, in cases of a permanent placement with a new caregiver, this solution might not be appropriate, dividing the responsibilities between too many people. Finally, if the court could deal with the dispute sufficient under s 44 , changing the parenting order is not necessary. ${ }^{369}$

Furthermore, the court cannot make an order under s 44 if there are guardianship or custody orders in force under the Children, Young Persons, and Their Families Act. Under the Children, Young Persons, and Their Families Act a guardian may also apply to the court for its direction and the court has the power to make such an order as it thinks fit. ${ }^{370}$ As well as under the Care of Children Act, only a guardian can apply.

Even though both statutes contain provision to resolve disputes between parents and guardians, an application for such a direction is a further step to be taken. The dispute may exist much longer and during this time it may have a detrimental influence on the child's welfare. Furthermore, it cannot be advantageous for the child to be the permanent centre of disputes. No matter how good the new foster parents may be, they cannot hide ongoing disputes. On the other hand, the child cannot develop a feeling of security and belonging, if the caregivers are not able to decide everyday questions, for example, extracurricular activities or special school trips, without consent of the birth parents. Therefore, the current provisions seem insufficient to support the child's welfare.

Besides the imprecise wording of the White Paper, the proposal to limit parental guardianship rights "by enabling the Family Court to direct which guardianship powers should reside exclusively with the caregivers" may be a step to prevent future disputes. ${ }^{371}$

\footnotetext{
367 Brookers Family Law - Child Law (online looseleaf ed, Brookers) at [CC44.29]. At [CC27.07].

See Wright $v$ Wright [1984] 1 NZLR 366 at 372.

Children, Young Persons, and Their Families Act, s 115.

Paula Bennett, Ministry of Social Development "The White Paper for Vulnerable Children" (Wellington, 2012) volume II at 125.
} 
Birth parents can challenge court orders like guardianship orders or parenting orders in favour of the new caregivers. Under the Care of Children Act, the court may vary or discharge a parenting order, ${ }^{372}$ any other order about the role of providing day-to-day care for, or about contact with, a child, ${ }^{373}$ an order about the upbringing of a child ${ }^{374}$ or an order vesting the guardianship in a person. ${ }^{375}$ The application can be made by an eligible person, so a person affected by the order or a person acting on behalf of the child. ${ }^{376}$

A person affected by the order is someone the order has a material effect on. ${ }^{377}$ A parent or a

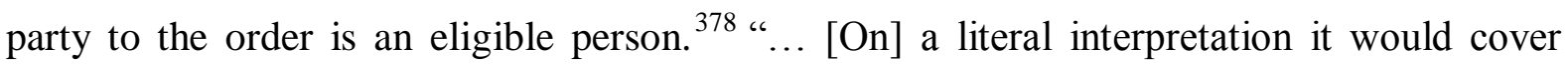
people ... who are not able [to] apply for a parenting order without prior leave of the court." ${ }^{379}$ The Care of Children Act acknowledges the role of the family, for example in s 5 and s 47 , so that the provision should be extended to the wider family or whānau. ${ }^{380}$

The applicant need not show a change in circumstances to file the application. Furthermore, the Care of Children Act does not contain any specific threshold that must be overcome before an application can be filed. Even though "the court may look closely at the reason for the application" and may dismiss the proceeding pursuant to s $140,{ }^{381}$ or "further litigation will not be permitted unless a welfare issue arises", ${ }^{382}$ it is in the end an intervention in the life of the child with the new caregivers that could be detrimental for the child. Indeed, s 141 declares that a person may commence a proceeding under the Act of any kind only with the leave of the court, if the court is satisfied that a person has persistently instituted vexatious proceedings under this Act and has given the person a reasonable opportunity to be heard. So once a court has dealt with a sufficient number of applications it can dismiss any further requests. However, before this "sufficient number" is reached, every application is a potential threat to the placement.

The Ministry of Justice published Family Court Review: a public consultation paper and asked whether access to the Family Court should be limited and whether changes are necessary due to the fact that ss 140,141 show limited use in practice because of the too high

Care of Children Act, s 56(1)(a).

Section 56(1)(b); which can be an order under s 44.

Section 56(1)(c).

Section 56(2).

Section 56(1) and (3).

$B v M$ [1997] 3 NZLR 202 at 205.

Brookers Family Law - Child Law (online looseleaf ed, Brookers) at [CC56.03].

At [CC56.03].

At [CC56.03].

At [CC56.05].

Family Law Service - Day-to-day care and contact (online looseleaf ed, LexisNexis) at [6.138]. 
thresholds. ${ }^{383}$ Some submissions "suggested greater powers were needed to limit vexatious and repeat claims." ${ }^{384}$ The ensuing Cabinet Paper provides that "a material change in circumstances" has to be shown before an application can be made. ${ }^{385}$ Furthermore, "any application may also be dismissed if its is contrary to the welfare and best interest of the child, if it purposes only minor changes, or is without merit." 386 Moreover, it is suggested that leave has to be obtained for "new proceedings ... where an order has been made within the previous two years". ${ }^{387}$ For the benefit of the child, these proposed changes are to embrace. In October 2012 the Family Court Proceedings Reform Bill 2012 was introduced. Clause 27 amends the Care of Children Act 2004 in inserting s 139A. According to s 139A leave has to be obtained. ${ }^{388}$ The same applies to the Children, Young Persons, and Their Families Act 1989 , amended by clause 80 which inserts the new ss 206A and 206B. ${ }^{389}$

An application to vary or discharge an order vesting the guardianship in a person applies to a court appointed guardian. ${ }^{390}$ Under such an application the court cannot suspend or remove guardianship rights; deprivation and suspension are dealt with under s $29 .{ }^{391}$ Guardianship rights may only be separated by a guardianship order for a limited time or limited purpose. ${ }^{392}$

According to s 56(4), any order under the Children, Young Persons, and Their Families Act cannot be varied or discharged because of an application under s 56 .

Under the Children, Young Persons, and Their Families Act the court has the power for a variation or discharge of inter alia any custody order made under s 101, any guardianship order made under s 110 and any order made under s 121 granting access to, or conferring rights in respect of, any child. ${ }^{393}$ Section 126 provides an extensive list of person who may apply for such a variation or discharge. An application can be filed, besides others, by the child in respect of whom the order was made, ${ }^{394}$ any parent or guardian of that child, ${ }^{395}$ any near relative of that child, ${ }^{396}$ any member of that child's whānau or family group, ${ }^{397}$ and, with

\footnotetext{
383 Ministry of Justice "Reviewing the Family Court: a public consultation paper" (Wellington, 20 September 2011) at 45-46.

384 Ministry of Justice "Summary of Submissions in response to Reviewing the Family Court: a public consultation paper" (Wellington, April 2012) at 27.

385 Minister of Justice "Family Court Review: Proposals to Reform" (2012) at [94].

386 At [94].

387 At $[95]$.

$388 \quad$ See also explanation above fn 207.

$389 \quad$ See also explanation above fn 207.

390 Brookers Family Law - Child Law (online looseleaf ed, Brookers) at [CC56.08].

$391 \quad$ CJJ v HJJ HC Auckland CIV-2011-404-2801, 28 September 2011 at [22].

392 Brookers Family Law - Child Law (online looseleaf ed, Brookers) at [CC56.09].

393 Children, Young Persons, and Their Families Act, s 125(1)(f), (g) and (h).

$394 \quad$ Section 126(a).

395 Section 126(b).

396 Section 126(d).

397 Section 126(e).
} 
the leave of the court, any other person. ${ }^{398}$ These provisions also do not contain a threshold to file an application. However, Judge van Dadelszen declared that the applicant has to demonstrate a change in the evidence and finding made at the time of the first order. ${ }^{399}$ Furthermore he said, that there may be cases where the court: ${ }^{400}$

... need to use the inherent power ... to prevent an abuse of its process and there needs to be a mechanism in place to prevent a repeat of this application unless the circumstances clearly justify it.

A court will only vary or discharge an order if it has "outlived [its] usefulness". ${ }^{401}$ Under the Children, Young Persons, and Their Families Act the court has to determine what the consequences will be if a protective order is withdrawn and whether the child is in need of care and protection. ${ }^{402}$

However, in the end it is again an intervention in the child's life and it can be disadvantageous for the placement of the child. It endangers the permanency and places the new caregivers in a "defence position". As already examined, a stressed situation for the caregivers can influence the child's welfare. Therefore, there should be a threshold to protect the new family environment against inappropriate interferences. The proposed changes may give more security to the placement.

\section{$7 \quad$ Summary}

One of the problems is that the Care of Children Act does not grant consistency for the affected child. The parenting orders as well as the guardianship orders can be challenged by the birth parents. Due to the contestability of the court order the relationship between the child and the new family could be destabilised or even more the placement could be overthrown. The same applies to the Children, Young Persons, and Their Families Act.

Court orders can be discharged or varied because of an application made by the birth parents, without having to meet certain requirements. This is disadvantageous for the security of the placement. Foster parents of children in permanent placements have to face the possibility of interference in their family environment. Parenting orders may not be strong enough to secure the placement. Furthermore, they seem not to be meant for long durations like years.

\footnotetext{
$398 \quad$ Section $126($ o).

$399 \quad S v D$-GSW FC Palmerston North CYPF (054) 7/90, 6 December 1990 at 4 as cited in Family Law Service - Children, Young Persons, and Their Families (online looseleaf ed, LexisNexis) at [6.580] n 12.

$400 \quad S \vee D-G S W[1991]$ NZFLR 89 at 91.

$401 \quad J G v$ Chief Executive of the Ministry of Social Development FC Rotorua FAM-1999-063-15, FAM2002-063-638, 22 May 2007 at [26]. At [26].
} 
However, this is the case with a permanent placement. With birth parents remaining guardians ${ }^{403}$ they have a say in the upbringing of the child. A parenting order cannot overrule guardianship rights. The exercise of these rights is only granted to someone else. This does not mean that the parents are cut off. A parenting order is not an appropriate legal mechanism for foster parents bringing up a child. The interferences they have to fear are too strong to have the feeling of security.

\section{B Foster Parents and Birth Parents}

Once a permanent placement is formalised the relationship between the child, the foster parents and the birth parents has to be determined. The persons involved have to find a way to balance the different issues, for example, the stabilising of the relationship between the new family and the child, on the one hand, and the remaining contact with the birth family on the other. The question that arises is which relationship should have priority and to what extent it should be privileged. Furthermore, the legal status, rights and responsibilities of everyone involved have to be determined.

\section{$1 \quad$ Foster parents as additional guardians}

To secure the placement the new caregivers can obtain guardianship orders to get an appropriate legal status to deal with the needs of the child and to integrate the child more into their foster family. According to s 27(1) and (2) of the Care of Children Act:

The court may appoint a person as a guardian of a child, either in addition to any other guardian or as sole guardian, either (a) on an application for the purpose by any person: or (b) on its own initiative, on making an order removing a guardian under section 29.

The court may appoint the person as a guardian of the child (a) either for a specific purpose or generally; and (b) either for a specific period or not.

Although the Care of Children Act provides the possibility of removing the birth parents of the child as guardians ${ }^{404}$ and appointing the new caregivers as sole guardians this possibility is used rarely. In most cases the parents remain guardians and the new caregivers, after the guardianship orders in favour of chief executive are discharged, are appointed as additional guardians.

\footnotetext{
403 In some cases their rights are suspended under s 114 of the Children, Young Persons, and Their Families Act or they may be additional guardians.

404 Family Law Service - Guardianship (online looseleaf ed, LexisNexis) at [6.204 Fn 5]; see also [6.205]: "extremely rare".
} 
Pursuant to s $16(5)$ the several guardians have to work in cooperation: ${ }^{405}$

However, in exercising (or continuing to exercise) the duties, powers, rights, and responsibilities of a guardian in relation to a child, a guardian of the child must act jointly (in particular by consulting wherever practicable with the aim of securing agreement) with any other guardian of the child.

The ability to cooperate is seen "as an essential ingredient" for people acting as guardians. ${ }^{406}$ The obligation to work together can lead to different problems. Where birth parents do not accept the new circumstances they might be not able or willing to agree on certain matters. Furthermore, this means that the actual caregiver has to ask for permission to make decisions important for the child, for example, choice of school, extracurricular activities, decisions about medical treatment. Even where foster parents have a parental order in their favour, different aspects cannot be decided by them without the consent of the other guardians. This can lead to situations where the child is not allowed to participate at events that his or her foster siblings are. The ability of a child to understand the different treatment is limited. Furthermore, the feeling of belonging and being part of the family may be destroyed. To allow, or indeed foster, developments, which will lead to disruption of that new family setting, can damage that sense of belonging. ${ }^{407}$

Where foster parents have to deal with uncooperative birth parents this must have an impact on the child. Also, this could lead to situations where foster parents are no longer willing to cooperate with birth parents, maybe because they have the feeling that the parents do not act for the benefit of the child, just to make the "work" more complicated for the foster parents or maybe because they do not agree with the way of life of the birth parents at all. This can jeopardise the placement.

As examined, the provisions for a resolution of a dispute are not sufficient. Even though courts try to avoid hearings and try to solve a dispute through mediation and counselling, this is every time an intervention in the placement. On the other hand, neither is a potential conflict between guardians sufficient ground to remove a parent as a guardian, ${ }^{408}$ nor to decline the appointment of foster parents as additional guardians. ${ }^{409}$

\footnotetext{
$405 \quad$ Care of Children Act 2004, s 16(5).

406 See AH v Chief Executive of the Ministry of Social Development FC Timaru FAM-2003-003-000172, 28 August 2009 at [58].

$407 \quad$ A v Ministry of Social Development [Access] [2009] NZFLR 625 at [58].

$408 \quad$ Moyle v Child, Youth and Family FC Papakura CYPF055/4-6/96; 21/98, 6 August 2002 as cited in Brookers Family Law - Child Law (online looseleaf ed, Brookers) at [CC27.08]. 
In addition, s 16(6) declares that: "Subsection (5) does not apply to the exclusive responsibility for the child's day-to-day living arrangements of a guardian exercising the role of providing day-to-day care."

It has to be noted, of course, that additional guardianship: ${ }^{411}$

... gives practical effect to the principles in subparas 5(a) and 5(c) [of the Care of Children Act], recognising that [the child] has both biological and psychological parents, as well as legal and psychological guardians making decisions in relation to [the child's] life.

However, in the case of a permanent placement there are mostly two issues. The first is the relationship between child and birth parents which "is of utmost importance, and must whenever possible be nurtured." ${ }^{412}$ Secondly, if the child is settled in a new family environment, this family placement "should suffer the minimum disruption." 413 Again, it is a question of balance between identity and security. Even though there is not a fits-one-fits-all solution, a secure upbringing and the experience of a family might be more important than the child's identity, which can be supported in different ways, even though the parents do not play a big role in the child's life.

It is always harder to make a decision when several parties are part of the decision-making process. Where they are not willing to work together it seems to be impossible. That they have to work together and have to act for the child's welfare cannot change the human nature. At last, where foster parents care for a child for a long duration, as is the case with a permanent placement, the child may have a closer emotional link to them than to the birth parents. The foster parents may know the child and the child's needs better than the birth parents. Should not the person who cares for the child, who knows the child and who is accepted or seen as the responsible person, make the decision?

\section{$2 \quad$ Role of birth parents}

"Beyond doubt, the natural order [and a prima facie presumption are] that children are best brought up by a natural parent or parents." ${ }^{414}$ Furthermore, normally parents and to be with

\footnotetext{
410 Care of Children Act, s 16(6); see below chapter VI A 1 (a) at 79 for further explanations.

$411 \quad$ PED v MHB [Whangai: Final Parenting order] [2012] NZFLR 35 at [66]

$412 \quad$ See A v Ministry of Social Development [Access] [2009] NZFLR 625 at [18].

$413 \quad$ See $A v$ Ministry of Social Development [Access] [2009] NZFLR 625 at [18].

$414 \quad K v G$ [2004] NZFLR 1105 at [22]; Re D (an infant) [1971] NZLR 737 at 740; $J$ and Another $v$ and Others [1969] 1 All ER 788 at 832 per Lord Upjohn.
} 
them is part of the child's welfare. ${ }^{415}$ Where the relationship between child and parent has developed fully and usually, it can be said that: ${ }^{416}$

... the parent knows the child best, loves the child most, and is best fitted to care for him or her. It can also be said that the child is most likely to be bonded to the parent in the same way, and will flower under the parent's care. Where the parent/child relationship is less well developed, and others have shared in the child's care ... neither assumption can be made as confidently.

Furthermore, where the: ${ }^{417}$

... parent's custody ... would be in some important respects disadvantageous to the child ... [the] parent is by character or conduct unfit to the custody of the child[,] is lacking in affection for the child or has been unmindful of his parental duty towards it [or where there] has been an abdication by the parent of parental authority in such a way that the court will not allow the parent to resume it [the presumption is displaced.]

"Parents [do not have] a pre-eminent position or ... an exclusive 'right' to the custody of the child when the future of that child is being considered by the Court." 418

However, Cooke ${ }^{419}$ stated that s 5 provides arguments in favour of the birth parents when a child is permanently placed: s 5(a) refers to the birth parents as well as to the new caregivers using the word "parents" because there is still a legal relationship between them and the child. Mentioning the continuity in development and upbringing could also be interpreted as maintaining contact with the birth family, especially the use of the words "in particular" shows that there should be continuity in the relationship with the birth parents and, furthermore, this could be used as an argument in favour of contact with the birth parents. At last, the references to the wider family cover the child's right ${ }^{420}$ to contact with members of the extended family.

Even interpreting the legal rules in favour of the birth family, as Cooke does, this cannot obscure the given facts: a permanent placement exists because the child has been taken away from the family inasmuch the birth parents were no longer able to care. Even with regard to the existing rules provided in the Care of Children Act, for example s 4(2) which states that

\footnotetext{
$415 \quad$ See $J$ and Another $v C$ and Others [1969] 1 All ER 788 at 832 per Lord Upjohn; see also $\operatorname{Re} D$ (an infant) [1971] NZLR 737 at 742.

$416 \quad$ Atkinson v Atkinson [1990] NZFLR 323 at 329.

$417 \quad \operatorname{Re} D$ (an infant) [1971] NZLR 737 at 740-741.

$418 \quad K v G$ [2004] NZFLR 1105 at [23]; A v Ministry of Social Development [Access] [2009] NZFLR 625 at [57].

419 Allan Cooke "Contact Issues for children who have been permanently placed out of their birth families" (2009) 6 NZFLJ 176 at 179.

$420 \quad$ Allan Cooke "Contact Issues for children who have been permanently placed out of their birth families" (2009) 6 NZFLJ 176 at 178 (emphasis added).
} 
"the welfare and best interests of the particular child in his or her particular circumstances must be considered", priority must be admitted to the relationship between the child and the new caregivers. Cooke stated: ${ }^{421}$

The welfare and best interests analysis will, in the end, see this outcome as there will be a reluctance on the party of the Family Court to see that new placement jeopardised.

There are two different reasons why a parent is not a guardian of his or her own child: Firstly, the parent never was. Pursuant to s 17(2):

... the child's mother is the sole guardian of the child if the mother was neither (a) married to, or in a civil union with, the father of the child at any time during the period beginning with the conception of the child and ending with the birth of the child; nor (b) living with the father of the child as a de facto partner at any time during this period.

The second possibility is that the parents were removed as guardians under s 29(1)(a). It is stated that the Care of Children Act is inconsistent in relation to parents who are not guardians of their child. ${ }^{422}$ Section 5(a) states that the parents "should have the primary responsibility ... for their child's care, development, and upbringing". In addition, pursuant to s 5(c) "the child's care, development, and upbringing should be facilitated by ongoing consultation and co-operation among and between the child's parents and guardians". The inconsistency lies in the powers of the guardian: ${ }^{423}$

In contrast, the definitions of a guardian's powers in ss 15,16 repose the child's guardians the right to make important decisions for or with the child. Parents who are not guardians have no such powers and have no power to apply to the Court under s 44(1) to resolve a dispute between themselves and a guardian of the child.

In $J M N v R V G$ Judge Walker declared that it has "limited value" whether a parent who is not a guardian is consulted on the question of an application for a re-hearing. ${ }^{424}$ On the one hand, this is contrary to the principles contained in s 5(a) and (c). ${ }^{425}$ On the other, even though the parent could apply for a parenting order, this does not provide him or her with the responsibilities and rights of a guardian in relation to the child: ${ }^{426}$

\footnotetext{
$421 \quad$ See also Allan Cooke "Contact Issues for children who have been permanently placed out of their birth families" (2009) 6 NZFLJ 176 at 178.

422 Brookers Family Law - Child Law (online looseleaf ed, Brookers) at [CC16.15].

$423 \quad$ At [CC16.15].

$424 \quad J M N v R V G$ [2008] 1 NZLR 40911 at [38].

425 See Brookers Family Law - Child Law (online looseleaf ed, Brookers) at [CC16.15].

426 See Brookers Family Law - Child Law (online looseleaf ed, Brookers) at [CC16.15].
} 
New Zealand family law has long attached separate rights and responsibilities to a parent's role qua parent and his or her role qua guardian. While this separation has advantages, it does leave the parental non-guardian in a somewhat ambiguous position.

Being a parent of someone else is a (biological) fact which cannot be eliminated, although the rights and responsibilities normally connected with that fact can be subject to change. The principles in s 5(a) and (c) should be seen as an establishment of objectives, which arises from the nature of things. Parents as "causer" should have the primary responsibility. Yet, if they prove themselves undeserving, their rights - which they only have for the benefit of the child - must be taken to protect the child. Therefore, the separation of parents and guardians itself is important. Being a biological father or mother cannot be taken, being a guardian can. Parents removed as guardians have acted not for the benefit of the child, so that they have their basic rights initially forfeited, even though they may be still the parents of the child concerned. This is reflected in s 16. So the question of whether a parent, who lost guardianship, should be consulted and should have the right to work jointly together with other guardians, can only be answered in the negative. Therefore, s 16 has to be seen as a justified exception to the general principle in s 5. The Care of Children Act may be inconsistent only where a parent never has been a guardian.

As stated, the focus has to be on the child and it has to be determined what serves best the child's welfare and best interests. The blood tie and the general assumption that a relationship with birth parents will benefit the child's welfare should not be stressed too much. It is said that biological relationship and psychological bond "must both be weighted in considering the interests of the child [and neither] is entitled to any presumptive superiority when it comes to assessing the welfare of the child." ${ }^{427}$ It has to be borne in mind that "parents have a special relationship with the child not because of their parental status but because they have formed emotional bonds with the child and have become an important part of the child's life and experience." 428 The psychological bond seems to be more important than the blood tie.

In $S v E$ the court was unable to determine who the psychological parent was and took a look at other factors such as the capacity and ability of the parent to develop a child's potential ${ }^{429}$ or with other words "what positive contribution the parent can make to the child's care, development, and upbringing". ${ }^{430}$ Applied to a child in permanent foster care, especially, one placed in early childhood, the biological connection loses its importance. If a child is placed early and/or for a long time with other caregivers there may not be a close relationship with birth parents. Furthermore, the assumption of a close relationship may be only based on the

\footnotetext{
$427 \quad$ A v Ministry of Social Development [Access] [2009] NZFLR 625 at [32].

428 Brookers Family Law - Child Law (online looseleaf ed, Brookers) at [CC48.41].

$429 \quad$ See for example $S \vee E$ (1981) 1 NZFLR 73 at 75 in a dispute between the birth mother and birth father about custody. 
idea that there has to be such a connection because of the biological connection. The relationship between child and caregiver can be more important than the one with the birth parents, only because they have formed an emotional bond. Furthermore, the ability and capacity of the new caregivers to care for the child may be better and, therefore, they would serve the welfare and best interest of the child more than the birth parents could do. This is more important, keeping in mind that the children concerned in most of the cases have a difficult legacy caused by their birth parents. Moreover, children with such a legacy can only rework their early negative experiences in the context of secure relationships. ${ }^{431}$

Section 4(2) of the Care of Children Act determines that the specific child has to be taken into account and this leads to the conclusion that the principles contained in s 5 have to be weighted in the context of the child's special circumstances. In cases where the child's attachment to the foster parents is stronger than to the birth parents, the societal expectation which says that the biological parents who have "produced" the child should have the responsibilities and, furthermore, the rights to bring up the child cannot outweigh the child's welfare. Considering the special circumstances, the foster parents - as psychological parents - have to have the legal support.

Where a child is placed with foster parents it may be important that the child has contact with the birth parents. ${ }^{432}$ This enables the child to understand his or her background and identity. ${ }^{433}$ This contact, however, is not granted "for the purpose of allowing a biological parent to develop a relationship in a way which will ultimately lead to a young child being returned to that biological parent." ${ }^{434}$ Further on, Asher J declared that: ${ }^{435}$

... such an approach would be contrary to the interests of the child. This is because the child will end up with confused loyalties and families ties. It is in a young child's interest that it has a predominant connection with the permanent placement family with which the child lives.

One of the guiding principles is that the child should develop a feeling of belonging. ${ }^{436}$ Any development that disrupts the permanent placement is detrimental to the sense of belonging and may not be beneficial for the child's welfare. ${ }^{437}$ This has to be considered determining contact between child and birth parents.

\footnotetext{
$431 \quad$ Nicola Atwool "Permanency: what children need" (New Zealand Law Society Care and Protections Orders and CYFS Seminar, Wellington, 25 October 2012).

$432 \quad$ See above chapter IV E at 20 and chapter V A 4 (b) at 57 regarding contact issues.

433 A v Ministry of Social Development [Access] [2009] NZFLR 625 at [57].

$434 \quad$ At [58].

435 At [58].

436 See Children, Young Persons, and Their Families Act, s 13(f)(iii).

437 See A v Ministry of Social Development [Access] [2009] NZFLR 625 at [58].
} 
Furthermore, assuming that a return of the child to the birth family is automatically in the child's interests would give the blood tie priority over the welfare and, consequently, has to be refused: ${ }^{438}$

That is not permissible, because it makes the blood tie and parental and family rights, rather than the child's welfare and interests, the deciding factor. Parental and family rights are relevant only to the extent that they are exercised for the welfare and interests of the child.

\section{$3 \quad$ Summary}

In the end, birth parents can play a role on the life of their child. First, they remain guardians in most of the cases, so still have rights and responsibilities, even though a third person will exercise them. Secondly, they can apply for contact and access orders, as well as parenting orders. However, the child's welfare has to be the deciding factor. Especially in cases of permanent placements, foster parents may have become the psychological parents of the child. This relationship has to be legally recognised, supported and protected. The child's welfare is the deciding factor, not the blood tie or the "right" of a parent.

\section{Māori Perspective}

Besides the two statutes there is another issue important in New Zealand: ${ }^{439}$

[All] Acts dealing with the status, future, and control of children are to be interpreted as coloured by the Treaty of Waitangi. Family organisations must be said to be included among those things which the Treaty was intended to preserve and respect.

From a historical point of view children were cared for not only by their birth parents. The whole family was responsible for the care of the child. Children were and are not considered as in their parents' exclusive possession: "Indeed the idea of possession and exclusion, separately or in association outrage Māori sensibilities." 440 They belong to the whānau, hapū and iwi and are not considered as the property of their parents. ${ }^{441}$ Children are seen as toanga that are both tangible and intangible and as such have "to be treated with respect, responsibility, love, and care by all members of the group." ${ }^{442}$ It is expected that the care for a

\footnotetext{
$438 \quad \operatorname{Re} B$ (children) [1992] NZFLR 726 at 758.

$439 \quad B P \vee D G S W$ [1997] NZFLR 643 at 646.

$440 \quad$ Temple v Barr and Holborn HC Wellington CIV-2010-485-000561, 24 August 2010 at [117].

441 Joan Metge and Jacinta Ruru "Kua Tutū Te Puehu, Kia Mau: Māori Aspirations and Family Law Policy" in Mark Henaghan and Bill Atkin (eds) Family Law Policy in New Zealand (3rd ed, 442 LexisNexis, Wellington, 2007) 47 at 52. At 53.
} 
child is shared with members of the whānau. ${ }^{443}$ Furthermore, other whānau members take over the role of parents from feeding to discipline the child. ${ }^{444}$ Where others than parents or grandparents primarily care for the child for a significant period, this is called whāngai. ${ }^{445}$ The expression: ${ }^{446}$

... whāngai is derived from the term to feed or look after or to care. It has now been extended to mean to foster or care for a child that is not one's own. In the specific context of Māori children and childcare, it is more appropriate to use the word matua whāngai which is the well known practice of one whānau taking over and fostering a child usually of the same whakapapa and bringing up that child as one of the adoptive family, but still mainly in a care and fostering role.

Again, this has a more holistic whānau rather than a possessory approach. ${ }^{447}$ Such a placement is in most cases informal and not secured by a court order. ${ }^{448}$ The general expectation for such an agreement is that it is short-term and that the child will return to the birth parents. ${ }^{449}$ The reasons for such a placement may differ: parents are unable to care for the child (mental health, drugs, alcohol), ${ }^{450}$ there is a risk for the wellbeing of the child ${ }^{451}$ or the parents and the future caregivers agree (often before birth) that they bring up the child as their own, because close relatives, childless themselves, expressed a wish or willingness. ${ }^{452}$ Some see it as "an informal type of adoption without the formalities required under the Adoption Act 1955." "453 This arrangement is sometimes translated into English as "adoption" regardless of whether it is formalised under the Adoption Act or not. ${ }^{454}$

According to Atwool, 45 per cent of the children in care are Māori and of these 45 per cent are in kinship care. ${ }^{455}$ Māori culture does not approve the severance of the child's legal relationship to the birth parents that adoption involves. ${ }^{456}$ The child has to know his or her

\footnotetext{
$443 \quad$ At 53 .

$444 \quad$ At 53

445 At 60

446 PED v MHB [Whangai: Final Parenting Order] [2012] NZFLR 35 at [6].

$447 \quad$ At [31].

448 At [8].

449 At [8].

450 At [9].

451 At [10].

$452 \quad$ At $[11]$

453 At [7].

454 Joan Metge and Jacinta Ruru "Kua Tutū Te Puehu, Kia Mau: Māori Aspirations and Family Law Policy" in Mark Henaghan and Bill Atkin (eds) Family Law Policy in New Zealand (3rd ed, LexisNexis, Wellington, 2007) 47 at 60.

455 Nicola Atwool "Participation in Decision-making: The Experience of New Zealand Children in Care" (2006) 3 Child Care in Practice 259 at 260, data from 2000: 24 per cent of children under the age of 18 were identified as Māori in 2001.

456 Joan Metge and Jacinta Ruru "Kua Tutū Te Puehu, Kia Mau: Māori Aspirations and Family Law Policy" in Mark Henaghan and Bill Atkin (eds) Family Law Policy in New Zealand (3rd ed, LexisNexis, Wellington, 2007) 47 at 61.
} 
true whakapapa and connections to establish his or her identity and group membership. ${ }^{457}$ Nevertheless, Māori use adoption orders to secure their children into their whānau. ${ }^{458}$ According to Smith, between 1995 and 2000, 362 out of 700 final relative adoption orders related to Māori children and 93 per cent of them where adopted by relatives where one or both adoptive parents were of Māori descent. ${ }^{459}$ She concluded that this shows "that the protection or security adoption offers must outweigh the legal cut in identity in these instances." 460

Even though all Acts have "to be interpreted as coloured by the Treaty of Waitangi", ${ }^{461}$ the first and paramount consideration is the child's welfare. This can lead to circumstances in which the welfare overrules the Māori heritage. ${ }^{462}$ However, the cultural background and the special position within a whānau must be kept in mind deciding about the child's placement. ${ }^{463}$ Therefore, it is important that the new caregiver recognises the responsibility to bring up the child with knowledge of the cultural heritage, language and tikanga as well as tribal history and whakapapa. ${ }^{464}$ Hence, the most suitable placement seems to be a kinship placement.

Besides this general approach both Acts refer to the whānau, hapū and iwi. ${ }^{465}$ The Children, Young Persons, and Their Families Act strongly favours a kinship placement stating that the child should return to whānau, hapū or iwi ${ }^{466}$ or should at least live in a family-like setting in which the links with whānau, hapū and iwi are maintained and strengthened where a child cannot be returned. ${ }^{467}$ Where this is not possible, the child should live in a family group in which his or her personal and cultural identity is maintained. ${ }^{468} \mathrm{~A}$ person who is a member of the child's whānau, hapū or iwi should be given priority when deciding about the person who should care for the child. ${ }^{469}$ According to $\mathrm{s} 5$ of the Care of Children Act, it is relevant for the child's welfare to be in a stable and ongoing relationship with whānau, hapū and iwi, ${ }^{470}$ which has to be preserved and strengthened ${ }^{471}$ and that the child's identity including culture

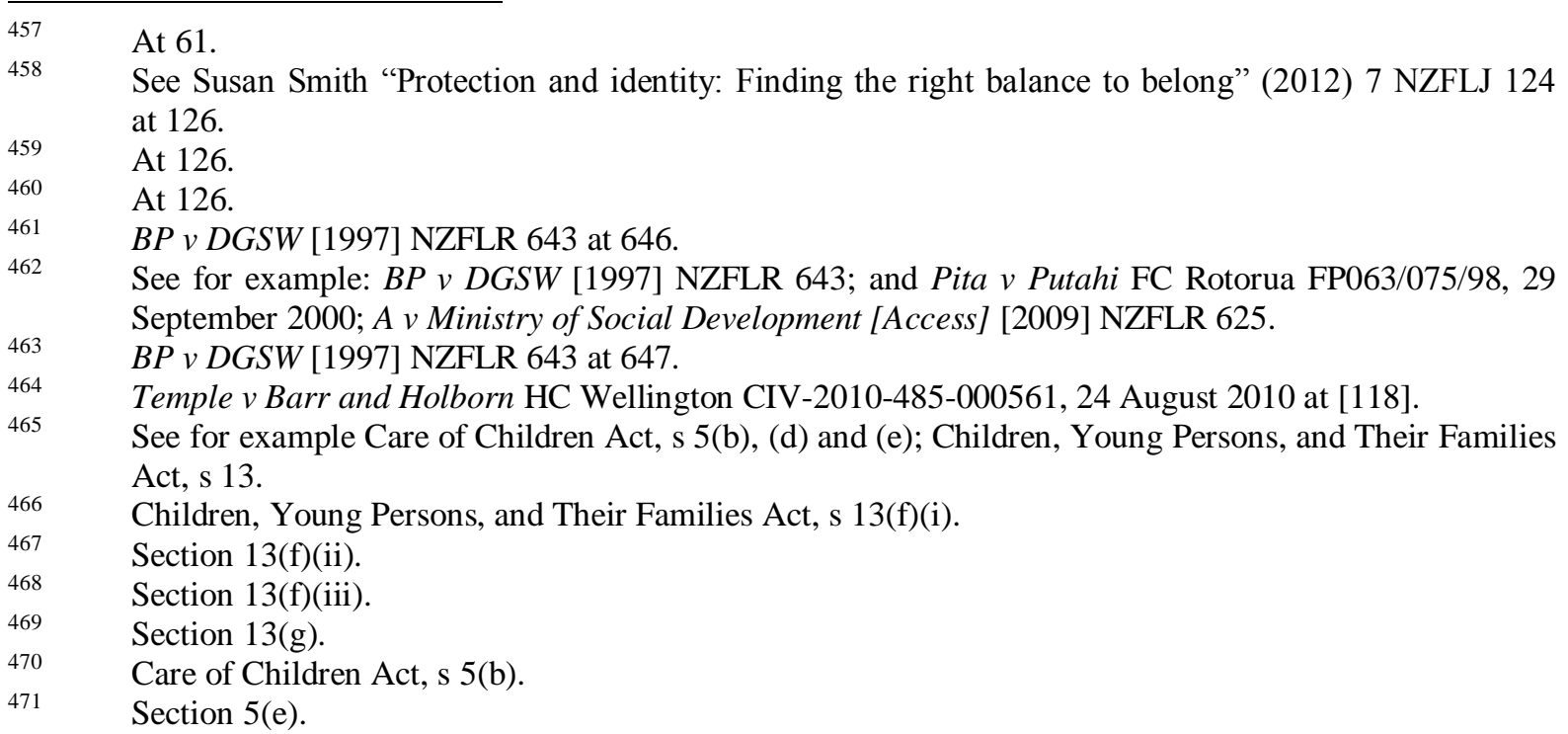


and language is preserved and strengthened. ${ }^{472}$ In the case law the important role is recognised. ${ }^{473}$

Summarising this, the child's relationship to whānau, hapū, iwi is important and has to be maintained. Adoption may not be a perfect solution as it severs the legal tie to the birth family. This is not in accordance with the Māori beliefs. Therefore, a more appropriate solution has to be found. Nevertheless, kinship care may have positive effects for the child, especially regarding identity, culture and continuity, but in many cases kinship carer are older than foster parents, more likely to live in poverty and less educated. ${ }^{474}$ Especially, when considering a kinship placement it should be kept in mind that the focus has to be on the child's welfare and not a family reunification. Furthermore, to prefer kinship care can lead to situations where a child is placed outside of his or her community with strangers he or she never met before, ${ }^{475}$ which should not be the solution, especially, where familiar non-kinship carers might be available. Obviously, the same problems as in a Pākehā family can occur, when relatives become additional guardians.

\section{The Practice of Child, Youth and Family}

Child, Youth and Family, as an agency of the Ministry of Social Development and, thereby, responsible for care and protection, offers support for children in different life situations.

The Ministry established a permanency policy which envisages that a permanency plan is made for a child for whom a permanent care arrangement came into question within a defined timeframe. This was updated in 2010 by the Home for Life policy.

The purpose of this policy is to create a Home for Life for children who cannot return home "where they feel loved, wanted and valued." 476 According to the policy for every child concerned a special plan has to be developed, including permanent care goals. Firstly, the child should return home. However, if this not possible, the child should be placed with family/whānau. Placing children with whānau shows different advantages. "This placement will help maintain family links, family history and a sense of belonging, as well as fostering the child's cultural and spiritual needs." 477

\footnotetext{
$472 \quad$ Section $5(\mathrm{f})$.

473 See for example Re $T$ (1999) 19 FRNZ 11, where a Māori baby should be cared for by a couple in Australia. Before the court made a decision a family conference had to be held. As mentioned above, this dissertation does not discuss family group conferences due to the word limit.

474 Marie Connolly “A kinship care literature review” (2003) 25 Social Work Now 24 at 26-27.

475 Also Nicola Atwool "Permanency: what children need" (New Zealand Law Society Care and Protections Orders and CYFS Seminar, Wellington, 25 October 2012).

476 Child, Youth and Family "Permanent Care and creating a Home for Life" (3 April 2012) <www.practicecentre.cyf.govt.nz>.

477 Child, Youth and Family "Securing a bright and safe future in home for life" <www.practicecentre.cyf.govt.nz>.
} 
To secure the Home for Life there should be legal orders in favour of the new caregiver in place. According to Child, Youth and Family, in cases of placements with family or whānau this might be problematic because of cultural beliefs or the Home for Life parents do not want to disturb the relationship between the birth parents and the child. ${ }^{478}$ However, the policy suggests discharging the legal orders in favour of the chief executive in these cases without making orders in favour of the new caregivers, which means that the birth parents legally gain back any decision-making powers. Hence: ${ }^{479}$

The natural parents need to agree to the permanency of the placement with the family/whānau caregivers and a plan in place to cover any concerns that may arise around the natural parents wishing to resume the care of the child.

This cannot be the case if there is a conflict between the adults involved. Then legal orders in favour of the chief executive should remain: ${ }^{480}$

The child's needs, including safety [are] paramount. If these conditions are not satisfied then it is in the child's best interests to remain in the custody of the chief executive for as long as this meets the child's needs.

If this is also not an option "home for life with non-family/whānau becomes the primary goal". ${ }^{481}$ In CAS $v$ Chief Executive of the Ministry of Social Development it was stated that: ${ }^{482}$

It follows that permanency for a child outside the family as is proposed in a 'Home for Life' package should be considered only when the point of time is reached where there is either acceptance that a child's parent or guardian cannot properly re-assume the care of the child or alternatively the Court determines that issue.

Keeping in mind that a permanent placement does not mean an end of one family and the beginning of another, the policy states that it is important to involve the whānau in the decision-making process and, furthermore, when choosing the best caregivers issues as ethnicity, religion and maintenance of ties with the birth family have to be considered. ${ }^{483}$

\footnotetext{
478 Child, Youth and Family "Securing a bright and safe future in a home for life" <www.practicecentre.cyf.govt.nz>. <www.practicecentre.cyf.govt.nz>.
} 
In the question concerning legal orders for non-family/whānau caregivers they prefer legal orders under the Care of Children Act. ${ }^{484}$ A combination of different orders should be chosen in order to meet the needs of the present child, whereupon this all should happen in collaboration with the Home for Life parents, birth parents and family/whānau. This procedure aims to secure the relationship between the Home for Life parents and the child and gives them the opportunity to make day-to-day care decisions. ${ }^{485}$ Legal orders in favour of the chief executive should not remain. ${ }^{486}$

In addition, because of the shared guardianship responsibilities the policy declares that continuing meetings between whānau and caregivers should take place, not only to determine the form of Home for Life, even more to decide how to manage these responsibilities, eventual contact issues and how to address conflicts. ${ }^{487}$ One aspiration seems to be that the child develops a feeling of belonging to both: whānau and Home for Life family. ${ }^{488}$

The Home for Life is realised when the child lives in an endorsed placement, the caregiver has obtained legal orders to secure the placement and custody orders in favour of the chief executive are discharged. ${ }^{489}$ According to Child, Youth and Family custody orders under the Care of Children Act, now referred to as parenting orders, are the best way to give the new caregivers responsibility for the day-to-day care. ${ }^{490}$ The fact, that these orders will not be reviewed secures the placement in recognising the child as a part of the new family and that a monitoring is not required. ${ }^{491}$ Furthermore, to achieve the appropriate legal status the new caregivers should become additional guardians, in addition to parenting orders. ${ }^{492}$ Child, Youth and Family sees sole guardianship (ideally under the Care of Children Act) as an appropriate legal instrument to secure the placement, when working with birth parent is not possible or they undermine the safety or wellbeing of the child. ${ }^{493}$

\footnotetext{
484 Child, Youth and Family "Securing a bright and safe future in a home for life" <www.practicecentre.cyf.govt.nz>.

485 Child, Youth and Family "Securing a bright and safe future in a home for life" $<$ www.practicecentre.cyf.govt.nz>; Child, Youth and Family "Use of Legal Orders to secure a home for life" (May 2011) <www.practicecentre.cyf.govt.nz>. <www.practicecentre.cyf.govt.nz>. 
Different problems arise with this policy: the orders to achieve permanency should be made under the Care of Children Act. Child, Youth and Family will no longer be part. This may lead to a more "normal" family-life feeling. However, this also means that there will no longer be a buffer between the caregivers and the birth parents. Foster parents may have to deal with birth parents by themselves directly.

Another issue is the (financial) support of foster parents. Without the Home for Life policy foster parents can receive financial support, if the child needs this, for example, for health and educational issues. Generally, this ends becoming part of the Home for Life policy. The declaration that the child is in need of care and protection will be discharged. This is a prerequisite for a services order under s 86 of the Children, Young Persons, and Their Families Act. Instead, the policy envisages that foster parents receive the Home for Life package. This includes a three year support. Inter alia, they receive a $\$ 2,500$ upfront payment and support to make contact to adjuvant agencies. ${ }^{494}$ For example, the payment shall "provide for the individual needs of the child." ${ }^{495}$ This policy is criticised. "The approach of the Ministry seems to be a blanket policy where individuals' circumstances are given scant attention. ${ }^{, 496}$ In the end, this may be detrimental for the child's welfare.

The provisions in the White Paper are intended to finalise the permanent Home for Life arrangement. ${ }^{497}$ One suggestion is to assure that the Home for Life parents "will be supported should the child's parents attempt to disrupt the placement." ${ }^{498}$ Unfortunately, it does not contain details about this assistance nor provisions for further support. In the following chapters, some proposals are put forward.

\footnotetext{
494 Child, Youth and Family "Home for Life support" (September 2011) <www.practicecentre.cyf.govt.nz>.
Child, Youth and Family "Home for Life support" (September 2011) <www.practicecentre.cyf.govt.nz>. PFMB v JJB [services orders] [2012] NZFLR 837 at [8]. Paula Bennett, Ministry of Social Development "The White Paper for Vulnerable Children" (Wellington, 2012) volume II at 124. Paula Bennett, Ministry of Social Development "The White Paper for Vulnerable Children" (Wellington, 2012) volume II at 125.
} 


\section{Sole Guardianship for Foster Parents?}

Sole guardianship means granting exclusive responsibilities and duties to a person to the exclusion of third parties. Where others have had such responsibility before this order (typically birth parents), their rights are at least suspended. ${ }^{499}$

\section{A Joint Cooperation}

\section{When foster parents are additional guardians}

As shown above, additional guardians have to act jointly with other guardians under s 16(5) of the Care of Children Act 2005. This provision causes different problems: (1) The exception in s 16(6) of the Care of Children Act is not clear and different interpretations are possible. This could destabilise the arrangements. (2) The relationship between the adults involved could make joint collaboration difficult, if not impossible.

\section{(a) Day-to-day living arrangements}

Section 16(6) of the Care of Children Act states that s 16(5) "does not apply to the exclusive responsibility for the child's day-to-day living arrangements of a guardian exercising the role of providing day-to-day care." This exception can be interpreted in two different ways: First, it applies to the guardian who in fact is providing the day-to-day care or secondly, to the guardian who is exclusively responsible for providing the day-to-day care because of a parenting order. ${ }^{500}$

Assuming a parenting order exists in favour of the long-term foster parents, there is no difference between both interpretations. In both cases the birth parents would be excluded and joint collaboration is not necessary. On the other hand, if there is no parenting order granting the foster parents day-to-day care the two questions to answer will be how to interpret s 16(6) of the Care of Children Act and whether or not the foster parents are exclusively responsible.

Even though these problems can be solved, s 16(6) only refers to the day-to-day living arrangements. Actually, this term is not legally defined in the Act. This can evoke further problems. The question is what areas of life are included. The interpretation depends on the different points of view. While foster parents will choose a broader definition, the birth parents, who are interested in the care of their child, will try to keep the area as narrow as possible, to obtain a larger say in the child's life.

\footnotetext{
$499 \quad$ For more details see the recommendations below in chapter VII A at 89.

500 See Family Law Service - Guardianship (online looseleaf ed, LexisNexis) at [6.201].
} 
Nevertheless, there are points which cannot be interpreted as part of "the child's day-to-day living arrangements" and therefore, the birth parents and the foster parents would have to act jointly together, in particular by consulting.

Besides the more general approach that long-term foster parents who live daily with the child know the needs, strengths and weaknesses better than birth parents whose roles in the child's life have waned, there are certain specific aspects to consider. A school enrolment may be not part of "the child's day-to-day living arrangements". Foster parents and birth parents would have to act jointly together in deciding what school the child should attend. This can be difficult, for example, if the child has special needs which can be better addressed in a special school, but are necessary for the child's welfare like special sports or music programmes or the attendance in a certain school may cause problems with an eventual contact with the birth parents because of distance. The religion of the child is also another issue to address. Of course, in the best case foster parents are members of the same religion in which the child was brought up by the birth parents. However, this may not be possible in cases in which the birth parents belong to two different religions and the foster parents only to one of them. Joint collaboration between the foster parents and the birth parents of another religion could prove difficult.

\section{(b) Involvement of a third party}

Joint collaboration means further that the guardians have to inform a third party ${ }^{501}$ about the agreement or they have to refrain from the intended action. Anyway, in most cases the third party will not have any reason to doubt the guardian's ability to act. This legal situation: ${ }^{502}$

... effectively puts the onus on an objecting guardian to take the initiative of referring the matter to the Court and, in the meantime, making his opposition to the decision known to the third party about to act on it.

\section{(c) Comparison with disputes between mother and father}

Another issue results from the case law relating to fathers applying for guardianship orders. In some cases the father did not have guardianship over his child and applied for an order in his favour. The court denied him such orders. The reason for dismissing these applications was the relationship between mother as primary caregiver and the father. ${ }^{503}$

\footnotetext{
$501 \quad$ For example a school principal, directors of clubs the child wants to join, parents of friend of the child. 502 Family Law Service - Guardianship (online looseleaf ed, LexisNexis) at [6.201].

$503 \quad$ In $K \vee B$ [1991] NZFLR 168 the child was the result of a brief sexual relationship. The mother wanted the child adopted. The father was inter alia not appointed as guardian because it would have been contrary to the child's welfare.
} 
In Skedgwell $v$ Ewington it was held that granting the step-father guardianship responsibility "would lead to continued guardianship disputes". ${ }^{504}$ The lawyer for the father argued that it was necessary to appoint him as an additional guardian because the mother did not communicate with him and he was concerned about several health and welfare issues. ${ }^{505}$

To sum up, a conflict between both birth parents can be a reason not to grant the biological father guardianship rights and responsibility over his own child, mainly because cooperation cannot be expected. As examined, this is not the case in the situation between foster parents and birth parents. In the end, this could be detrimental to the child's welfare and best interests. The question coming to mind is why good collaboration is expected in a case of a permanent placement or even more importantly can good collaboration to the benefit of the child be expected?

\section{(d) Resolving disputes}

The Care of Children Act provides in s 44 the possibility to apply for a court direction where there is a dispute between guardians. ${ }^{506}$ It should be kept in mind that a proceeding is a possible threat to the security of the placement of the child. Furthermore, the Act does not provide a provision to enforce a direction. The court can make several orders. However, this means that more and more persons get involved and this may complicate the upbringing of the child and the decision-making process, especially where the identification of the responsibilities is not clear. The same applies under the Children, Young Persons, and Their Families Act, where pursuant to s 115 the court may make an order to solve a dispute. However, it would be more beneficial for the child to avoid disputes. Therefore, appropriate provisions should be in place which not only try to solve disputes (especially in an insufficient way), but prevent future conflict.

\section{When foster parents have a parenting order in their favour}

Where foster parents are not additional guardians, s 44 causes another problem. Foster parents who are not guardians cannot apply for a court direction under s 44 and cannot be party of such a proceeding. When there is a dispute between both parties the provisions are not sufficient to resolve it; at least there is no provision at all. The question is: Who should decide in such a conflict? Does a parental order overrule guardianship rights? An explicit regulation defining the relation between both does not exist. Section 16(6) of the Care of Children Act grants exclusive responsibilities, but not every decision that has to be made can 
subsumed under "the child's day-to-day living arrangements". Therefore, in several situations the parties concerned are left without legal provisions.

A parenting order gives the person, in whose favour it is made, the power to exercise parental responsibility. It does not transfer the responsibility itself. Any other interpretation would lead to the consequence that parents would be deprived of their rights in every case where someone is granted a parenting order; this would have the effect of a sole guardianship. Further, this would mean that parental rights are weak and not strongly secured, because for a parenting order no grave reason is needed. This cannot be the case. Hence, even where a parenting order exists, the whole exclusion of parents does not exist. Parents as guardians still have their rights and furthermore, a guardianship right is a stronger position than the one conferred by a parenting order. Parents as guardians still have a say in the upbringing of their child and may as long as they are guardians "insist in some form of involvement with and control of the children." ${ }^{507}$ They still have the right to bring up the child except on a day-today basis. ${ }^{508}$

In addition, it should also be kept in mind that not every part of the life of the child can be dealt with by a parenting order. Some aspects were identified that still belong to the responsibility of all guardians even though a comprehensive parenting order is in place. This was, for example, stated for a change of residence. ${ }^{509}$

Finally, just because a parenting order in favour of the foster parents is in place this does not mean that they do not have to work together with the guardians. A parenting order is not stronger than a guardianship order. If guardians have to work together then a person whose position was "only" granted by a parenting order has to do so as well. Furthermore, according to s 5(c) of the Care of Children Act, the parents and the permanent caregivers as "persons exercising the role of providing day-to-day care" should cooperate with each other. So even where there is a parenting order granting foster parents the day-to-day care, joint cooperation with other guardians is expected. As already mentioned, this causes additional stress for the child. Ongoing conflicts and proceedings cannot be in the best interests of the child. This could be prevented if it is clear from the very first that long-term foster parents can decide without consultation. ${ }^{510}$

\footnotetext{
$507 \quad A v D-G S W[1995]$ NZFLR 241 at 243.

$508 \quad$ See $A v D$-GSW [1995] NZFLR 241 at 246.

509 In the matter of AHRJ [2005] NZFLR 49 at [21]; Chief Executive of the Ministry of Social Development v BJG FC Hastings FAM 2009-020-447, 19 January 2010 at [38]. 


\section{B Advantages for the Placement of the Child}

Often it has been stated that "it is better to maintain the status quo and thus avoid unnecessary disruption in the children's lives when it is unknown what consequences of such change would bring about." "511 Furthermore, a "[family] placement is thought to minimise disruption while increasing the opportunity for family self-determination and the reintegration of the child within their immediate family." ${ }^{512}$ However, there are cases where reunification with birth parents is not possible and the child has to be placed with new caregivers even though this means a change and disruption in the first place. Where a child has to be removed this child should grow up in a stable and secure placement. Security of a placement can be achieved through "certainty of one person having ultimate responsibility for decisionmaking". 513

\section{$1 \quad$ Avoid disruptions}

As shown above, a placement can be disrupted by several applications parents may file, for example, to have contact with the child or to challenge a parenting order in favour of the long-term foster parents. Therefore, it might be necessary to protect the placement and thus also the child against disruptive attempts. ${ }^{514}$ In cases, where the chief executive was appointed as a sole guardian it was stated that: ${ }^{515}$

Further, sole guardianship may sometimes be the only way of achieving stability and security in a family that cannot be "patched up", ${ }^{516}$ and sometimes sole guardianship may be used as a holding measure pending later directions by the Court. ${ }^{517}$

\section{$2 \quad$ Family-like feeling}

There may be several situations in which the family-like life with the foster family can be disturbed because of a joint guardianship between birth parents and foster parents. This might be the case where the foster family wants to travel. A holiday with the foster family may not be included in the day-to-day care. Another example might be the medical treatment of the child which can be made complicated because of different religious views and a general

\footnotetext{
$511 \quad$ TTH $v$ JTAH [Parenting order] [2011] NZFLR 369 at [40].

512 Allan Cooke "Contact Issues for children who have been permanently placed out of their birth families" (2009) 6 NZFLJ 176 at 177.

$513 \quad D-G S W v R$ (1997) 16 FRNZ 357 at 373; In the matter of $C$ [2003] NZFLR 769 at [41].

$514 \quad$ Re the P Children (No 2) (1992) 9 FRNZ 93 at 109.

$515 \quad$ Family Law Service - Children, Young Persons, and Their Families (online looseleaf ed, LexisNexis) at [6.578].

$516 \quad D S W v R$ DC Auckland CYPF 004/53/93, 22 February 1994 as cited in Family Law Service - Children, Young Persons, and Their Families (online looseleaf ed, LexisNexis) at [6.578].

$517 \quad$ DSW v T [1998] NZFLR 177 as cited in Family Law Service - Children, Young Persons, and Their Families (online looseleaf ed, LexisNexis) at [6.578].
} 
parental attitude in favour or against contraception, termination of pregnancy, blood transfusion. ${ }^{518}$ Different treatment, especially in comparison to other children of the foster family, can be detrimental to the child's welfare and best interests.

Furthermore, it may be difficult for foster parents to convey the child values if they do not comply with them. It can be said that these foster parents then might be the "wrong" foster parents for the child. However, the difficulty of finding of long-term foster parents should not be underestimated. Foster parents will never be like the birth parents. Therefore certain concessions must be made. In addition, the foster parents must be given some leeway.

Foster parents apply for a guardianship order for several reasons. Such an order can strengthen identification with the child. Furthermore, legal protection can be given to the relationship between them and the child to a certain extent. With a guardianship order their position would be legally recognised and they would have the "rights" to participate in the life of the child, to intervene and influence. ${ }^{519}$ Foster parents may become substitute parents to the child. As additional guardians they would be equated with the birth parents.

Sole guardianship responsibilities given to foster parents also mean more security and give the signal of more permanency. The placement would be less likely to be terminated which is also a positive effect for the child in developing a sense of belonging. Furthermore, granting foster parents guardianship rights can strengthen their commitment to the child they care for. This is important for the upbringing of the child: ${ }^{520}$

[The] threat of uplift (perceived or real) hanging over [the actual caregiver] could present a potential reason for their disagreement with [the child] either completely or emotionally, in part, to the detriment of [the child].

\section{$4 \quad$ Disregard of guardianship orders}

However, there may be cases where the new caregivers, even when it is a permanent placement, do not want to become guardians of the child at the moment. In Department of Child, Youth and Family Services $v$ GDB the aunt and uncle of the two children became the new permanent caregivers after the father murdered the mother. ${ }^{521}$ Judge Whitehead stated: ${ }^{522}$

\footnotetext{
518 Brookers Family Law - Child Law (online looseleaf ed, Brookers) at [CC16.10].

$519 \quad$ Skegdwell v Ewington [1992] NZFLR 614 at 650.

$520 \quad$ Ministry of Social Development v C-P F FC Kaikohe FAM-2008-027-000351, 26, 27 May 2011 at [40].

521 Department of Child, Youth and Family Services v GDB FC Nelson FAM-2003-009-4314, 02 November 2005.

$522 \quad$ At [35].
} 
... that the most appropriate guardians would be the aunt and uncle who are having care of the children and will continue with their care in the foreseeable future ... [Anyway, there is] reluctance [on the part of the aunt] to have the formal orders in her and her husband's favour and [she] wishes to deal at arms' length with her brother, who is the father of the children.

Nevertheless, the placement has to be considered as a permanent one, which also means that the responsible persons should be able to make decisions without delay and "acrimonious dispute". ${ }^{523}$ In the case, the Department of Child, Youth and Family Services remained sole guardian. ${ }^{524}$ However, the question is: Would it have been appropriate to give sole guardianship responsibilities to the aunt and uncle, for example, in regard to daily life decisions such as health treatment or, more ordinary, sport activities and memberships in clubs, and having the chief executive as guardian and simultaneously as "protective barrier" against disruptive attempts from birth parents as well as a supportive "third party"? It should be respected that foster parents who bring up a child with a difficult legacy refrain from guardianship orders to avoid direct disputes with birth parents and to have the chief executive as a buffer. Furthermore, having the chief executive involved can also mean more support. However, this should not be the reason to refrain from an application for a guardianship order. Rather support should be available in any case where necessary.

\section{$5 \quad$ Summary}

Granting sole guardianship responsibilities to a permanent caregiver can secure the placement. With the right protection, disruption and termination of the placement are less likely. Giving them the exclusive responsibility will strengthen their commitment to the child. Child, Youth and Family should be available as a buffer between foster parents and birth parents, if this is necessary.

\section{For the Benefit of the Child}

Another aspect in favour could be the child's own point of view. As stated above the child should be the focus. How does it look like for the child if the long-term foster parents, as the ones who have in fact cared for the child for a long time and may be the psychological parents for the child, have to ask strangers before making important decisions? In this context, consider a longer school trip. This may not be part of the child's day-to-day living arrangements. Another example could be medical treatment like a vaccination which may not be urgent and not absolutely necessary.

\footnotetext{
523 Department of Child, Youth and Family Services v GDB FC Nelson FAM-2003-009-4314, 02 524 November 2005 at [46]. At [46].
} 
The affected children have a difficult legacy which affects permanent placements. These children need ongoing support, not only financial also therapeutic in a lot of cases. Precisely for this reason they should have a secure basis to grow up and be "prepared to live an individual life in society". 525 This security can be achieved in granting one person the exclusive responsibility.

Once the decision is made that a child should be permanently placed this has to be taken as a fact and the child should be supported. This means that the child should be given the opportunity to experience a "normal" upbringing. The child has a right to grow and develop in the new family. A permanently placed child should be supported in developing emotional attachments to the new family. ${ }^{526}$

Foster parents as guardians would be legally bound to the child. Of course, depending on the age and maturity not every child will understand the difference. However, where foster parents are granted legal rights to care children feel more secure in their placement and this is beneficial for the welfare. ${ }^{527}$ Moreover: ${ }^{528}$

For fostered young people, the complicated question of who actually makes decisions in the complex network of birth, foster and corporate parents - and which 'parents' they need to influence and negotiate with - can exacerbate the problematic negotiation of autonomy.

Children need a secure relationship and a strong commitment, especially, when children have a difficult legacy. Furthermore, "children need secure and uninterrupted emotional relationships with adults who are responsible for their care in order to learn how to build secure attachments later in life". ${ }^{529}$ Being a child in foster care or a "CYFS child" gives children the feeling of being different. Moreover, knowing that they can be placed with new caregivers every time is stressful and detrimental. Giving more legal responsibilities to the actual caregivers can give them a more secure feeling. Granting sole guardianship responsibilities to the caregivers can avoid future disputes. It would be beneficial for the welfare because the child would not remain the centre of unremitting disputes for the rest of the childhood. ${ }^{530}$ The appointment is furthermore advantageous because "it will usually add

\footnotetext{
$525 \quad$ United Nations Convention on the Rights of the Child GA Res 44/25 (1989), preamble.

526 See Children, Young Persons, and Their Families Act, s 13(f)(iii).

$527 \quad$ See Jill Theresa Messing "From the child's perspective: A qualitative analysis of kinship care placements" (2006) 28 Children and Youth Services Review 1415 at 1432.

$528 \quad$ Gillian Schofield and Mary Beek "Growing up in foster care: providing a secure base through adolescence" (2009) 14 Child and Family Social Work 255 at 263.

529 Child, Youth and Family "Securing a bright and safe future in a home for life" <www.practicecentre.cyf.govt.nz>.

See Skegdwell v Ewington [1992] NZFLR 614 at 653, where the appointment as additional guardian was in question because of possible conflict.
} 
to the child's sense of security if the actual carers have legal duties and responsibilities for his or her care." 531 "The child has a right to a peaceful and stable upbringing, undisturbed by unnecessary conflict." ${ }^{, 532}$ When children have a right to be nurtured and cared for there has to be someone who has the duty. This should be the one who actually cares otherwise the child has a right against a third party who has to delegate the actual carer.

\section{Enduring Guardianship}

In 2000 the Law Commission recommended the creation of an "enduring guardianship". 533 This was thought of as an alternative to adoption. The purpose of this "enduring guardianship" was the adding of "a further adult relationship to a child's life rather than substituting parents". ${ }^{534}$ The links to the birth parents would persist ${ }^{535}$ and the legal parental status would not expire. ${ }^{536}$ It should be used by step-parents and family members where they assume the responsibility. ${ }^{537}$ The enduring guardian would have the same legal role as a natural guardian has. ${ }^{538}$ Moreover: ${ }^{539}$

The importance of enduring guardianship lies less in its legal significance than in the moral and social benefit of providing explicit recognition of the social importance of the extra parent in the child's life. Enduring guardianship provides a means by which a child's security and sense of familial belonging can be incrementally strengthened.

This approach was different, because it was meant to give family members or stepparents who actual care for the child legal responsibilities. This did not relate to children in need of care and protection placed away from birth parents. Also the other guardians would not have been limited or their rights would not have been suspended. ${ }^{540}$

\footnotetext{
531 Brookers Family Law - Child Law (online looseleaf ed, Brookers) at [CC27.04]. C v M FC Wanganui FP083/086/92, 12 November 1993 as cited in Brookers Family Law - Child Law (online looseleaf ed, Brookers) at [CC27.04].

533 Law Commission "Report 65: Adoption and its Alternatives: A Different Approach and a New Framework" (Law Commission, Wellington, September 2000) at [117]-[125].

$534 \quad$ At [118].

535 At [117].

536 At [119].

537 At [117].

538 At [125].

539 At [125].

540 According to s 114(2)(a) of the Children, Young Persons, and Their Families Act shall the rights of a person who is a guardian be suspended or have no effects where a sole guardian is appointed under s 110.
} 


\section{Recommendations}

Permanency as part of the child's welfare cannot be conferred by legal orders alone. The caregivers and birth parents attitudes' play a role as well. However, legal orders are part of the whole, influence the relationship between parties and give security to a certain extent.

As already examined, the law in general sees parents as the best persons to bring up their children. However, the "rights" of parents exist only where they are exercised for the benefit of the child. The fact that two people produced a child is not enough to grant them "more" rights. ${ }^{541}$ "It has often been said that children are not prizes to be awarded to a parent or others for good behaviour, nor are they to be used as sanctions or to punish for bad behaviour." 542

Where other persons fulfil the parents' role and the child bonds with them as if they were the birth parents, these persons should get legal security. This can be achieved through additional guardianship. Moreover, as shown, the removal of a parent as guardian is rare, so foster parents can usually be appointed only as additional guardians.

However, the disadvantages were examined above. Therefore, granting caregivers sole guardianship responsibilities can overcome these difficulties. Having only one set of parents responsible means that fewer disputes will occur. The caregivers would not have to work together with the birth parents in every case. The child would have a set of parents he or she could count on and develop a sense of belonging. Furthermore, the actual caregiver would no longer be "only the caregiver". The order would have the effect that the actual caregiver can decide, as would be the case in a "normal" child-parent relationship and the placement would be less likely to be interrupted. Furthermore, stressful and disruptive cooperation would not be necessary due to the sole responsibility of the caregiver.

The White Paper ${ }^{543}$ aims to increase stability and security of the permanent placement due to the introduction of a new guardianship order. Unfortunately, it fails to give detailed information about intended changes. It is unclear what is meant by limiting or reducing guardianship powers. Furthermore, same guardianship powers should be shared between birth parents and guardians. As examined, this leads to several problems. Recommendations to overcome this are not contained in the White Paper. Therefore, the White Paper raises several questions. The following suggestions seek to fill the gap created by the White paper.

\footnotetext{
$541 \quad$ See Tanner $v$ Edgill [2008] NZFLR 262; $K v G$ [2004] NZFLR 1105; Atkinson v Atkinson [1990] NZFLR 323; Taylor $v$ Wilson, Wilson and Wilson FC Hastings FP 020/172/96, 30 April 1998.

$542 \quad K \vee G$ [2004] NZFLR 1105 at [20]; Temple v Barr and Holborn HC Wellington CIV-2010-485000561, 24 August 2010 at [73].

543 Paula Bennett, Ministry of Social Development "The White Paper for Vulnerable Children" (Wellington, 2012).
} 
It is important to have a look at the specific child in the specific circumstances. The reasons why children are in care differ from case to case and the law has to recognise this. Therefore, the following suggestion distinguishes between different scenarios and provides different solutions. Four situations are distinguished: (1) the child was abused by birth parents; (2) the birth parents neglected their child; (3) due to mental illness or imprisonment, for example, parents are unable to fulfil their role; (4) the child lives with new caregivers due a private agreement. In all these case the following questions arise: When should the new caregivers become sole guardians? Are the rights of parents suspended or removed? Can parents challenge the court orders? Should they have contact with their child?

\section{A Sole Guardianship}

\section{$1 \quad$ Cases of abuse}

Where a child is victim of abuse parents forfeit their "rights". As soon as the placement is considered as permanent the new caregiver should become an exclusive sole guardian with appropriate rights. The guardianship rights of parents must be removed. The rights of the child to grow up in a non-violent environment, respecting the child's rights as, for example, the right to physical integrity and free development of the own personality, and supporting the child's welfare are the reasons for this. Of course, the human rights of parents and child require the least restrictive intervention. ${ }^{544}$ However, this cannot lead to an assumption that parents can treat the child as an object. In cases of child abuse parents should have no influences in the upbringing of their child. An abusive parent obviously repudiated parental responsibilities. Section 5(e) of the Care of Children Act and s 13(a) of the Children, Young Persons, and Their Families Act provide that the child has to be safe and protected, in some cases from birth parents. Removing the rights and responsibilities to care is one step to achieve this protection.

\section{Cases of neglect}

If the child is neglected by birth parents the new caregiver may become sole guardian as well as soon as the placement is considered as permanent. The reasons for neglect can differ. In some cases birth parents might not be interested, in other they are not able to care in an appropriate way for their child. Keeping in mind that the human rights require the least restrictive intervention, birth parents should be given the opportunity to improve. Therefore, parental guardianship rights should not be removed; they should be suspended at first. In the following 18 months parents should have the chance to show their improvement.

$544 \quad$ Andrew Bainham "Permanence for Children: Special Guardianship or Adoption?" [2007] Cambridge Law Journal 520 at 522. 
The proposal of 18 months stems from the law of the United States of America. ${ }^{545}$ Of course, the child's sense of time has to be considered. Therefore, it might be appropriate to set a different timeline for different stages of age. In the end, this is a question which has to be examined and answered from a psychological point of view as well which is beyond the scope of his paper. For this reason, the proposed 18 months should not be seen as unalterable. However, it should be kept in mind that the focus is on the child, but the parents may need time to change and this change may be for the benefit of the child long-term. On the other hand decisions have to be made within a certain time frame, because: ${ }^{546}$

Avoidable delay can be regarded as a form of systematic abuse for children less than five years of age because instability and uncertainty undermine any chance of recovery and may incur further damage.

Where parents fail to improve, their parental guardianship rights must be removed after this period. If they improve the suspension of their guardianship rights may be lifted, where they are able to cooperate with the new caregiver or even become, as a very unlikely event, guardians born in mind that in most cases after two years reunification with the birth family is doubtful. ${ }^{547}$ Whether or not parents should become additional guardians or "sole guardians" must be decided according to the child's welfare. Where the bonding to the foster parents has increased to a level where an interruption would be detrimental for the child, sole guardianship for the foster parents may be the appropriate solution. This suggestion seeks to find a balance between the human rights of parents and child on the one hand, and the rights of the child, on the other. The removal of parental rights after a certain time is necessary to give the child the opportunity to grow up in a secure family-like setting: ${ }^{548}$

The expectation of reunification may in itself cause some difficulties for both the young person and the birth family ... Sometimes it is the young people who become anxious because they realise that they have no wish to give up the foster family and the way of life that has defined who they have become during childhood and adolescence. They may seek reassurance that they are able to remain in the foster family. In other cases, it is the parents who realise that they do not want an adolescent back in the family.

The Adoption and Safe Families Act of 1997 (US), s 103(a) which amended the Social Security Act (US), 42 USCS $\S 675(5)(E)$, provides that if a child has been in foster care for the last 15 of the most recent 22 months, or if a court has the child determined to be an abandoned infant, the state has to file a petition to terminate parental rights. That the state has to file an application for termination after 15 months was a compromise. Nicola Atwool "Permanency: what children need" in Nicola Atwool and Tracy Gunn (eds) Care and Protection Orders and CYFS (paper presented to New Zealand Law Society Care and Protection Orders and CYFS Seminar, Wellington, 25 October 2012) at 20. John Triseliotis "Long-term foster care or adoption? The evidence examined" (2002) 7 Child and Family Social Work 23 at 31. See also $A v D$-GSW [1995] NZFLR 241 at 244, where it is stated that the father has become something of a stranger after the children did not have seen him for two years, which is a long time for a small child. adolescence" (2009) 14 Child and Family Social Work 255 at 264. 
In some cases the child cannot be cared for by birth parents due, for example, mental illness or imprisonment. These cases have to be distinguished from the cases mentioned above. The birth parents may have not done something wrong in regard to the child. As already stated, limiting parental rights, especially in these circumstances, must not be seen as a punishment. On the other hand, the child's welfare and thus the child's rights have to be respected. Therefore, it is appropriate to give the court several options to find a suitable solution.

In these cases the court should be given the opportunity to choose between additional guardianship and sole guardianship. This choice depends on the ability of the birth parents to handle the situation and to work together with the new caregivers. Furthermore, the child's welfare has to be the paramount consideration.

Where the court orders additional guardianship this order should be reviewed regularly. Over the time this review should take place at increasing intervals, for example, the first after one year, the second after further two years. On the other hand, the new caregiver should have the possibility to apply for a variation of the additional guardianship order where birth parents are unable to cooperate or become a threat to the security of the placement.

If the court appoints the new caregiver as sole guardian, the rights of the birth parents should be suspended at first. Like the proposed regulation in cases of neglect, the birth parents should have the possibility to improve themselves. Again, after a period of 18 months there must be a decision whether the parental guardianship rights should be removed, if there is no improvement, or whether additional guardianship or a reunification is appropriate.

Especially in cases of mental illness, removal may seem "unfair". However, it has to be kept in mind that the emphasis is on the child. The removal of parental guardianship rights does not mean that birth parents are removed from their child's life. They must have the opportunity to keep contact. ${ }^{549}$ In the end, the child's welfare has to be the deciding factor and it cannot be beneficial for the child's welfare to make no clear decision.

The same applies to an imprisoned birth parent. At a certain point the child has to be placed in a secure environment. In these cases it might be appropriate to vary the 18 months period having regard to the duration of the imprisonment; but even in these cases, welfare has to be paramount.

$549 \quad$ A question which is dealt with below in chapter VII C at 93. 
In some cases a child lives with caregivers due to a private agreement, not necessarily a legal binding one. This can be for the purpose of bridging familial difficulties and often with the expectation that the child will return back after some time. However, where a child lives in such a placement for a long time and considers, for example, the new caregiver as a parent, there should be legal provisions to secure this placement and to give the new caregiver legal responsibility.

Obviously, they can apply for additional guardianship. However, the new caregiver must be given the opportunity to apply for sole guardianship as well. If sole guardianship is granted, parental rights should, again, be suspended and after 18 months of non-improvement be removed. In these cases, of course, cultural issues have to be considered, for example, whāngai.

\section{$5 \quad$ Amending New Zealand statutes}

Another question may be in which legislation new provisions should be included. Several cases have to be distinguished.

Where abuse and neglect occurred, the child was in need of care and protection. Therefore, the Children, Young Persons, and Their Families Act is the statute to be amended for the first three named cases, even though it is a permanent placement and the child may no longer be in need of care and protection pursuant to s 14 .

Amending the Care of Children seems appropriate where the child lives with new caregivers due a private agreement. The child was never in need of care and protection nor in state care in the widest sense.

\section{$6 \quad$ Summary}

The suggestions made in this chapter try to seek a balance between the child's need for security and permanency, the recognition of foster parents as psychological parents and the rights of birth parents. The paramount consideration is the child's welfare. For example, where a reunification would be detrimental it should be waived.

Giving foster parents sole guardianship responsibilities supports the establishment of a secure base. The child can develop a feeling of belonging. In the case of a permanent placement the child often bonds with the caregivers and sees them as psychological parents, especially, when placed in early childhood. The proposal is consistent with the principle in s 5(a) of the 
Care of Children Act: primary responsibility should be with the mother and the father figure. ${ }^{550}$ Furthermore, cooperation between remaining guardians would be simplified. ${ }^{551}$

Giving birth parents the opportunity to show their improvement to retrieve their parental responsibility recognises their human rights. The new family environment can be secured. From a child's point of view it is important to create a secure and stable placement. A time frame is a possibility to achieve this.

An argument against the approach may be that this will lead to birth parents and child drifting even more apart. However, it has to be faced that in the case of a permanent placement reunification is almost impossible. Furthermore, depending on the special circumstances of every case, there is the possibility for birth parents to have contact with their child.

The just proposed amendments contain the possibility to remove parental guardianship rights at an earlier stage compared to the current provisions. As examined, the "grave reasons" test is a too high a threshold considering the child as a person and taking into account the child's welfare.

\section{B Exceptions}

Granting foster parents sole guardianship means that they receive the legal responsibility to care for and bring up a child to the exclusion of someone else. Due to the fact that they are not the biological parents and hence do not have the same legal position as birth parents do, some decisions may be excluded from their legal responsibility. The court should be able to direct the foster parents, for example, regarding religion or cultural issues.

\section{Contact}

A different question is the contact between birth parents and child. Removing or suspending parental guardianship responsibilities does not take away the possibility of having contact with the child. This contact has to be seen independently from the above distinguished cases. Rather, contact depends on the child's welfare. Where contact with birth parents is advantageous, for example, to preserve cultural identity, it should be granted. Duration and manner have to be determined from the child's point of view to support the child's welfare. Therefore, it is important to give the child the chance to formulate his or her views about contact with birth parents. Moreover, also contact with other family members, especially

\footnotetext{
$550 \quad$ Compare Temple v Barr and Holborn HC Wellington CIV-2010-485-000561, 24 August 2010 at [30]; see above chapter V A 2 (b) (i) at 31.

551 See the principle in the Care of Children Act, s 5(c).
} 
grandparents and siblings should be considered. The relationship to the wider family has to be determined, especially in relation to Māori children.

A different question is whether birth parents removed as guardians should be able to obtain information about their child. This could be done by direct contact with foster parents or by another independent person appointed by the court when it is considered as appropriate depending on the parental attitude.

\section{Proceedings}

\section{$1 \quad$ Sole guardianship order}

As already examined to remove or suspend parental responsibilities a court order is needed. ${ }^{552}$ Birth parents must have the possibility to be heard, to appeal against a decision and to be part of a legal proceeding. Therefore, the decision cannot be made by a social worker or police.

\section{$2 \quad$ Challenging court orders}

The court orders made can be challenged. The question is to what extent should birth parents or third parties have the opportunity. To secure the placement, intervention from a third party should be inhibited as much as possible. The legislation should make it more difficult to vary or discharge orders that secure the placement: ${ }^{553}$

It cannot be in the welfare and best interests of children for them to be cut adrift with caregivers in a situation where there is a reasonable risk that a stable placement is undermined through the actions of family members who may not act with the children's welfare at heart.

Where the guardianship rights of birth parents are suspended they should be able to show their improvement. Therefore, they must be given the right to apply to vary the court order within the 18 months period. However, leave of court should have to be obtained. Moreover, they must show a change in circumstances and must prove their improvement. In so far as it can be said that there is a presumption that parents did not improve over the 18 months period, parents should be given the opportunity to adduce evidence to rebut this presumption.

\footnotetext{
$552 \quad$ See above chapter V A 3 (c) (vi) at 53.

$553 \quad E v G$ [parenting orders] 2008 NZFLR 337 at [32].
} 
The White Paper also suggests that "a significant change in circumstances before a care order could be challenged" has to be shown. ${ }^{554}$

After the 18 months period parental guardianship rights will be removed due to the fact that parents did not improve. Focusing on the child means that the opportunity to challenge court orders has to be limited after a certain point in time. Anything else would be detrimental for the child's welfare.

Where parental guardianship rights are removed, the parents have no possibility to challenge this order in order to secure the placement and to give the child a chance to grow up in a safe family environment. This may seem harsh, but parents are given the opportunity to change themselves and to prove their interest in their child. The same applies to other family members. Of course, the intervention in the family relationship should be as narrow as possible and the relationship should be supported. ${ }^{555}$ However, the child's welfare is the paramount consideration.

The 18 months period and the limiting of procedural possibilities to challenge court orders contribute to more continuity in the life of the child. ${ }^{556}$ Due to less interruption the child can develop psychological attachments to the foster family. ${ }^{557}$ The proposals formulated in the Cabinet Paper regarding the Family Court Review are a good step to avoid disruptive attempts. Focusing on the welfare of the child, more precisely the dismissal of applications which are detrimental for the child's welfare, is an appreciated proposal.

\section{$3 \quad$ Resolving disputes}

In cases of additional guardianship birth parents and new caregiver have to work together. As examined, the statutes of New Zealand contain the possibility of obtaining a court direction in cases where they cannot agree on a certain matter. However, there is no legal provision to enforce the court direction. Therefore, the Act should be amended with a regulation providing the possibility to impose a fine where a party does not act according to the court order.

Where there are profound disagreements the court should be able to vary the court order and to change the status of foster parents from additional guardians to sole guardians where this is necessary to support the child's welfare.

\footnotetext{
554 Paula Bennett, Ministry of Social Development "The White Paper for Vulnerable Children" (Wellington, 2012) volume II at 125.

$555 \quad$ See principle in Children, Young Persons, and Their Families Act, s 13(b).

556 See principle in Care of Children Act, s 5(b). As noted, the Family Court Proceedings Reform Bill 2012 contains regulations to limit court proceedings in amending the Care of Children Act 2004 (see clause 27) and the Children, Young Persons, and Their Families Act 1989 (see clause 80). See principle in Children, Young Persons, and Their Families Act, s 13(f)(iii).
} 


\section{E Support}

Where foster parents are granted sole guardianship responsibilities they should still be able to receive financial and other support to secure the upbringing of the child. Foster parents have to deal with vulnerable children. They and the child need support no matter what guardianship provision defines their relationship. Of course, this support depends on the particular circumstances. However, granting sole guardianship cannot be the only reason to stop supporting measures. The Home for Life policy, especially, the package may not be appropriate due the lack to focus on the individual child. A court should not be constrained by a policy; a court should take "seriously its statutory obligation to put in place orders that are in fact in the best interests and welfare of the child." ${ }^{558}$ Moreover, in some cases psychological support for the child to overcome his or her difficult legacy as well as for the foster parents, for example, to remind them of the importance of their role to hold on to their relationship with the child may be necessary.

The White Paper contains an intention to support Home for Life parents where birth parents attempt to disrupt that placement. ${ }^{559}$ Such support should be available even where foster parents do not want to participate in the Home for Life policy. In addition, support should be given not only in the case of disruptive attempts as it is proposed in the White Paper. The child and foster parents may need also psychological and financial support in cases where the birth parents do not try to destabilise the placement.

\section{F Participation}

Finally, but most importantly, the child's views have to be considered. The child must be given a say in proceedings regarding his or her future. The obligation to take the views into account cannot vary from statute to statute. This has to be unified. Of course, the ability to make decisions clear depends on age and maturity. However, this cannot be a reason not to listen. The participation rights of the child should be increased and strengthened.

As already examined, an amendment of the statutes can be the anchoring of a presumption of competence: adults (birth parents, lawyers, judges...) would have to demonstrate that a child is incompetent before the views and wishes can be ignored or overruled.

\footnotetext{
$558 \quad P F M B \vee J J B$ [services orders] [2012] NZFLR 839 at [17], [16].

559 Paula Bennett, Ministry of Social Development "The White Paper for Vulnerable Children" (Wellington, 2012) volume II at 125.
} 


\section{G Other Changes}

Besides the amendments some other changes should be made. The principles set out in s 5 of the Care of Children Act should be applied to define the child's welfare even though the case is dealt with under the Children, Young Persons, and Their Families Act.

The wording of the Children, Young Persons, and Their Families Act should be changed where it still uses the terms of possession and access.

\section{H Summary}

Changing provisions, the child's welfare has to be paramount. A secure and stable placement with positive and ongoing relationships that feels like a "normal family life" should be the long-term goal. Sole guardianship can be a step towards the achievement of this goal. One advantage is also that the legal relationship will not be severed as is the case with adoption. Therefore, it might be more appropriate taking Māori beliefs into consideration.

To summarise the proposed regulations:

1. Where foster parents care for a child on a permanent basis they should become sole guardians:

a. Where the child is the victim of abuse, parental guardianship rights must be removed, and foster parents should become sole guardians.

b. Where the child is the victim of neglect, parental guardianship rights are suspended, and foster parents should become sole guardians.

c. Where the birth parents cannot care for the child for other reasons, the court can chose between additional guardianship and sole guardianship. In the case of sole guardianship parental rights are suspended.

d. Where new caregivers care for the child because of a private agreement, they must be given the opportunity to apply for a sole guardianship order. Parental guardianship rights are suspended.

2. Where parental guardianship rights are suspended, birth parents are given the opportunity to apply for a variation within the following 18 months. Leave has to be granted. Parents have to show their improvement and a change of circumstances. After 18 months without improvement their rights will be removed.

3. Birth parents are given the opportunity to apply for a contact order. Contact depends on the particular circumstances and the child's welfare.

4. Where a court direction is made to resolve a dispute between additional guardians, the court can impose a fine to enforce the direction. 
5. The participation rights of the child have to be strengthened. The child must have a say in proceedings. 


\section{Final Conclusion}

Every child has the right to grow up in a loving family. Where the birth parents are not able to provide this familial environment the child is placed with new caregivers. Even in this placement the child should experience the feeling of belonging and development of personality and be respected as a full member of the family. Unfortunately, these placements are often jeopardised because of disruptive attempts from birth parents and insufficient legal security. To increase stability and security the Ministry of Social Development launched the White Paper for Vulnerable Children which indicates an intention to introduce new guardianship orders. Unfortunately, the White Paper lacks detail. It is intended to curtail parental guardianship powers, but a consideration of the legal consequences, especially for birth parents, is missing as well as procedural rights, for example. Therefore, this dissertation has sought to fill the gap in proposing amendments in order to secure the permanent placement.

In placing a clear and profound emphasis on the child, the welfare of the child has to be the paramount consideration. To provide a secure base for the child to grow up and develop, sole guardianship responsibilities should be given to permanent foster parents. The legal consequences depend on the actual reasons why a child entered foster care. Distinctions have to be made between child abuse and parental mental illness, for example. Furthermore, suggestions are made regarding court proceedings, and the child must be given participation rights in every proceeding.

Giving foster parents sole guardianship to the exclusion of anybody else may secure the permanent placement for the benefit of the child due to the fact of clear responsibility. Why should foster parents become sole guardians? For the same reasons birth parents are: They fulfil the parental role. The relationship between them and the child has to be protected from outside interference. This fastens the responsibility to care for the child on them. ${ }^{560}$

Even where the emphasis is placed on the child, the rights of the birth parents have to be considered. Therefore, birth parents are given the opportunity - except in cases of abuse - to get their responsibilities back. Where they fail to improve the child must be given the chance to experience a family life without interruptions with the new caregivers, who may already have become "mum and dad".

$560 \quad$ Compare Judge Inglis QC in Neho v Duncan [1994] NZFLR 157 at 160; see above chapter V A 2 (c) (ii) at 37. 


\section{Bibliography}

A Cases

$1 \quad$ New Zealand

$A \vee D-G S W[1195]$ NZFLR 241.

A v Ministry of Social Development [Access] [2009] NZFLR 625.

AH $v$ Chief Executive of the Ministry of Social Development FC Timaru FAM-2003-003000172, 28 August 2009.

AHP v RGJ FC Hamilton FAM-2007-019-001613, 29 April 2008.

Atkinson v Atkinson [1990] NZFLR 323.

Auckland District Health Board v AZ and BZ HC Auckland CIV 2007-404-2260, 27 April 2007.

$B v B$ [1978] 1 NZLR 285.

$B v G$ [2002] 3 NZLR 223.

$B v K[2010]$ NZCA 96.

$B v M$ [1997] 3 NZLR 202.

$B v V E(1988) 5$ NZFLR 65.

BP v DGSW [1997] NZFLR 643.

C v M FC Wanganui FP083/086/92, 12 November 1993.

C v W [Custody] [2005] NZFLR 953.

CAS v Chief Executive of the Ministry of Social Development FC Dunedin FAM-2009-012950, 18 July 2011.

CEMSD v M FC Dunedin FAM-2001-012-148, 15 April 2005.

Chief Executive of the Ministry of Social Development v BJG FC Hastings FAM 2009-020447, 19 January 2010.

Chief Executive of the Ministry of Social Development v SK FC Christchurch FAM-2006009-4165, 19 September 2011. 
Child Youth and Family Service v S FC New Plymouth FAM-2005-043-784, 15 November 2006.

CJJ v HJJ HC Auckland CIV-2011-404-2801, 28 September 2011.

Crowther v Green FC Hastings FP020/113/96, 24 June 1998.

$D v W(1995) 13$ FRNZ 336.

Department of Child, Youth and Family Services $v$ GDB FC Nelson FAM-2003-009-4314, 02 November 2005.

$D-G S W v B$ HC Palmerston North M 42/97, 18 August 1997.

Director-General of Social Welfare v G-S (1995) 14 FRNZ 23.

Director-General of Social Welfare v L [1989] 2 NZLR 314.

Director-General of Social Welfare v R (1997) 16 FRNZ 357.

DSW v R DC Auckland CYPF 004/53/93, 22 February 1994.

$D S W v T$ [1998] NZFLR 177.

Ev G [parenting orders] 2008 NZFLR 337.

Ev M HC Wellington M 316/79, 13 September 1979.

FMHM \& Anor v JJMP \& Ors FC Grisborne FAM 2010-016-121, 25 February 2011.

$G v$ Chief Executive of the Ministry of Social Development FC Rotorua FAM-1999-063-15, FAM-2002-063-638, 22 May 2007.

$G v G[1978] 2$ NZLR 444.

GFS v ES [2007] NZFLR 495.

Hawthorne v Cox [2008] 1 NZLR 409.

In the matter of AHRJ [2005] NZFLR 49.

In the matter of $C$ [2003] NZFLR 769.

$J G v$ Chief Executive of the Ministry of Social Development FC Rotorua FAM-1999-063-15, FAM-2002-063-638, 22 May 2007.

$J M N v R V G$ [2008] NZFLR 111. 
JS v CR HC Auckland CIV-2011-404-002711, 20 September 2011.

$K \vee B$ [1991] NZFLR 168.

$K v G$ [2004] NZFLR 1105.

Kacem v Bashir [2011] NZLR 1.

Mv O FC Te Awamutu FAM-2005-072-185 29, June 2007.

Ministry of Social Development v C FC North Shore FAM-2005-004-001166, 19 February 2010.

Ministry of Social Development v C-P F FC Kaikohe FAM-2008-027-000351, 26, 27 May 2011.

Moyle v Child, Youth and Family FC Papakura CYPF055/4-6/96; 21/98, 6 August 2002.

$N v C-D$ [2009] NZFLR 193.

Neho v Duncan [1994] NZFLR 157.

PED v MHB [Whangai: Final Parenting Order] [2012] NZFLR 35.

PFMB v JJB [services orders] [2012] NZFLR 837.

Pita v Putahi FC Rotorua FP063/075/98, 29 September 2000.

PJKW v DAR [Guardianship] [2006] NZFLR 946.

$R v R$ FC Palmerston North FAM-2001-054-723, 17 August 2005.

Re B (children) [1992] NZFLR 726.

Re Children FC Napier CYPF 041/002/89, 13 June 1990.

Re D (An infant) [1971] NZLR 737.

Re L-S FC Christchurch CYPF 009/109-11/92, 18 August 1998.

Re T(1999) 19 FRNZ 11.

$\operatorname{Re} T$ [1982] 2 NZLR 662.

Re the Five M Children [2004] NZFLR 337.

Re the L children FC Papakura CYPF 055/15-20/94, 7 December 2001. 
Re the P Children (No 2) (1992) 9 FRNZ 93.

Rivers v Carian FC Palmerston North FP054/327/97, 23 August 2002.

$S v C$ FC Marton FP 034028 94, 28 April 1995.

$S v D-G S W[1991]$ NZFLR 89.

$S$ v D-GSW FC Palmerston North CYPF (054) 7/90, 6 December 1990.

$S v E(1981) 1$ NZFLR 73.

Skegdwell v Ewington [1992] NZFLR 614.

Tanner v Edgill [2008] NZFLR 262.

Taylor v Wilson, Wilson and Wilson FC Hastings FP 020/172/96, 30 April 1998.

Temple v Barr and Holborn HC Wellington CIV-2010-485-000561, 24 August 2010.

TTH v JTAH [Parenting order] [2011] NZFLR 369.

$W v D-G S W(1991) 7$ FRNZ 450.

Wise v Wise FC Hamilton FP019/316/01, 5 May 2003.

Wright v Wright [1984] 1 NZLR 366.

\section{England}

$J$ and Another $v C$ and Others [1969] 1 All ER 788.

Gillick v West Norfolk and Wisbech Area Health Authority [1986] 1 AC 112, [1985] 3 All ER 402.

Hewer v Bryant [1969] 3 All ER 579 at 582.

Re S (Adoption order or special guardianship order) [2007] 1 FLR 819.

Re MJ (Adoption order or special guardianship order) [2007] 1 FLR 691.

Re J (Adoption order or special guardianship order) [2007] 1 FLR 507. 
$3 \quad$ United States of America

DJM v DM (In re SBR-M) 2009 WY 22 = In the Interests of SRB-M (2009) 201 P3d 1115.

Carla R v Tim H(In re DJ) (2004) 682 Nw 2d 238.

B Legislation

$1 \quad$ New Zealand

Care of Children Act 2004.

Children, Young Persons, and Their Families Act 1989.

Education Act 1989.

Crimes Act 1961.

Summary Offences Act 1981.

Marriage Act 1955.

Civil Union Act 2004.

Guardianship Act 1968.

Family Court Proceedings Reform Bill 2012.

\section{United Kingdom}

Adoption and Children Act 2002 (UK).

Children Act 1989 (UK).

$3 \quad$ United States of America

Adoption and Safe Families Act of 1997 (US).

Social Security Act 42 USCS. 


\section{$4 \quad$ United Nations}

United Nations Convention on the Rights of the Child GA Res 44/25 (1989).

United Nations Statute of the International Court of Justice (1946).

\section{Other Official Materials}

Paula Bennett, Ministry of Social Development "Every child thrives, belongs, achieves - Ka whai orange, ka whai wāhi, ka whai traumata ia tamaiti” (Wellington, 27 July 2011).

Paula Bennett, Ministry of Social Development "The White Paper for Vulnerable Children" (Wellington, 2012) volume I.

Paula Bennett, Ministry of Social Development "The White Paper for Vulnerable Children" (Wellington, 2012) volume II.

Law Commission "Report 65: Adoption and its Alternatives: A Different Approach and a New Framework" (Law Commission, Wellington, September 2000).

Ministry of Social Development "Summary of Submissions on the Green Paper for Vulnerable Children".

Ministry of Social Development "Executive Summary of Submission on the Green Paper for Vulnerable Children” (Ministry of Social Development, Wellington, August 2012).

Ministry of Social Development "Green Paper for Vulnerable Children - Complete Summary of Submissions" (Ministry of Social Development, Wellington, August 2012).

Secretary of State for Health by Command of Her Majesty "Adoption: A New Approach: A White Paper (London, December 2000) at 28-29; Claire Sanders "Safety net?" (2009) 159 NLJ 1623.

UNICEF Rights of the Child (3rd ed, UNICEF, Geneva, 2007). 


\section{Books/ Monographs}

Kirstin Bernard and Mary Dozier "Adoption and Foster Placement” in Marshall M Haith and Janette B Benson (eds) Encyclopedia of Infant and Early Childhood Development (Academic Press, San Diego, 2008).

Trevor Buck, Alisdair A Gillespie, Lynne Ross and Sarah Sargent International Child Law (2nd ed, Routledge, Oxon and New York, 2011).

Department of Child, Youth and Family Services Children in care: Permanency policy (unpublished, Wellington, 2006).

Michael Freeman "Article 3 The Best Interests of the Child" in André Alen, Hohan Vande Lanotte, Eugeen Verhellen, Fiona Ang, Eva Berghmans and Mieke Verheyde (eds) A Commentary on the United Nations Convention on the Rights of the Child (Martinus Nijhoff Publishers, Leiden, 2007).

Rachel Hodgkin and Peter Newell Implementation Handbook for the Convention on the Rights of the Child (3rd ed, UNICEF, Geneva, 2007).

Allison James and Adrian James Key Concepts in Childhood Studies (Sage Publications Ltd, London, 2008).

Gerison Lansdown “Children's rights” in Berry Mayall (ed) Children's childhood: Observed and Experienced (The Falmer Press, London, 1994).

Gerison Lansdown The Evolving Capacities of the Child (Save the Children, UNICEF, Florence, 2005).

R MacKay "Conceptions of children and models of socialisation" in H P Dreitzel (ed) Childhood and Socialization (Collier-Macmillam, London, 1973).

Joan Metge and Jacinta Ruru "Kua Tutū Te Puehu, Kia Mau: Māori Aspirations and Family Law Policy" in Mark Henaghan and Bill Atkin (eds) Family Law Policy in New Zealand (3rd ed, LexisNexis, Wellington, 2007).

Robert W Plant and Lesley Siegel "Children in Foster Care: Prevention and Treatment of Mental Health Problems" in Thomas P Gullotta and Gary M Blau (eds) Family influences in childhood behavior and development (Routledge Taylor \& Francis Group, New York, 2008).

Alan Prout and Allison James "A New Paradigm for the Sociology of Childhood? Provenance, Promise and Problems" in Allison James and Alan Prout (eds) Constructing and Reconstructing Childhood: Contemporary Issues in the Sociological Study of Childhood (2nd, Falmer Press, London, 1990). 
I M Schwartz, S Kinnevy and T White "Adoption and Foster Care: United States" in Neil J Smelser and Paul B Baltes (eds) International Encyclopedia of the Social \& Behavioral Sciences (Pergamon, Oxford, 2001).

Anne B Smith "Children's rights: An overview" in Anne B Smith, Megan Gollop, Kate Marshall and Karen Nairn (eds) Advocating for children: International Perspectives on Children's Rights (University of Otago Press, Dunedin, 2000).

\section{E Journal Articles}

Gunvor Andersson "Children in permanent foster care in Sweden" (1999) 4 Child and Family Social Work 175.

Nicola Atwool "Participation in Decision-making: The Experience of New Zealand Children in Care" (2006) 3 Child Care in Practice 259 - 267.

Andrew Bainham “Permanence for Children: Special Guardianship or Adoption?” [2007] The Cambridge Law Journal 520.

Kathleen S Bean "Reasonable Efforts: What state courts think" (2005) 36 U Tol L Rev 321.

Kathleen S Bean "Aggravated Circumstances, Reasonable Efforts, And AFSA" [2009] Boston College Third World Law Journal 223.

Judy Cashmore "What can we learn from the US experience on permanency planning?" (2001) 15 Australian Journal of Family Law 1.

Marie Connolly “A kinship care literature review” (2003) 25 Social Work Now 24.

Allan Cooke "Permanency for children: why permanently placed children need ongoing support, and how to deliver that support" (2008) 6 NZFLJ 37.

Allan Cooke "Contact Issues for children who have been permanently placed out of their birth families" (2009) 6 NZFLJ 176.

Stephen Coyle "Permanency policy: children in care" (2008) 6 NZFLJ 45.

Gary S Cuddeback "Kinship family foster care: a methodological and substantive synthesis of research" (2004) 26 Children and Youth Services Review 623.

James G Dwyer 'Parent's Self-Determination and Children's Custody: A New Analytical Framework for State Structuring of Children's Family Life” (2012) 54 Ariz L Rev 79.

John Eekelaar "The Interests of the Child and the Child's Wishes" The Role of Dynamic Self-determinism" (1994) 8 Int'l JL \& Fam 42.

Robert H George "Principles relevant to child's welfare and best interests" (2011) 7 NZFLJ 26.

Carrie Jefferson Smith, Claire Rudolph and Peter Swords "Kinship Care: Issues in Permanency Planning” (2002) 24 Children and Youth Services Review 175. 
N A Johnston and R J Hooker "The law relating to foster care in New Zealand (I)" [1985] NZLJ 160.

N A Johnston and R J Hooker "The law relating to foster care in New Zealand (II)" [1985] NZLJ 201.

Emily Kernan and Jennifer E Lansford "Providing for the best interests of the child?: The Adoption and Safe Families Act of 1997” (2004) 25 Applied Developmental Psychology 523.

Virginia A Leary "The Social and Economic Rights of the Child" (1995) 17 Law \& Pol'y 353.

Gary B Melton "The Right to a Family Environment for 'Children Living in Exceptionally Difficult Conditions"” (1995) 17 Law \& Pol'y 345.

Jill Theresa Messing "From the child's perspective: A qualitative analysis of kinship care placements" (2006) 28 Children and Youth Services Review 1415.

Christine Mullan, Siobán McAlister, Fiona Rollock and Lelia Fitzimons “"Care Just Changes Your Life': Factors Impacting upon the Mental Health of Children and Young People with Experiences of Care in Northern Ireland" (2007) 13 Child Care in Practice 417.

Julia Nelson “Special Guardianship Orders - An Introduction” [2005] Fam Law 573.

Cas O’Neill "Parenting Troubled Children” (2004) 10 Journal of Family Studies 206.

Celeste Pagano "Recent legislation: Adoption and foster care" (1999) 36 Harv J on Legis 242.

Patrick Parkinson "Child Protection, Permanency Planning and Children's Right to Family Life" (2003) 17 International Journal of Law Policy and the Family 147.

Gabrielle Jan Posner "Some fascinating facts about special guardianship orders" [2007] Fam Law 423.

Gillian Schofield and Mary Beek "Providing a secure base: parenting children in long-term foster family care" (2005) 7 Attachment \& Human Development 3.

Gillian Schofield and Mary Beek "Growing up in foster care: providing a secure base through adolescence" (2009) 14 Child and Family Social Work 255.

Claire Sanders “Safety net?” (2009) 159 NLJ 1623.

Gillian Schofield and Mary Beek "Providing a secure base: Parenting children in long-term foster family care" (2005) 1 Attachment \& Human Development 3.

Anne B Smith "Interpreting and supporting participation rights: Contributions from sociocultural theory" (2002) 10 The International Journal of Children's Rights 73.

Susan Smith "Protection and identity: Finding the right balance to belong" (2012) 7 NZFLJ 124.

K Chase Stovall and Mary Dozier "Infants in Foster Care: An Attachment Theory Perspective" [1998] Adoption Quarterly 55. 
Stephan A Talmadge "Who Should Determine What Is Best for Children in State Custody Who Object to Psychotropic Medication?” (2006) 15 Ann Health L 183.

John Triseliotis „Long-term foster care or adoption? The evidence examined” (2002) 7 Child and Family Social Work $22-33$.

Rachel Venier "Parental rights and the best interests of the child: Implications of the Adoption and Safe Families Act of 1997 on domestic violence victim's rights" (2000) 8 Am UJ Gender Soc Pol'y \& L 517.

Lillian Wan "Parents killing parents: Creating a presumption of unfitness" (1999) 63 Alb L Rev 333.

Deborah Yates "Sink or swim: leaving care in New Zealand" (2001) 16 Social Policy Journal of New Zealand 155.

\section{F $\quad$ Looseleaf Texts}

Brookers Family Law (online looseleaf ed, Brookers).

Family Law Service (online looseleaf ed, LexisNexis).

\section{G Internet Materials and Others}

Child Welfare League of America Summary of the Adoption and Safe Families Act of 1997 <http://www.cwla.org/advocacy/asfapl105-89summary.htm>.

Child, Youth and Family "Permanent Care and creating a Home for Life" (3 April 2012) <www.practicecentre.cyf.govt.nz>.

Child, Youth and Family "Returning children safely home" www.practicecentre.cyf.govt.nz>.

Child, Youth and Family "Securing a bright and safe future in a home for life" <www.practicecentre.cyf.govt.nz>.

Child, Youth and Family "Supporting young people to return home safely" <www.practicecentre.cyf.govt.nz>.

Child, Youth and Family "Use of Legal Orders to secure a home for life" (May 2011) <www.practicecentre.cyf.govt.nz>.

Committee on the Rights of the Child Report on the fortieth session CRC/C/153 (2005).

Oxford English Dictionary (2nd ed, 1989, online ed). 
The National Archives "Section 115: Special Guardianship" Adoption and Children Act 2002: <www.legislation.gov.uk/ukpga/2002/38/notes/division/4/2/5>.

US Legal <guardianship.uslegal.com/permanent-guardianship>.

\section{H Speeches, Papers and Reports}

Nicola Atwool "Permanency: what children need" (New Zealand Law Society Care and Protections Orders and CYFS Seminar, Wellington, 25 October 2012).

Nicola Atwool "Permanency: what children need" in Nicola Atwool and Tracy Gunn (eds) Care and Protection Orders and CYFS (paper presented to New Zealand Law Society Care and Protection Orders and CYFS Seminar, Wellington, 25 October 2012).

Report from the Children's Forum published in Anne B Smith "Children's rights: An overview" in Anne B Smith, Megan Gollop and Karen Nairn (eds) Advocating for children: International Perspectives on Children's Rights (University of Otago Press, Dunedin, 2000).

Tracy Gunn "Review of practice relating to representing clients in proceedings under the Children, Young Persons, and Their Children Act 1989" (New Zealand Law Society Care and Protections Orders and CYFS Seminar, Wellington, 25 October 2012).

Tracy Gunn "Review of practice relating to representing clients in proceedings under the Children, Young Persons, and Their Children Act 1989" in Nicola Atwool and Tracy Gunn (eds) Care and Protection Orders and CYFS (paper presented to New Zealand Law Society Care and Protection Orders and CYFS Seminar, Wellington, 25 October 2012).

United Nations Committee on the Rights of the Child "Report on the Fortieth Session 12-30 September 2005" (Geneva, 17 March 2006). 


\section{Glossary of Māori Terms}

Hapū kinship group, clan, tribe, sub-tribe

Iwi extended kinship group, tribe; often refers to a large group of people descended from a common ancestor

Pākehā N New Zealander of European descent

Taonga treasure, anything prized; applied to anything considered to be of value

Whakapapa genealogy, genealogical table, lineage, descent

Whānau extended family, family group

Whāngai to feed, to bring up, foster; foster child, adopted child; it is a customary practice

Source: Te Aka, Māori-English, English-Māori Dictionary (online ed) <www.maoridictionary.co.nz> . 